\title{
Utilization Risk Assessment and Thermal Conductivity Testing for the Low Temperature Geothermal Play Fairway Analysis for the Appalachian Basin
}

Kelydra Welcker

Follow this and additional works at: https://researchrepository.wvu.edu/etd

\section{Recommended Citation}

Welcker, Kelydra, "Utilization Risk Assessment and Thermal Conductivity Testing for the Low Temperature Geothermal Play Fairway Analysis for the Appalachian Basin" (2016). Graduate Theses, Dissertations, and Problem Reports. 6936.

https://researchrepository.wvu.edu/etd/6936

This Thesis is protected by copyright and/or related rights. It has been brought to you by the The Research Repository @ WVU with permission from the rights-holder(s). You are free to use this Thesis in any way that is permitted by the copyright and related rights legislation that applies to your use. For other uses you must obtain permission from the rights-holder(s) directly, unless additional rights are indicated by a Creative Commons license in the record and/ or on the work itself. This Thesis has been accepted for inclusion in WVU Graduate Theses, Dissertations, and Problem Reports collection by an authorized administrator of The Research Repository @ WVU. For more information, please contact researchrepository@mail.wvu.edu. 


\title{
Utilization Risk Assessment and Thermal Conductivity Testing for the Low Temperature Geothermal Play Fairway Analysis for the Appalachian Basin
}

\author{
Kelydra Welcker \\ Thesis submitted to \\ Benjamin M. Statler College of Engineering and Mineral Resources \\ at West Virginia University \\ in the partial fulfillment of the requirements for the degree of \\ Master of Science \\ in \\ Chemical Engineering
}

Dr. Brian J. Anderson, Ph.D., Chair

Dr. Charter D. Stinespring, Ph.D.

Dr. Hema J. Siriwardane, Ph.D.

Department of Chemical Engineering

Morgantown, West Virginia

2016

Keywords: low-temperature, direct use, geothermal, Fairway Analysis, Appalachian Basin, thermal conductivity

Copyright 2016 Kelydra Welcker 


\title{
Abstract \\ Utilization Risk Assessment and Thermal Conductivity Testing for the Low Temperature Geothermal Play Fairway Analysis for the Appalachian Basin
}

\author{
Kelydra Welcker
}

In order to alleviate the large carbon footprint of fossil fuel technology, renewable energy has begun to gain momentum with consumers and industries alike. Geothermal energy has the benefit of providing a reliable energy source with only $5 \%$ of the carbon dioxide emissions of fossil fuels, as well as provide a means of carbon sequestration. The application for this energy source is highly dependent on several factors, including reservoir characteristics, temperature, and regional demand. High temperature systems $\left(>150^{\circ} \mathrm{C}\right)$ are best suited for electricity production, while low and medium temperature reservoirs $\left(<90{ }^{\circ} \mathrm{C}\right.$ and $90-150{ }^{\circ} \mathrm{C}$, respectively) may be better suited for direct use applications, such as manufacturing purposes or district heating and cooling for commercial and residential areas.

Enhanced, or engineered, geothermal systems (EGS) may provide a means to take advantage of geothermal reservoirs with lower available temperatures. To determine the efficacy of EGS technology in eastern United States, a play fairway analysis was performed on the Appalachian basin. Risk factors examined include thermal resource quality, natural reservoir quality, induced seismicity, and utilization opportunities, which is a focus of this work. Levelized cost of heat, or $\mathrm{LCOH}$, was used to provide a comparison of factors, such as combination of capital costs, operation and maintenance costs, and performance and fuel costs. To determine $\mathrm{LCOH}$, commercial, residential, and infrastructure data were collected from the US Census and fed into GEOPHIRES, a program that uses surface piping, heat exchange equipment (residential and/or commercial), operations, upfront capital cost, and maintenance costs over the lifetime of a 30year project. The impact of industrial demand on $\mathrm{LCOH}$, such as process heating and cooling and HVAC, for dairy, wood drying, and paper mills were also examined.

Heat flow estimates are equally important in the selection of potential geothermal sites. Estimation of the temperature-at-depth uses heat flow, which is dependent on factors including geothermal gradient and thermal conductivities. Thermal conductivity is a function of depth and position, and for some models is calculated as a weighted average based on thicknesses of lithographic layers. Obtaining actual thermal conductivities can be challenging, and often require the use of databases to predict the geographic variation. For this project, thermal conductivities from Marion County well \#244 rock cuttings were found using a portable electronic divided bar (PEDB) system and were compared to COSUNA estimates to assess the current model method. 


\section{Acknowledgements}

I would like to thank my research advisor, Dr. Brian Anderson for allowing me the opportunity to broaden my academic knowledge in the field of geothermal energy and work on such a ground breaking project. I am grateful for his patience with my numerous questions and equipment difficulties.

To my committee members, Dr. Charter D. Stinespring and Dr. Hema J. Siriwardane, I would like to express my gratitude to for their constructive remarks and suggestions on this manuscript.

In addition, I would like to share my deepest appreciation to the Appalachian Basin Geothermal Play Fairway Analysis team: Teresa Jordan, Frank Horowitz, Jery Stedinger, Jefferson Tester, Erin Camp, Calvin Whealton, and Jared Smith from Cornell University and also to Maria Richards, Cathy Chickering Pace, Matt Hornbach, Christine Ferguson, Rahmi Bolat, Maria Beatrice Magnani from Southern Methodist University. Thank you making me feel welcome to the team, and for sharing your passion for geothermal exploration.

Also, a special thank you to Timothy Reber, graduate from Cornell University, and Dr. Zachary Frone, graduate from Southern Methodist University, who were kind enough to take time in their evenings to explain coding and methodologies, and Dr. Xiaoning He, fellow Mountaineer and recent graduate of WVU, who taught me the finer points of ArcGIS.

Finally, I would like to express my love and appreciation to my friends and family that have made Morgantown, and West Virginia University, my home for the last several years. Thank you for your continued support and encouragement! 


\section{Table of Contents}

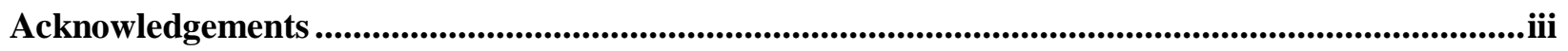

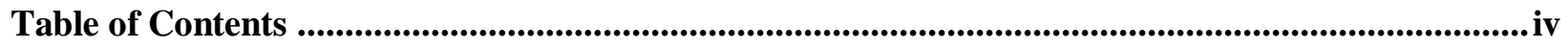

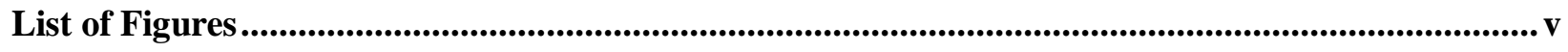

List of Tables .............................................................................................................................................. vi

List of Nomenclature and Variables ...........................................................................................

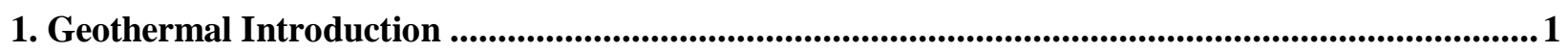

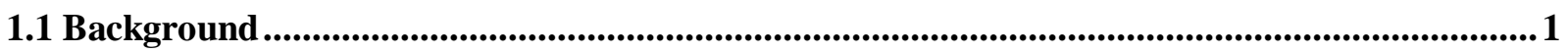

1.2 Geothermal Energy ..........................................................................................................................2

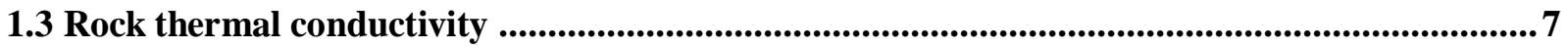

2. Features Influencing Geothermal Expansion ......................................................................................8

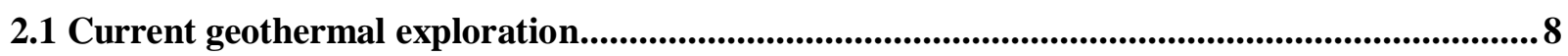

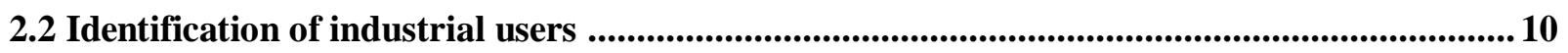

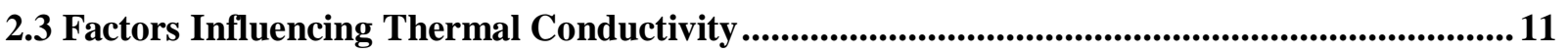

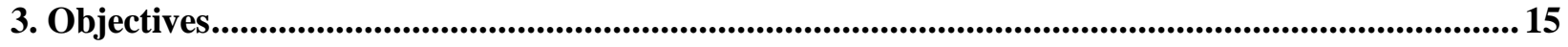

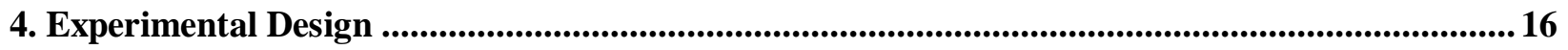

4.1 Utilization Risk for Play Fairway Analysis ................................................................................... 16

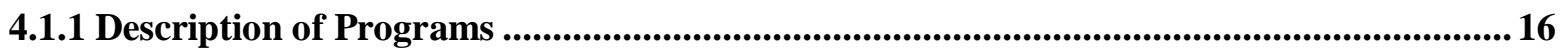

4.1.2 Overview of Residential Levelized Cost of Heat Method ................................................. 18

4.1.3 Final Considerations and Program Outputs ..................................................................21

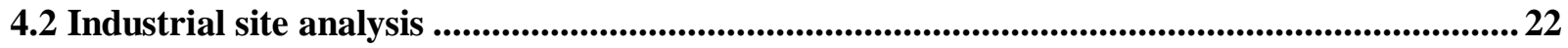

4.3 Thermal conductivity analysis of well data ...................................................................................26

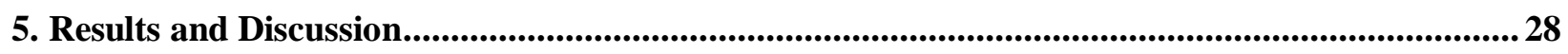

5.1 Impact of Industrial Demand and Existing Infrastructure Credits on LCOH ......................28

5.2 Thermal Conductivity Findings ........................................................................................................ 31

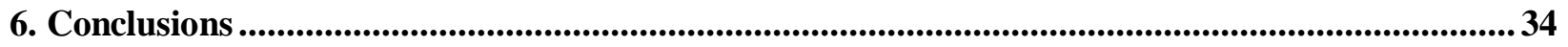

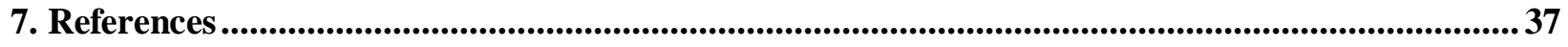

Appendix A - Standard Operating Procedure for HDR Portable Electronic Divided Bar (PEDB). 42

Appendix B - Main GEOPHIRES file ...............................................................................................................45

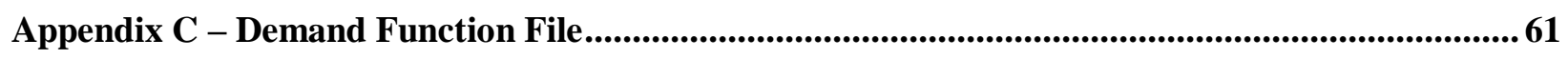

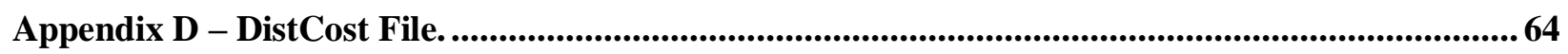

Appendix E - Flow Calculation File ........................................................................................................72 72

Appendix F - Make Input File. .............................................................................................................. 76 


\section{List of Figures}

Figure 1. Projected world consumption by fuel (quadrillion BTU) .........................

Figure 2. Breakdown of 2010 global geothermal energy production by country................3

Figure 3. Lindal diagram illustrating the temperature requirements for potential industrial applications of direct thermal use of geothermal

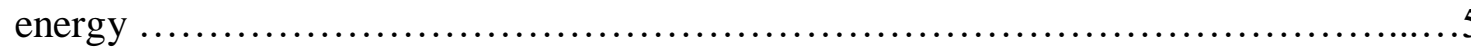

Figure 4. Schematic of a geothermal power plant with one injection well (downward blue arrow) and two production wells (upward gradient arrows)...........6

Figure 5. Heat flow map showing areas geothermal hot spots across of the United States.........9

Figure 6. Diagram illustrating the primary and secondary effects of grain size on thermal

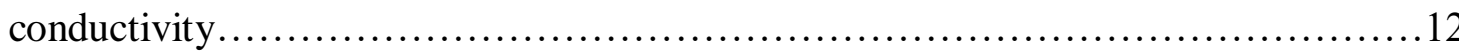

Figure 7. Comparison of thermal conductivity measured on intact cores with fragment determinations after the cores were crushed................................... 14

Figure 8. Overlay of Appalachian Basin over the three states of interest (WV, PA, NY).......19

Figure 9. Industries located in Census 'places' within the Appalachian Basin tristate area......23

Figure 10. Illustration of the PEDB and hollow cell containing sample setup.................26 


\section{List of Tables}

Table 1. Temperature ranges for industries considered for this analysis .......................22

Table 2. Comparison of grain size of limestone samples to grain sizes found with Marion County \#244 well samples........................................................... 28

Table 3. Top ten West Virginia census places with lowest base case $\mathrm{LCOH}$ with populations greater than 4000, compared to impact on LCOH of adding manufacturing demand...29

Table 4. Top ten New York census places with lowest base case LCOH with populations greater than 4000, compared to impact on $\mathrm{LCOH}$ of adding manufacturing demand ...........30

Table 5. Top ten Pennsylvania census places with lowest base case LCOH with populations greater than 4000, compared to impact on $\mathrm{LCOH}$ of adding manufacturing demand....30

Table 6. Analysis of the impact of grain size on thermal conductivity........................31

Table 7. Comparison of existing thermal conductivity estimates (COSUNA and Frone) to thermal conductivities performed on Marion County \#244well rock cuttings. .32 


\section{List of Nomenclature and Variables}

$\begin{array}{ll}\text { BHT } & \text { Bottom Hole Temperature } \\ \text { EGS } & \text { Enhanced (or engineered) geothermal system } \\ \text { EIA } & \text { Energy Information Administration } \\ \text { LCOH } & \text { Levelized Cost of Heat (reported in } \$ \text { /MMBTU) } \\ \text { \$/MMBTU } & \text { million BTU (British Thermal Unit). } \\ \text { MBTU } & \text { Thousand British Thermal Units }(1 \mathrm{MBTU}=1000 \mathrm{BTU}) \\ \text { MMBTU } & \text { Million British Thermal Units }(1 \mathrm{MMBTU}=1,000 \mathrm{MBTU}=1,000,000 \\ & \text { BTU) } \\ \text { MWth } & \text { Thermal Mega-Watts (1 MWth } \approx 3.412 \mathrm{MMBTU} / \mathrm{hr}) \\ \text { COSUNA } & \text { Correlation of Stratigraphic Units of North America } \\ \text { HVAC } & \text { Heating, ventilation, and air conditioning } \\ \text { GEOPHIRES } & \text { Geothermal Energy for Production of Electricity and Heat Economically } \\ & \text { Simulated (software package) } \\ \text { GWth } & \text { Thermal Giga-Watts (1 GWth = 1000 MWth) } \\ \text { PEDB } & \text { portable electronic divided bar (tool for measuring thermal conductivity) } \\ \text { NY } & \text { New York } \\ \text { PA } & \text { Pennsylvania } \\ \text { WV } & \text { West Virginia } \\ \gamma & \text { thermal conductivity (units: watts per meter Kelvin or W/m-K) }\end{array}$




\section{Geothermal Introduction}

\subsection{Background}

As energy consumption for the United States is projected to increase, new sources of energy are in high demand [1]. Projected estimated fuel prices can be difficult to model due to multiple factors, including drilling costs, finite resource availability, and demand, both domestic and global [1,2]. According to the Energy Information Administration (EIA) in 2013, the global energy consumption is expected to increase 56\%, with fossil fuels continuing to dominate the market at $80 \%$ by 2040 (Figure 1) [3,4].

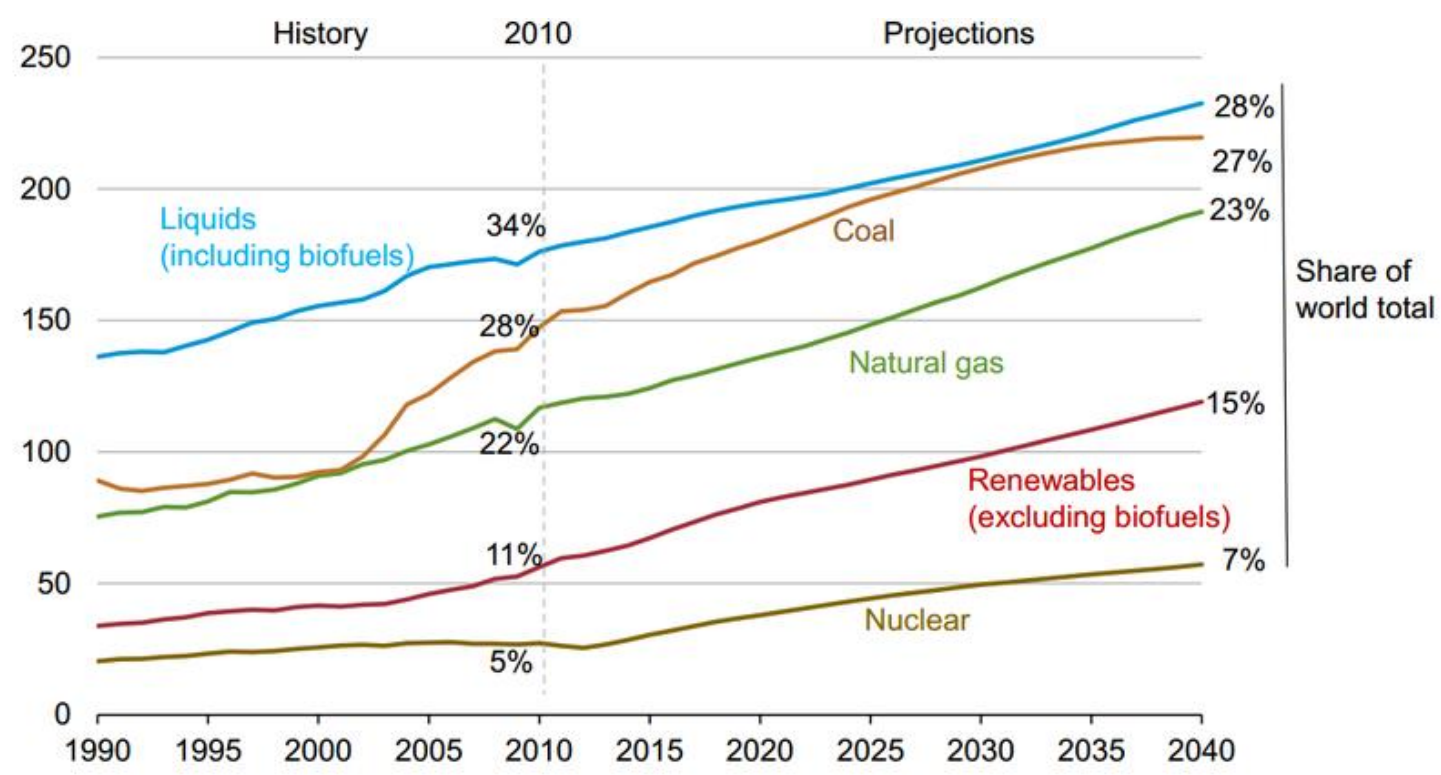

Figure 1. Projected world consumption by fuel (quadrillion BTU/yr) [4]

In addition to the production of pollution and the risk of fuel shortages, governmental legislation is forcing businesses to face the daunting task of improving efficiencies of current technology, or find alternative fuels. The Paris climate conference in December of 2015 had representatives from 195 countries discuss and adopted the legally binding global climate deal. In this plan, each country would do its part to limit global warming to below $2^{\circ} \mathrm{C}$ by 2020. [5] 
Countries and governments are considering taxing industries in order to meet these restrictions. This gives businesses a narrow window of time to adapt current methodologies to meet these criteria.

As of now, modern gas-fired combined cycle thermal power plants can reach efficiencies of $60 \%$, meaning $60 \%$ of the heat energy created by fuel combustion is converted to electricity and the remainder is lost, often referred to as "wasted" heat [5,6]. Combined heat and power (CHP), or cogeneration, plants can obtain efficiencies up to 60 to $90 \%$ by taking advantage of this "wasted" heat for space heating or some industrial processes [6,7]. Fossil fuels are a high energy source and are capable of generating temperatures well above $2000{ }^{\circ} \mathrm{C}$, depending on fuel-air composition, combustor design, and other factors [8]. The work-producing potential, or exergy, of fossil fuels meet the extreme energy demands of systems like gas turbines, which are designed for high efficient energy conversion. The downgrading of such a high heat generating process for low-temperature needs, such as space and water heating, results in a further loss of exergy. A reevaluation of current technology by matching the thermal needs of processes would greatly reduce long term economic and environmental costs.

\subsection{Geothermal Energy}

Renewable energy sources may provide the solution to these global challenges. As seen in Figure 1, renewable energy, such as geothermal and solar power, is estimated to increase at a rate of $2.5 \%$ per year $[3,4]$. When compared to fossil fuel plants, geothermal systems produce only $5 \%$ of the carbon dioxide emissions and have been shown by archeological studies to have been used as early as 10,000 years ago by Paleo-Indians for warmth, cleansing, and minerals $[9,10,11]$. The first commercial geothermal power plant producing power to the U.S. utility grid was constructed in the 1960's at The Geysers in California. Producing $11 \mathrm{MW}_{\mathrm{e}}$ of net power, it 
was a pioneering method in a previously untapped field [10]. In 2010, the United States has increased its installed geothermal capacity to $3.4 \mathrm{GW}_{\mathrm{e}}$, approximately $29 \%$ of the worldwide online installed geothermal power capacity $\left(11.4 \mathrm{GW}_{\mathrm{e}}\right)$ [12]. During this time, 24 countries have been producing electricity from geothermal resources (Figure 2). Iceland is perhaps one of the most notable countries taking advantage of geothermal energy, specifically for direct use applications. Approximately $95 \%$ of the buildings are heated using geothermal energy [12].

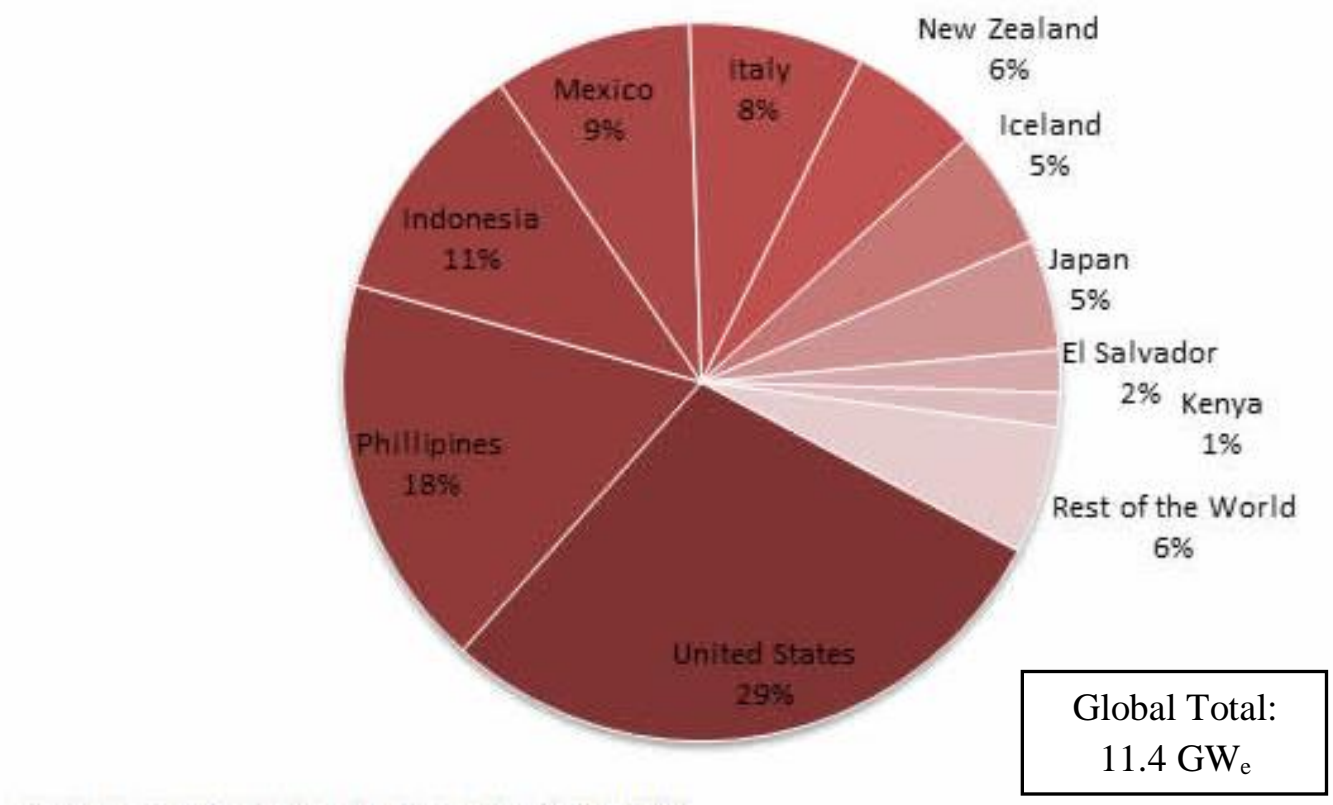

Source: Source:International Geothermal Association, 2010

Figure 2. Breakdown of 2010 global geothermal energy production by country. [11,12]

Expansion of geothermal applications has proved to be challenging. Drilling is an expensive factor, resulting in high installation costs which tend to discourage potential users. Identifying the features of the geothermal reservoir can difficult to obtain, and since it is these properties that will govern the future function, being able to accurately model the reservoir is key. Geothermal energy can be classified in different ways, including reservoir characteristics and temperature, which include hydrothermal systems, conductive systems and deep aquafers $[7,10,11]$. 
Hydrothermal systems are often defined as containing liquid and vapor, while conductive systems are usually just hot rock and magma, and deep aquifers are often found at depths greater than 3 kilometers, contain circulating fluids in porous media [11]. In addition, temperature of the potential geothermal system can be split into low $\left(<90{ }^{\circ} \mathrm{C}\right)$, medium $\left(90-150{ }^{\circ} \mathrm{C}\right)$, and high $(>150$ $\left.{ }^{\circ} \mathrm{C}\right)$ temperature sources $[15,16,17]$. High temperature geothermal locations are frequently used for electricity production, while low temperature locations are more often utilized for direct-use applications, ranging from district heating, best illustrated in Iceland and France, to greenhouse and aquaculture or even major industrial applications, like food processing or wood drying $[8,10,12,13,15]$

Heat pumps, or ground source heat pumps (GSHP), are systems that take advantage of the moderate temperatures in the ground to heat and cool a home or business throughout the year. Direct use geothermal systems recover more energy from the extracted fluid than the straight conversion of heat to electricity, with direct use converting $90 \%$ versus hydrothermal systems converting $10 \%$ of its resources to electricity $[18,19]$. A Lindal diagram of the required temperatures show that low geothermal systems would provide adequate source of heat for a large portion of the applications in residential, commercial and some industrial operations [19]. 


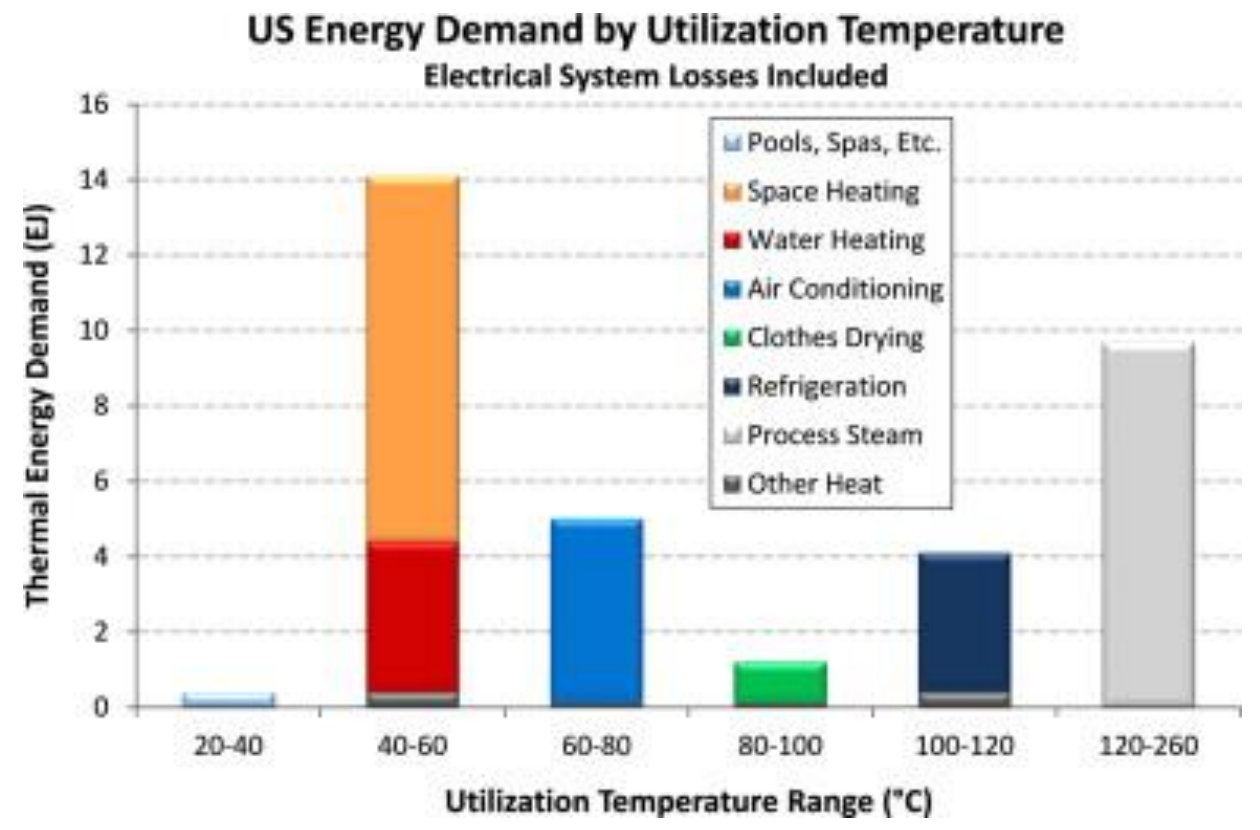

Figure 3. Lindal diagram illustrating the temperature requirements for potential industrial applications of direct thermal use of geothermal energy [19].

Fox et al (2011) determined that nearly one third of the United States energy consumption is based on processes that operate at temperatures below $260{ }^{\circ} \mathrm{C}$. Of that thermal demand, the residential sector makes up the majority of consumption at 55\%, which the remaining portion is due to the industrial (24\%) and commercial (21\%) sectors. Space and water heating alone accounts for $38 \%$ of the thermal energy consumption in the residential and commercial sectors $[9,19]$.

Current geothermal power generation has taken advantage of high temperature hydrothermal reservoirs, and has been limited to specific sites in the western United States. In these areas with hydrothermal reservoir temperatures above $180^{\circ} \mathrm{C}$, flash steam plants make up two-thirds of geothermal installed capacity $[8,20]$. At these high temperatures, liquid is boiled by sudden pressure drop, and the resulting steam sent to a turbine to generate electricity, with remaining hot water further flashed at progressively lower pressures and temperatures, to obtain more steam. 
For potential sites without available water in the reservoir, heat can be still be extracted by the formation of a subsurface fracture system, increasing the permeability of the rock, in which water can be injected. This is referred to as enhanced, or engineered, geothermal systems (EGS) $[8,12,20]$. Water is heated by the surrounded rock and returned to the surface via production wells and run through heat exchangers, similar to naturally occurring hydrothermal systems (Figure 4).

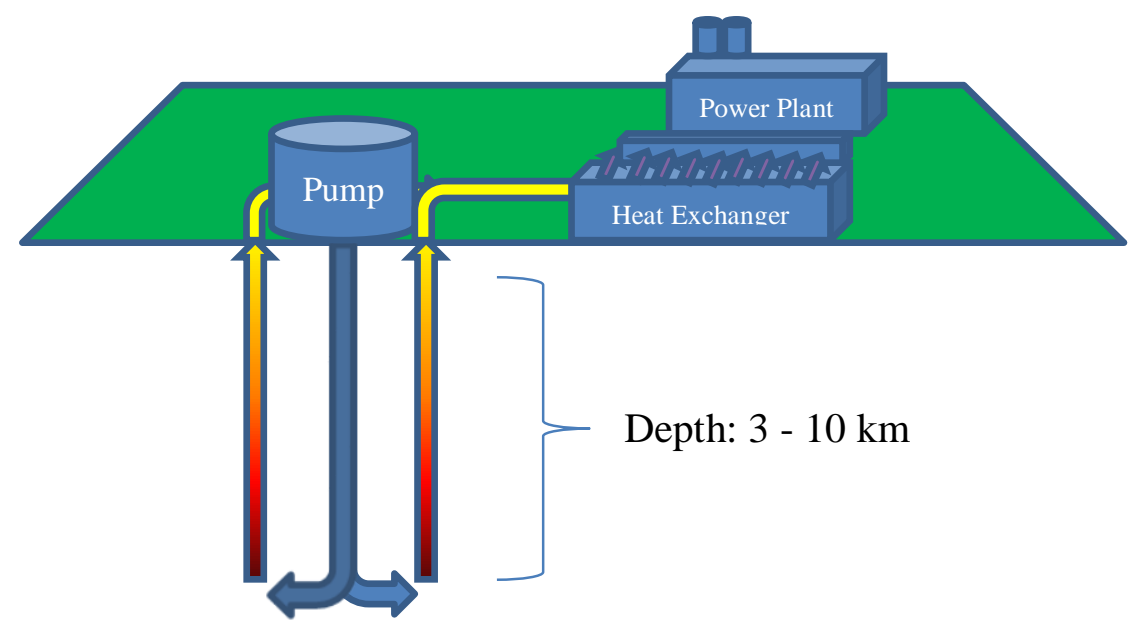

Figure 4. Schematic of a geothermal power plant with one injection well (downward blue arrow) and two production wells (upward gradient arrows).

The recovered geothermal heat can be used for direct-use processes like space and water heating, or can be used to vaporize an organic fluid with a low boiling point to drive a turbine in binary plants. Using an organic Rankine cycle (ORC) or a Kalina cycle, binary plants work well for geothermal sources with temperatures as low as $73^{\circ} \mathrm{C}$. These systems produce $11 \%$ of the installed global generating capacity and represent $44 \%$ of the total number of geothermal plants [21]. Improvements in heat exchangers are allowing for the use of lower temperature fluids, permitting the extension of geothermal development into "traditionally non-geothermal countries" such as Canada, Switzerland and the eastern United States. By implementing 
enhanced geothermal system technology, energy can be harnessed from less favorable geothermal sources, which may have been otherwise disregarded.

\subsection{Rock thermal conductivity}

The continued expansion of low temperature geothermal technology is dependent on knowing where, in terms of geographical location as well as depth, the reservoir of interest is located. Drilling costs alone account for 40 to $60 \%$ of the cost for setting up a geothermal system, with total well costs often 2-5 times greater than oil and gas wells of comparable depth [13]. In low thermal gradient regions, the cost for drilling to the necessary depth to reach required temperatures can make the project unfeasible. Estimation of the temperature-at-depth uses heat flow, which is dependent on factors including geothermal gradient and thermal conductivities $[19,20]$. Thermal conductivity is a function of depth and position, and is calculated as a weighted average based on thicknesses of lithographic layers. Obtaining actual thermal conductivities are difficult, and often require the use of databases to predict the geographic variation.

In the instance of the Appalachian basin, temperature data is largely in the form of oil and gas bottom-hole temperature (BHT) data. BHT is taken to be the maximum-recorded temperature during a logging run, and has been used to model the local temperatures for wells in the petroleum field [21]. The corrected temperature is calculated by assuming a certain temperature gradient, and can be found between the bottomhole circulating temperature (BHCT) and the bottomhole static temperature (BHST) [22]. However, due to the disturbances that occur during the drilling and acquiring process, correction algorithms are necessary to accurately model the well characteristics [23]. Using actual well data is advantageous in that it permits incorporation of a more accurate estimate of sediment thickness at each well location and can utilize these 
estimates of thickness in subsequent calculations, greatly increasing their accuracy. An average thermal gradient ( $\mathrm{dT} / \mathrm{dz})$ can be calculated for the location of each data point using the corrected bottom hole temperature in ${ }^{\circ} \mathrm{C}\left(\mathrm{T}_{\mathrm{BHT}}\right)$, vertical measurement depth in kilometers (z), and average annual surface temperature of the region in ${ }^{\circ} \mathrm{C}\left(\mathrm{T}_{\mathrm{s}}\right)$, as seen in Equation 1.1 [18].

$$
\begin{aligned}
\left(\frac{d T}{d z}\right) & =\frac{T_{B H T}-T_{S}}{z} \\
Q_{S} & =k\left(\frac{d T}{d z}\right)
\end{aligned}
$$

That average thermal gradient is then use with an average thermal conductivity $(\mathrm{k})$ to calculate the surface heat flow at a given location $\left(\mathrm{Q}_{\mathrm{s}}\right)$, as seen in Equation $1.2[18,23]$. The average thermal conductivity for individual well locations can be found by taking the weighted average of the thermal conductivities based on the thicknesses of the underlying geological formations based from AAPG Northern Appalachian COSUNA (Correlation of Stratigraphic Units of North America) cross section [21]. Measured thermal conductivities from known geological stratigraphic layers within the study site may be compared to currently BHT correction algorithms, allowing for further improvement the modeling systems.

\section{Features Influencing Geothermal Expansion}

\subsection{Current geothermal exploration}

In order to determine the optimal location for a potential geothermal system, exploration into the surface and subsurface characteristics must be performed, and is generally referred to as a play fairway analysis. Utilized habitually by oil and gas companies, the purpose of a play 
fairway analysis is to assign risk metrics that examine the favorability of potential sites to enable practical allocation of exploration and development resources. Risk factors for consideration in a geothermal instance are thermal resource quality, natural reservoir quality, induced seismicity, and may include addition factors such as utilization opportunities [21,23]. Cornell and Southern Methodist Universities collaborated on a project as part of the Google.org and NGDS projects that examined 13,800 sites with detailed stratigraphy formations, obtained from the American Association of Petroleum Geologist (AAPG) COSUNA charts, and assigned thermal conductivity values $[21,23,25]$. As expected, several locations in the western United States showed promising high heat flow behaviors conducive for the generation of electricity. Unexpectedly, the work discovered several "warm spots" in the eastern United States Appalachian basin region (Figure 5), with sites in West Virginia reaching temperatures of $150^{\circ} \mathrm{C}$ at a depth of around 4.5 to $5 \mathrm{~km}[23,25]$.

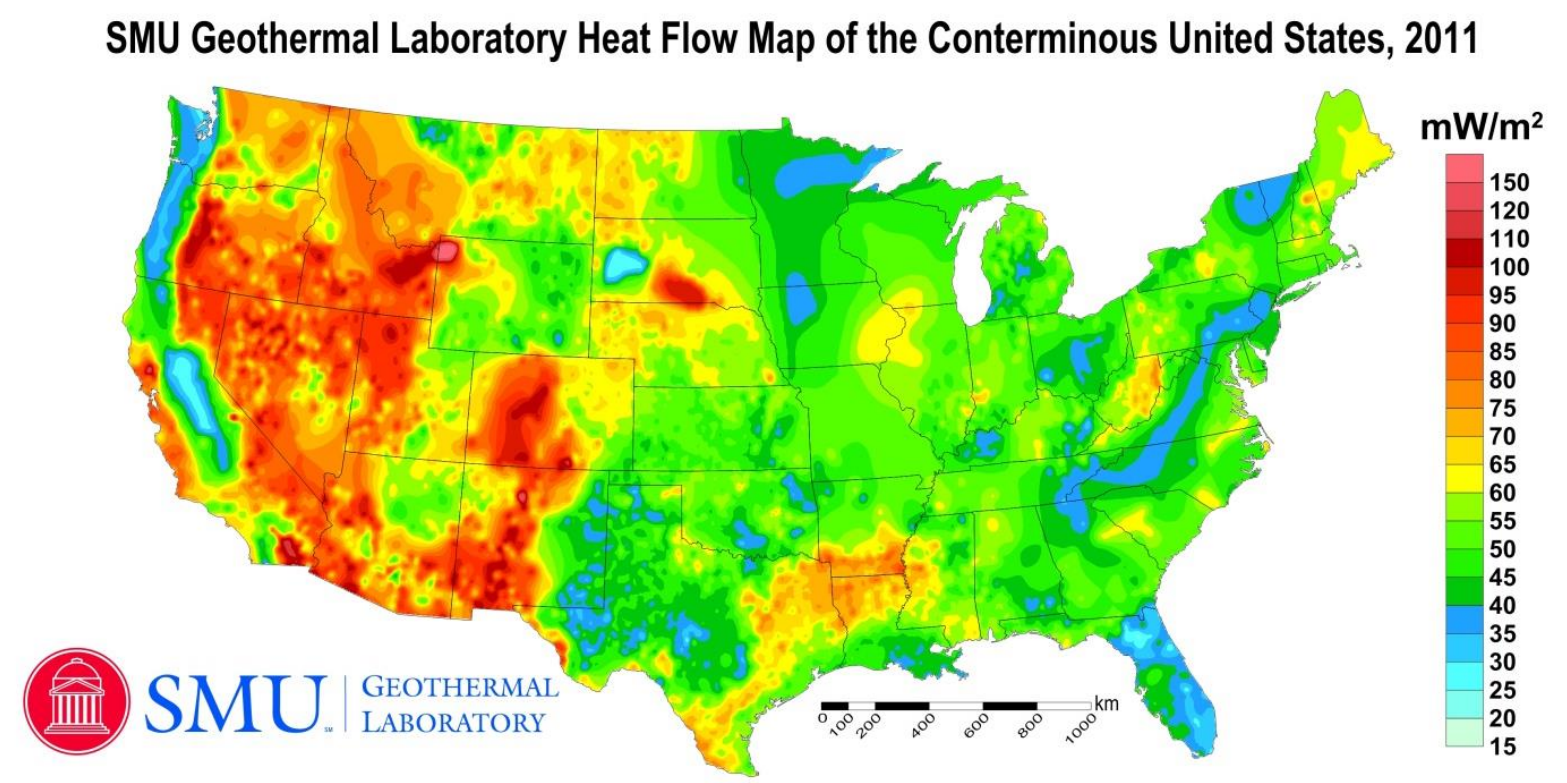

Reference: Blackwell, D.D., Richards, M.C., Frone, Z.S., Batir, J.F., Williams, M.A., Ruzo, A.A., and Dingwall, R.K., 2011, "SMU Geothermal Laboratory Heat Flow Map of the Conterminous United States, 2011". Supported by Google.org. Available at http://www.smu.edu/geothermal.

Figure 5. Heat flow map showing areas geothermal hot spots across of the United States. 
The Appalachian Basin is considered a low temperature geothermal area and is best suited for direct-use applications, such as district heating and cooling, food processing, and some industrial processes [27]. Although direct-use of geothermal energy is limited to the immediate area, it can reduce the electricity requirements for the surrounding region. The presence of such an energy source along the east coast may provide an economic advantage, due to the high demand across highly populated locations, such as New York, Pennsylvania, and West Virginia. Given that the number of low-temperature geothermal resources far exceeds the availability of high-temperature sources in the United States, a low-temperature geothermal play fairway analysis for the Appalachian basin may prove to be the paradigm of future exploitation of this energy source $[28]$.

\subsection{Identification of industrial users}

Direct-use applications are not limited to residential or commercial applications. Many industries are currently using petroleum-based fuels for either electricity production or directly as fuel for heating purposes. Low temperature direct-use of geothermal energy has benefited numerous industries, including aquaculture, green houses, and food processing such as dehydration and dairy processing $[7,8,15,29]$. According to Lund in $2010,47.2 \%$ of thermal energy usage was used for ground-source heat pumps, $25.8 \%$ for bathing and swimming, $14.9 \%$ for space heating (of which $85 \%$ is for district heating), $5.5 \%$ for greenhouses and open ground heating, 2.8\% for industrial process heating, $2.7 \%$ for aquaculture pond and raceway heating, $0.4 \%$ for agricultural drying, and $0.5 \%$ for snow melting [15]. In the Appalachian basin area, the more likely thermal energy users would be for ground source heat pumps, district heating purposes, or industrial use given the climate and limited properties of the accessible geothermal 
energy. District heating differs from space heating in that space heating system tend to require one geothermal well per structure, while district heating involves the distribution of heat, either in the form of hot water or steam, from a central location to individual houses or blocks of buildings via a network of pipes $[8,15]$. This is an important factor to consider when calculating the cost of converting or adding to an existing infrastructure to a geothermal system for a utilization risk assessment for a geothermal study, not just for environmental heating purposes, but replacing energy used for heating processes, such as wood drying and dairy processes, which require a range of temperatures ideal for geothermal application. A well-known example of space heating with low-to-moderate temperature geothermal energy can be found at Oregon Institute of Technology in Klamath Falls, Oregon, where 12 buildings, making up 70,000 sq. m of floor space, are heated via three wells with temperatures approximately $89{ }^{\circ} \mathrm{C}[15]$.

\subsection{Factors Influencing Thermal Conductivity}

According to Midttomme et al, three major factors that may influence thermal conductivity include porosity, minerology, and texture. Texture is influenced by grain size and grain distribution. As the number of fine grain contacts per unit path of heat flow increase, thermal contact resistance increases, resulting in a decreasing the thermal conductivity [22]. Although correlation between thermal conductivity and grain size may be observed, as seen in Figure 6, relationships grain size and other factors that may influence thermal conductivity makes the true effect of grain size alone on thermal conductivity difficult to determine. 


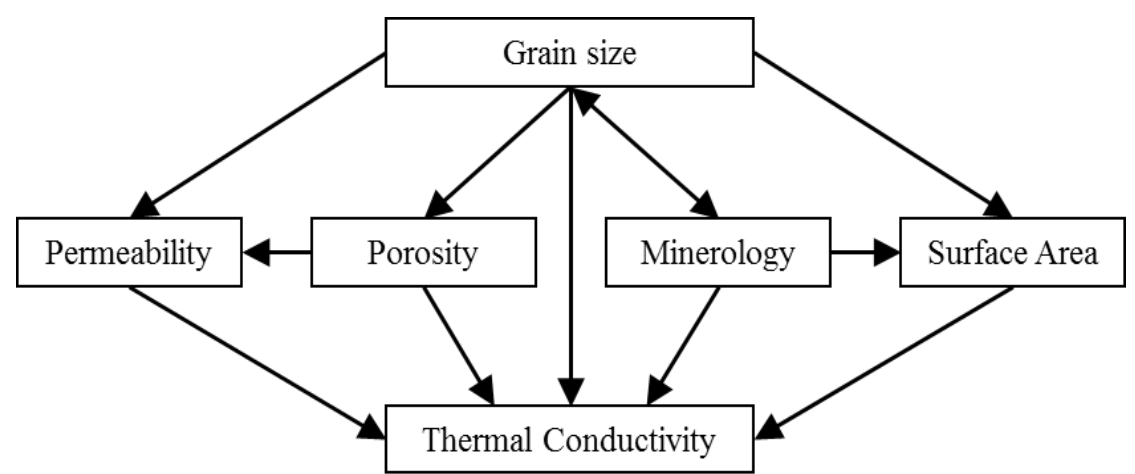

Figure 6. Diagram illustrating the primary and secondary effects of grain size on thermal conductivity. [22]

Thermal conductivity can be measured using two different methods, half space line source or an electronic divided bar method. The line source method works by examining the transient heat flow experienced by a sample being constantly heated and under pressure. The increase in temperature is measured from within the sample, and by examining the resulting heating curve, the thermal conductivity of the sample is determined. [22,23] For the divided bar method, a sample is placed between a heat source and a heat sink, and a steady state temperature gradient across a rock sample is reached. [22-24] Advantages to the divided bar system include small sample size requirements, and the ability to obtain unambiguous values of thermal conductivities in a given direction, with the main time consuming step the sample preparation. Samples for the divided bar method can take the form of a rock core sample between the size of 30 to $65 \mathrm{~mm}$ in diameter and 10 to $30 \mathrm{~mm}$ in thickness, or in the form of rock cuttings. Since continuous coring tends to be a rare event, rock cuttings are the more usual sample form thermal conductivity analysis. [22,24] To determine whether the form of the sample influenced the resulting thermal conductivity, Pribnow et al took readings from rock cores, then crushed them to generate rock cuttings for the analysis. 
Pribnow et al considered two different approaches to this experiment. One method of addressing the rock fragment-water mixture was by calculating the thermal conductivity using a geometric mean, as seen in equation 2.1 .

$$
\lambda_{G}=\lambda_{F}^{1-\phi} \lambda_{W}^{\phi}
$$

In this model, $\boldsymbol{\lambda}_{\mathrm{G}}$ is the measured value from the mixture, $\boldsymbol{\lambda}_{\mathrm{F}}$ is the thermal conductivity of the rock fragments, $\lambda_{\mathrm{W}}$ is the thermal conductivity of water $(0.6 \mathrm{~W} / \mathrm{m}-\mathrm{K})$, and $\boldsymbol{\phi}$ is the volume fraction of water in the mixture. [23]

In contrast, the layered model examines the heat flow behavior by differentiating between parallel and perpendicular components in regards to thermal conductivity as well as setting the thickness proportional to the volume fractions in the mixture, with the parallel component resulting in the upper limit $\left(\boldsymbol{\lambda}_{\mathrm{U}}\right)$ and the perpendicular component the lower limit $\left(\boldsymbol{\lambda}_{\mathrm{L}}\right)$ of the thermal conductivity. [23] Since neither of these two points provide a realistic description of the observed thermal conductivity, a geometric mean of both values assumes a mixture of randomly distributed, equal quantity of parallel and series arrangements for any value of $\boldsymbol{\phi}$ (Equation 2.2).

$$
\lambda_{U * L}=\lambda_{U}^{0.5} \lambda_{L}^{0.5}
$$



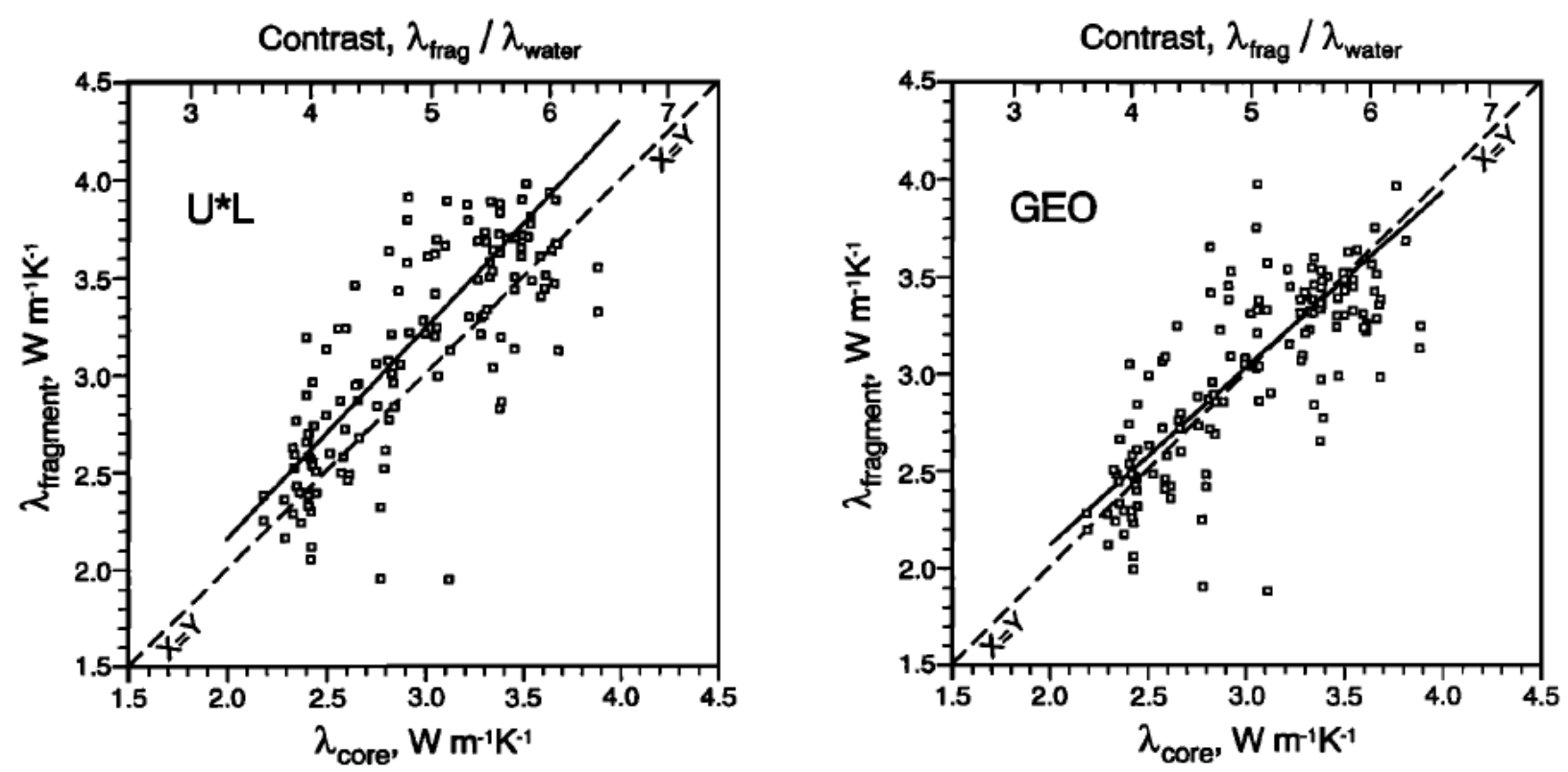

Figure 7. Comparison of thermal conductivity measured on intact cores with fragment determinations after the cores were crushed. Dashed line is one to one correspondence; solid line is linear regression; (left) layered model (U*L); (right) geometric mean model (GEO). [23]

In Figure 7A, the regression line for layered model shows an overestimation, with the absolute difference increasing slightly with increases in contrast $\boldsymbol{\lambda}_{\mathrm{F}} / \boldsymbol{\lambda}_{\mathrm{W}}$. The authors propose this being a result of potential overdetermination of the water fraction. In Figure 7B, the geometric mean appears to provide a fair representation over the range of contrast $\boldsymbol{\lambda}_{\mathrm{F}} / \boldsymbol{\lambda}_{\mathrm{W}}$, and the average thermal conductivity values between cores and fragments considered to be equal (cores $3.09+/-0.56$ $\mathrm{W} / \mathrm{m}-\mathrm{K}$ and fragments $3.06+/-0.47 \mathrm{~W} / \mathrm{m}-\mathrm{K})$. [23] 


\section{Objectives}

The drive toward energy sources with low to zero carbon dioxide emissions has promoted innovative progression in the renewable energy field. This project aims to create a knowledge base that may be applied in both the initial stages of subsurface modeling of low temperature geothermal resource heat flow assessment, as well as later utilization stages for determining the optimized sites for direct use applications.

For the utilization component of the play fairway analysis, levelized cost of heat (LCOH) is used as a metric that provides a comparison of the combination of capital costs, operation and maintenance costs, and performance and fuel costs $[18,19,33]$. The model used for the Appalachian play fairway analysis was a system created by a team at Cornell University, in which the $\mathrm{LCOH}$ for a given Census "place" was determined by incorporating given properties for the model such as capital costs, lifespan for the system, and discount rates in GEOPHIRES with an Excel spreadsheet with data collected from the United States Census for residential, commercial, and infrastructure within a Census "place" $[19,38]$. One aspect of the model that was not developed in the original model was the impact of manufacturing sites which may benefit from the development of a geothermal system. Industries considered include dairy processing, paper mills, wood/timber drying, universities and colleges, and military bases. This diverse collection of manufacturing and professional sites allows for an evaluation of different components that may be seen during future development. Dairy processing, paper mills, and wood drying contains two main factors: process heating and floor space heating. [36,37] The current existence or need for a district heating system infrastructure at military bases, universities, and colleges could improve or discourage the implementation of a geothermal system in local area. [28] In addition, this work supplemented a well-specific thermal 
conductivity library by determine the thermal conductivities of rock cuttings collected from Well \#244 in Marion County, WV. Stratigraphic information can be found via the United States Geological Survey geologic cross section D-D', which examined the Appalachian basin from the Findlay arch in northwestern Ohio to the Valley and Ridge province in eastern West Virginia based on 13 deep drill holes. [29] Comparison of thermal conductivities collected from actual rock cuttings and associating them to estimates used with bottom hole temperature modeling systems for heat flow mapping analyses would provide an interesting discussion for understanding the geological behavior in the Appalachian basin as well as its potential geothermal exploration.

\section{Experimental Design}

\subsection{Utilization Risk for Play Fairway Analysis}

\subsubsection{Description of Programs}

This research utilized the MathWorks program MATLAB as the interface between completed the Microsoft Excel file created in section 4.1.2 and the main source code program GEOPHIRES (Geothermal Energy for Production of Electricity and Heat Economically Simulated) designed by Koenraad Beckers [39]. Factors considered in the GEOPHIRES program included surface piping, heat exchange equipment (residential and/or commercial), operations, upfront capital cost, and maintenance costs over the lifetime of a 30 -year project to determine the Levelized Cost of Heat (LCOH) for each Census 'place'. The GEOPHIRES program can be customized to include subsurface conditions, such as fluid temperature, flow rate, and drilling costs, and temperature gradients for Census places. This allowed drilling cost to be a part of the $\mathrm{LCOH}$ calculation. The GEOPHIRES program used a fixed annual charge 
rate (FACR), allowing the user to specify several factors, including discount rates, to the capital investment (I), adding the annual operation and maintenance cost (O\&M), and dividing by the annual production $(\mathrm{Q})$ to determine the estimated cost of heat $(\mathrm{COH})$ in $\$ / \mathrm{MMBTU}$ (Equation 4.1) [19].

$$
C O H=\frac{I * F A C R+O \& M}{Q}
$$

As reported by Shaalan in 2001, "the average or 'levelized' annual carrying charges including interest or return on the installed capital, depreciation or return of the capital, tax expense, and insurance expense associated with the installation of a particular generating unit" [40]. Unfortunately, one concern with the fixed annual charge rate methodology is that changes in the plant lifetime are tied in with the assumed FACR value, causing plant and equipment lifetime sensitivity analyses to be difficult to determine. As a result, a second levelized cost of heat $(\mathrm{LCOH})$ based on discounted cash-flow methodology was used outside of the GEOPHIRES model (Equation 4.2) [19].

$$
L C O H=\frac{\sum_{t=1}^{\text {Lifetime }}\left(I_{t}+O \& M_{t}\right) /(1+d)^{t}}{\sum_{t=1}^{\text {Lifetime }} Q /(1+d)^{t}}
$$

In this new equation, $\mathrm{I}_{\mathrm{t}}$ is the capital investment in year $t, \mathrm{O} \& \mathrm{M}_{\mathrm{t}}$ is the total operation and maintenance cost in year $t, \mathrm{Q}$ is the energy sold in year $t$, and $d$ is the discount rate. Discount rates for public utilities rather than investor-owned utilities were used in order to provide a method of comparison between the two cost estimation. For the Play Fairway Analysis utilization risk, $1 \%$ was added to the publicly owned value resulting in a FACR value of $6 \%$. According to Rushing et al. (2011) the U.S. Department of Commerce calculated an effective discount rate of 3\% in 2011 for Federal and Public energy projects. Therefore 1\% was also 
added to this value, resulting in a discount rate of $4 \%$ applied to SLCOH $[19,41]$.

\subsubsection{Overview of Residential Levelized Cost of Heat Method}

The West Virginia area of the Appalachian basin was added to the preexisting New York and Pennsylvania statistics of the play fairway analysis by following the method developed by Reber et al at Cornell University. This technique utilized data collected by the United States Census Bureau, via the FactFinder website, and contains information at the 'state', 'county', 'county subdivision', 'economic place', as well as 'place' level. A 'place' is defined as 'settled concentrations of population that are identifiable by name but are not legally incorporated" which may include individual cities, towns, villages, boroughs, and other Census-Designated Places (CDP's) [42-50]. To maintain consistency with the New York and Pennsylvania values, the 2010 Census data collection was selected for the West Virginia data, a total of 3,355 'places' within the borders of all three states were initially considered. Figure 8 shows the census 'places', represented as small, jagged polygons within the Appalachian basin border, shown with the double line. 


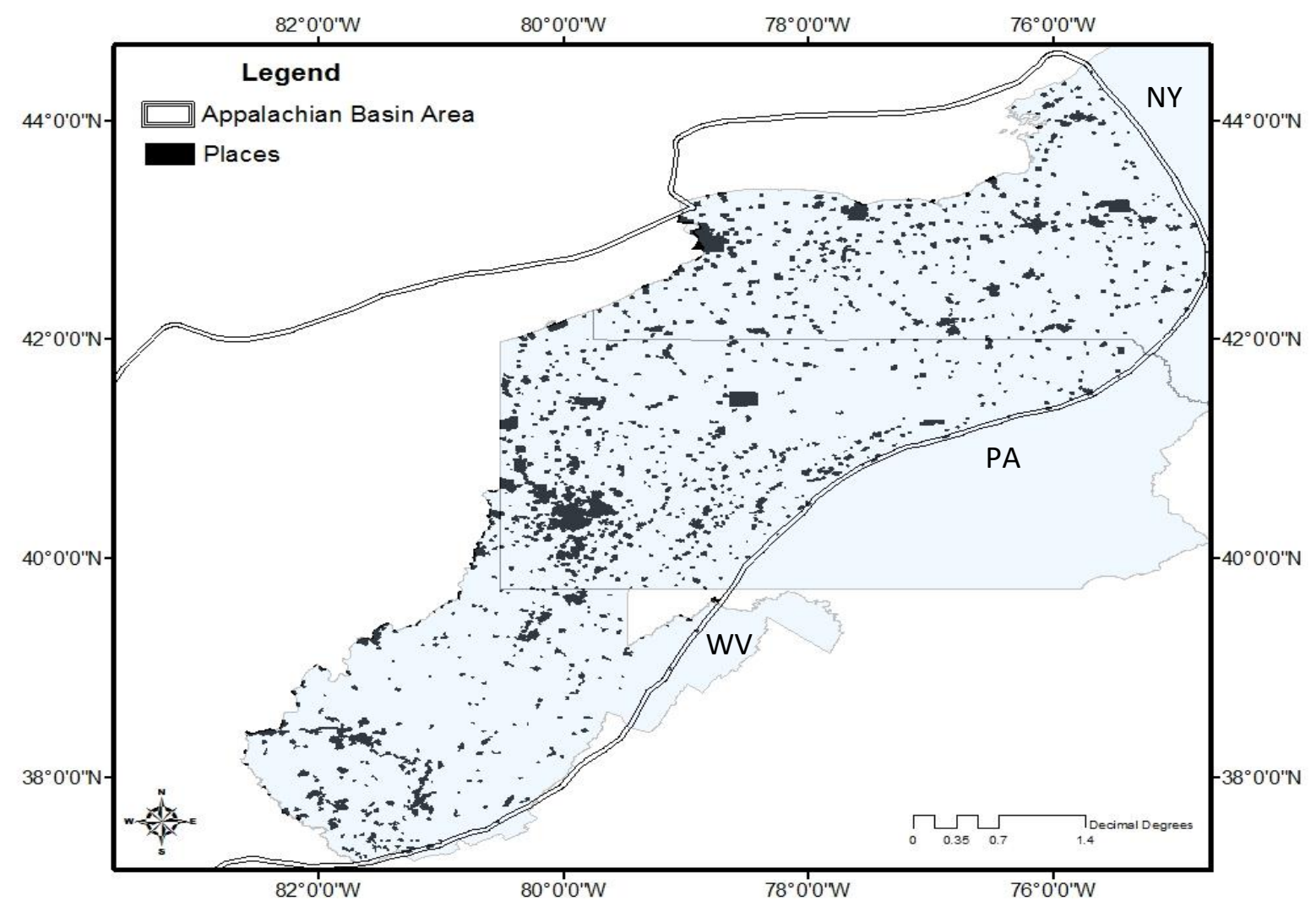

Figure 8. Overlay of Appalachian Basin over the three states of interest (WV, PA, NY).

The ESRI program ArcGIS was used to link 'place' data to corresponding 'county subdivision' and 'county' and 'economic place' data. To complete this task, shapefiles of the places and respective Census data were put into ArcGIS, and by using a spatial join, the program joined the attributes tables of the two files, matching the information for the 'places' to the corresponding 'county' data. Finally, all sites were checked and any 'places' without a successful join had data manually added. This process was repeated to relate places with 'country subdivision' and 'economic place'. This allowed for a comparison of 'place' population to country population for a more accurate representation of the population density.

Due to the quantity of the information collected, there were three main files: commercial data, housing data, and road data. For the commercial data, EIA's Commercial Buildings Energy 
Consumption Survey (CBECS) reported in 2006 was used to estimate the total floor space for each industry type for each place. From these data the average number of establishments per building by commerce type was determined [42-50].

For the commercial file, 2007 Economic Data was collected for twelve facets: Accommodation, Food, \& Other Services, Administrative and Support and Waste Management and Remediation Services, Arts, Entertainment, and Recreation, Educational Services, Health Care and Social Assistance, Information Geographic Area Series, Manufacturing, Other Services, Professional Scientific and Technical Services, Real Estate and Rental and Leasing, Retail Trade, and Wholesale Trade. From these files, the number of establishments and number of employees were collected for each "economic place". Unfortunately, the term "economic place" did not equate to that of the census definition of "place." The "economic place" can be related to the census classification of "county subdivision." Following with methodology of Reber et al, in the instance where a single "county subdivision" (i.e. "economic place") contained multiple "places", often seen in highly populated areas, the data on commercial establishments for that county subdivision was divided amongst the "places" within that county subdivision based on the relative population of each "place." In addition, due to the potentially identifiable nature of the reported economic data, some employment sizes were represented by a letter which stood for a range of values. ${ }^{1}$ This allowed for the Matlab/GEOPHIRES model to have a numerical value to perform the calculations.

Housing data for each 'place' was found using the Census Factfinder under “American Community Survey" using the 2010 5-year estimates and code B25024, representing the number

\footnotetext{
${ }^{1}$ For example, "A" meant an establishment had less than 20 employees, "B" meant an establishment may have between 20 to 99 employees, "C" means 100 to 249 employees, etc.). For these sites, the average of the range rounded up to the next integer was used for the model (ex. "A" would have 10 employees, "B" would have 60 employees, "C" would have 175 employees, etc.).
} 
and type of housing units per residential building category (i.e. detached single-family, attached single-family, 2 unit buildings, 3-4 unit buildings, 5-9 unit buildings, 10-19 unit buildings, 20-49 unit buildings, and 50+ unit buildings). The Energy Information Agency (EIA) performs a Residential Energy Consumption Survey (2009) that we used to determine average square footage of each designated unit and related heating load on a Census region basis.

Following the method of Reber et al, the total length of roads within each "place" was used as a method to estimate the required piping length required to service a given location. It was determined that $75 \%$ road coverage would provide adequate piping density required to reach all buildings for geothermal district heating system.

\subsubsection{Final Considerations and Program Outputs}

Since all temperature, reservoir and other map were limited to the basin outline, any place not within the project area of the basin with an additional boundary of $10 \mathrm{~km}$ was not included in the analysis, resulting in a reduction of possibly places to 1,697 . These sites were then put in a Microsoft Excel input file format and run through GEOPHIRES.

The results output were spreadsheets that were sorted based on the population size and the resulting SLCOH in the units dollars per one million BTU (British Thermal Unit). (\$/MMBTU). Finally, a minimum population density threshold of 4,000 residents per place was applied across all three states; therefore any place with a population of less than 4,000, the SLCOH was assigned a value of $\$ 100$. This allowed for exclusion of 'places' with populations less than 4,000 without the loss of potential sites for later considerations, such as for the inclusion of potential industrial sites. The reasoning for the threshold was that a high cost per resident would discourage potential utilizers of the direct use application. This gave a final number of 'places' 
for the SLOCH analysis to be 248. Of these sites, the 'places' with the least expensive SLCOH were considered "best case" sites.

\subsection{Industrial site analysis}

Initial SLCOH findings initiated discussions of the inclusion of industries in the calculations, particularly with Census 'places' with populations less than 4,000. Industries considered across West Virginia, Pennsylvania and New York fell into the categories of paper mills, wood drying kilns, dairy processing which includes yogurt and milk pasteurization products, college and university campuses, and select military locations. Table 1 illustrates examples of temperature ranges.

Table 1. Temperature ranges for industries considered for this analysis.

\begin{tabular}{|l|l|}
\hline Industry & Temperature Range \\
\hline Dairy & $\begin{array}{l}\text { Butter/yogurt production } 80-90{ }^{\circ} \mathrm{C} \\
\text { Traditional pasteurization } 72-75{ }^{\circ} \mathrm{C}\end{array}$ \\
\hline Wood Drying & $43-82^{\circ} \mathrm{C}$ \\
\hline Paper/pulp mills & $66-150^{\circ} \mathrm{C}$ \\
\hline University/College campuses & $148.9^{\circ} \mathrm{C}$ \\
\hline Military stations & $148.9^{\circ} \mathrm{C}$ \\
\hline
\end{tabular}

Each site was located using GoogleMaps except for the locations of the dairy processing sites which were found using the Dairy Foods website [25]. Each of these potential users has a component of their process(es) which could benefit from incorporating a geothermal element into their system, either by preheating or reducing electrically heated steps. Figure 9 shows the 
locations of potential industries that fell within a census place which might benefit from the inclusion of an industrial body in the levelized cost of heat calculations.

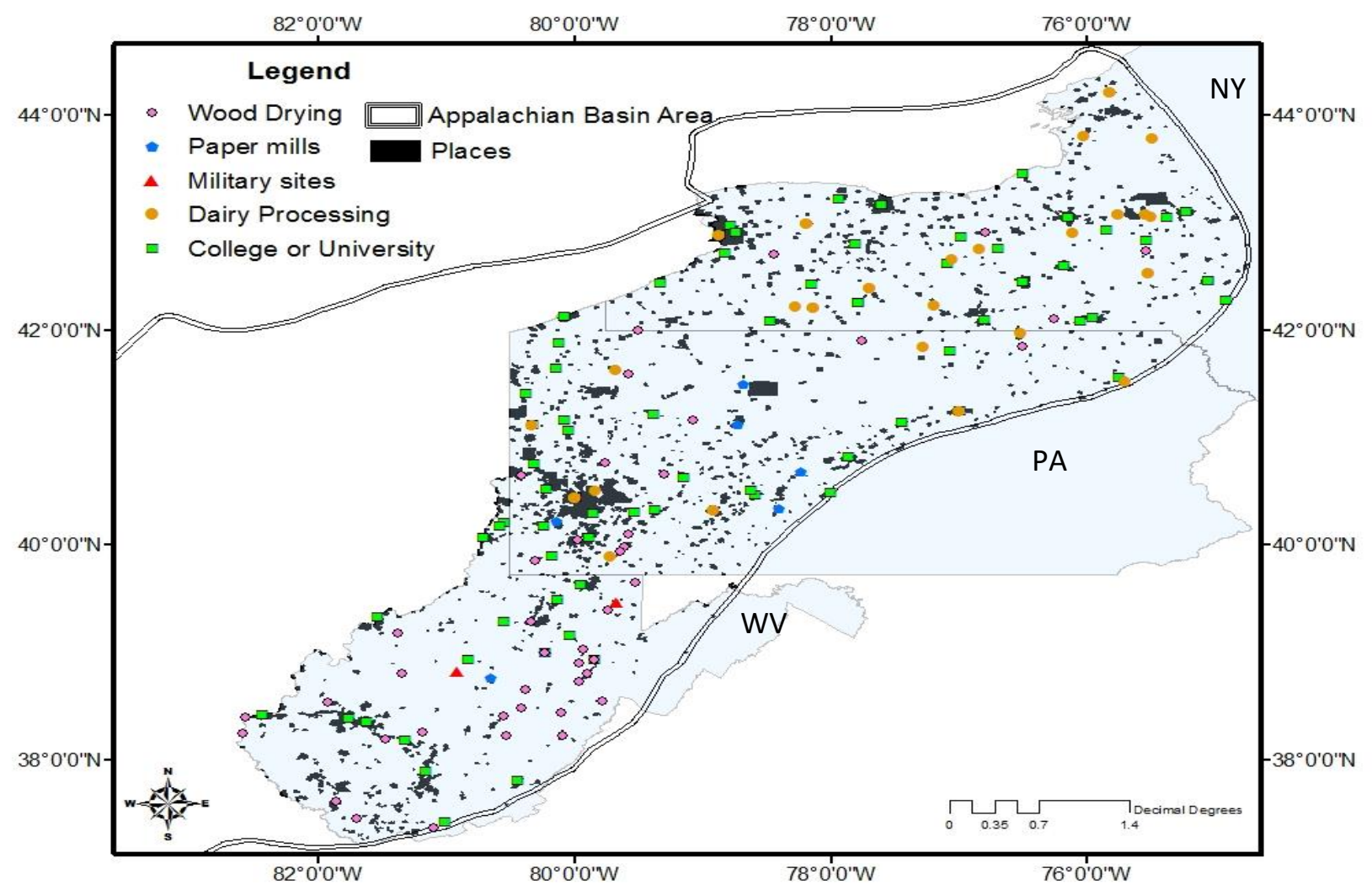

Figure 9. Industries located in Census 'places' within the Appalachian Basin tristate area.

The method used for the manufacturing/industrial sector calculations paralleled the commercial and residential sectors by Reber et al in the initial SLCOH calculations, by using 2006 data set of US Census Manufacturing Energy Consumption Survey (MECS). [38]

Manufacturing energy consumption are broken into three large categories: direct use process. direct use non-process, and indirect uses. As the name implies, direct use process is energy put toward changing the properties of a product, such as process heating, process cooling and refrigeration, machine drive electro-chemical processes, etc. In contrast, direct use non-process is energy put toward facility functions, such as HVAC, lighting, onsite transportation, and possible 
conventional electricity generation. Indirect uses include conventional boiler use or cogeneration processes $(\mathrm{CHP})$. Due the low temperature availability of the geothermal system, process heating and HVAC energy usage was considered in the calculations for the dairy processing, wood drying and paper mills.

Similar to the base case model with the residential and commercial aspects, once industrial locations were selected, each of the 176 industries was matched to a US Census 'place' which was found within the Appalachian basin border using ArcGIS. In the instances when a match was not made, sites were manually assigned. Due to the nature of the industries, some 'places' had more than one industry assigned to them, resulting in a total number of 121 'places'.

For the analysis, MECS data was used to determine the average enclosed square footage for each industry, specifically "dairy products", "sawmills", and "paper mills, except newsprint". Total energy expended for direct use non-process energy, specifically HVAC, was then used to find the floor space energy intensities (in MBTU/ft²/year). In addition to space heating, industries also have direct use, total process energy usage. This includes process heating, process cooling and refrigeration, and was included in the manufacturing process demand calculation (MBTU/year).

At this point in time, very few United State colleges utilize geothermal energy as a form of space heating and cool. One example is the above mentioned Oregon Institute of Technology in Klamath Falls, Oregon, where 12 buildings, making up 70,000 $\mathrm{m}^{2}$ of floor space, are heated via three wells with temperatures approximately $89^{\circ} \mathrm{C}$ [15]. Xiaoning He performed a case study for West Virginia University, in which he examined the efficacy of converting the existing Evansdale campus to take advantage of an engineered geothermal system. [28] The Evansdale 
campus uses a steam/water heat exchanger system, in which steam is carried to each building and passes its heat to circulating water which passes through the building's radiation system. Xiaoning He proposed that these steam pipelines could easily carry geothermal water, minimizing infrastructure modifications. The Evansdale campus maintains two 300 ton dual stage steam absorption chillers and two 600 ton dual stage steam absorption chillers for cooling a total space of 75,000 $\mathrm{m}^{2}$. According to Aspen Plus economic model, the equipment purchase cost for the heating and cooling system would be $\$ 0.2$ and $\$ 0.69$ million, respectively. In addition to equipment costs, the Association for the Advancement of Cost Engineering International (AACE) recommended an additional \$2.34 million for installation, handling, and other indirect cost such as general facilities and overhead, resulting in a total surface capital was estimated at $\$ 3.23$ million. Since both the Oregon model [16] and WVU model take into account similar square floor space, this became the basis for the model that, if other locations such as other universities or military bases, had a similar heat/cooling system in place, the resulting cost credit may decrease the overall levelized cost of heat for a given Census 'place', improving the appeal for potential EGS development in that area. 


\subsection{Thermal conductivity analysis of well data}

The thermal conductivities of the rock samples collected from the West Virginia wells were analyzed using a Portable Electronic Divided Bar supplied by Hot Dry Rocks, Geothermal Energy Consultants. PEDB is designed to measure thermal conductivities of rock samples in both the field and laboratory setting. A temperature gradient was generated by two parallel temperature plates, in which two sets of thermocouples are located, as illustrated in Figure 10.

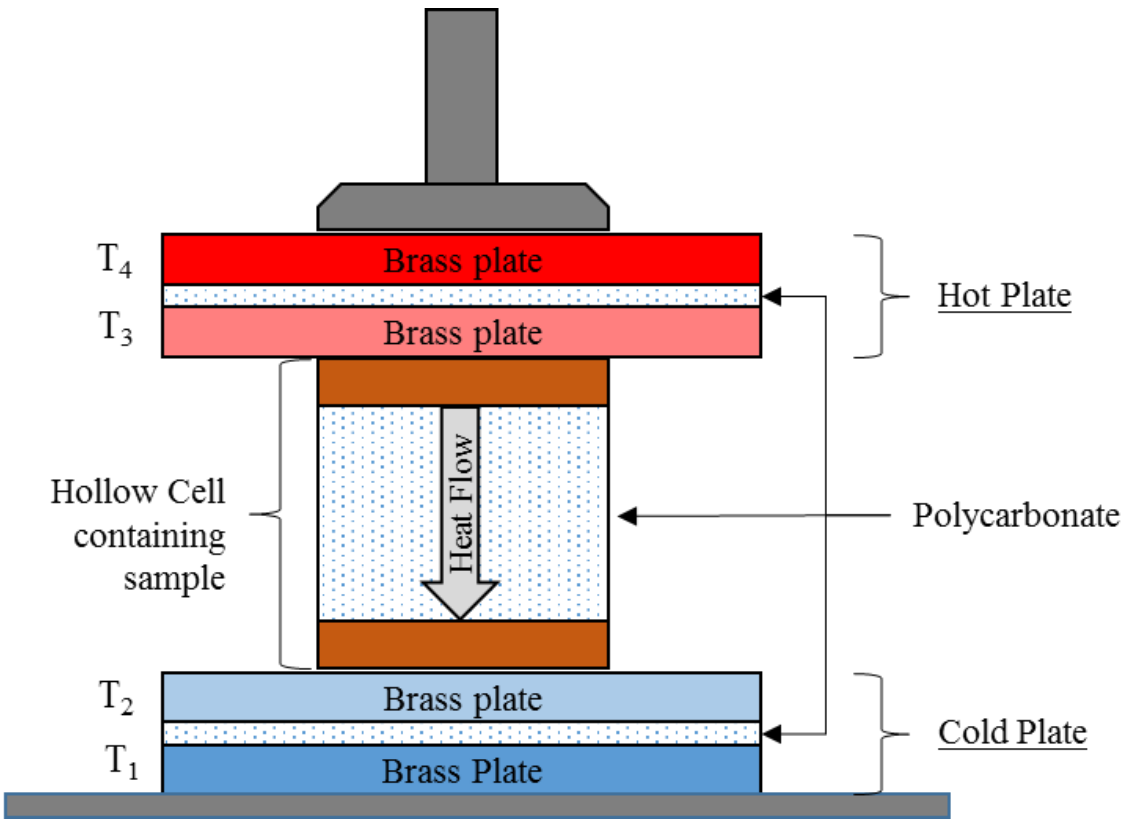

Figure 10. Illustration of the PEDB and hollow cell containing sample setup. Each hot and cold plate system is made up of two brass plates with a polycarbonate layer between with a heat source located above the hot plate and a cooling mechanism below the cold plate, generating the thermal gradient through the sample containing hollow cell. [24]

The PEDB uses Fourier's Law (Equation 4.3) to determine the thermal conductivity, $\lambda$.

$$
\begin{gathered}
\lambda=\frac{d}{R} \\
R=(A(\Delta T-c)) /(\text { a }(\text { diameter }+b)) \\
\Delta T=\frac{T_{3}-T_{2}}{\left(T_{4}-T_{3}\right)+\left(T_{2}-T_{1}\right)}
\end{gathered}
$$


Where $\mathrm{a}, \mathrm{b}$, and $\mathrm{c}$ are calibration constants, $\mathrm{d}$ is the thickness of sample in millimeters and $\mathrm{A}$ is the surface area of sample in square millimeters. The $\Delta \mathrm{T}$ is found by Equation 3 , where $\mathrm{T}_{1}, \mathrm{~T}_{2}$, $\mathrm{T}_{3}$, and $\mathrm{T}_{4}$ are temperatures recorded by the thermocouples in the PEDB plates. [24]

To prepare a sample for analysis, a rock sample was dehydrated for 12 hours, placed into a preweighed hollow cell device within $3 \mathrm{~mm}$ of the rim of the cell, and dry weight of the hollow cell and sample recorded. The hollow cell with sample were submerged in deionized water under vacuum for 12 hours to ensure complete saturation of the rock sample. Once saturated, the hollow cell with the sample was removed from the water bath, patted dry and saturated weight recorded. After checking to ensure lids were secured, the top and bottom of the cell was coated with a layer of petroleum gel to allow better contact with the thermocouple plate during measurement. Exposed sides of the cylinders were covered with foam padding to ensure vertical transmission of heat through the sample, and the change in temperature $(\Delta \mathrm{T})$ is recorded by PicoLog data logging software. The system was allowed to reach steady state, and the resulting steady state $\Delta \mathrm{T}$ (in ${ }^{\circ} \mathrm{C}$ ) used in a spreadsheet with the specific hollow cell dimensions and empty hollow cell thermal conductivity to determine the thermal conductivity of the rock cutting sample.

To test the effect of grain size on thermal conductivity, samples of limestone rock were separated using different gradients of sieves. Each gradient sample was photographed with a micrometer to provide a standard unit of length. Each photograph was analyzed using ImageJ (Image Processing and Analysis in Java) a freeware the National Institute of Health over 50-75 rock pieces were measures to determine an average grain sizes. [33] Four samples with grain sizes most similar to those seen in well samples were selected (seen in Table 2), and their thermal conductivities measured using the PEDB method in triplicate. 
Table 2. Comparison of grain size of limestone samples to grain sizes found with Marion County \#244 well samples

\begin{tabular}{|c|c|c|c|}
\hline Sample & $\begin{array}{l}\text { Average limestone } \\
\text { Grain (mm) }\end{array}$ & $\begin{array}{l}\text { Average Well } \\
\text { Grain (mm) }\end{array}$ & $\begin{array}{l}\text { Corresponding } \\
\text { Well Depth (ft) }\end{array}$ \\
\hline Large & 9.29 & NA & NA \\
\hline $\begin{array}{c}\text { Medium } \\
\text { Large }\end{array}$ & 3.02 & 2.92 & $11900-12000$ \\
\hline $\begin{array}{c}\text { Medium } \\
\text { Small }\end{array}$ & 1.85 & 1.39 & $10100-10200$ \\
\hline Powder & 0.294 & 0.356 & $8900-9000$ \\
\hline
\end{tabular}

\section{Results and Discussion}

\subsection{Impact of Industrial Demand and Existing Infrastructure Credits on LCOH}

Of the 121 census 'places' with potential manufacturing and educational users, 60 'places' had just dairy, wood drying, or paper mill form of industry, and the remaining 'places' contained university or colleges and possibly an industry. For each industry, both space heating intensities as well as process heating, cooling and refrigeration were combined into the GEOPHIRES analysis tool, and the resulting $\mathrm{LCOH}$ values compared to based case values for each of the census places. For the university and military aspects, space and water heating were the prominent sources of energy usage. However, some universities, such as West Virginia University, may own equipment that may easily be converted to accommodate geothermal energy. Tables 3 through 5 list the sites with the lowest base case SLCOH values for West Virginia, Pennsylvania, and New York based on the 'place' analysis methodology are listed in the experimental design section. For most census places listed in the tables, the resulting increase in demand results in a decrease in $\mathrm{LCOH}$, as well as the addition of the infrastructure credit for universities that contain existing systems which may easily be converted to geothermal use. LCOH of Census 'places' within this project included thermal gradient information for that area, 
therefore below ground costs for drilling and completion of wells are included in the reported LCOH values.

Table 3. Top ten West Virginia census places with lowest base case LCOH with populations greater than 4000, compared to impact on $\mathrm{LCOH}$ of adding manufacturing demand.

\begin{tabular}{|c|c|c|c|c|}
\hline City & County & Population & $\begin{array}{c}\text { LCOH (base) } \\
\text { \$/MMBTU }\end{array}$ & $\begin{array}{c}\text { LCOH with } \\
\text { Manufacturing } \\
\text { \$/MMBTU }\end{array}$ \\
\hline Elkins & Randolph County & 7094 & 10.771 & 8.825 \\
\hline Princeton & Mercer County & 6432 & 10.928 & 10.928 \\
\hline Wheeling & Ohio county & 28486 & 10.969 & 8.946 \\
\hline Morgantown & Monongalia County & 29660 & 10.989 & 8.954 \\
\hline Clarksburg & Harrison County & 16578 & 11.005 & 11.005 \\
\hline Buckhannon & Upshur County & 5639 & 11.036 & 9.004 \\
\hline Fairmont & Marion County & 18704 & 11.036 & 9.981 \\
\hline Vienna & Wood County & 10749 & 11.289 & 9.268 \\
\hline Charleston & Kanawha County & 51400 & 11.444 & 9.385 \\
\hline Huntington & Cabell County & 49138 & 11.589 & \\
\hline
\end{tabular}

Morgantown, WV is of interest given that West Virginia University has a district heating system that could be converted to handle a geothermal system, as described by Xiaoning et al. Another site of interest includes Kingwood (population 2,939 residents), site of Camp Dawson, ranked in the lower half of WV results (215 of West Virginia's 388 sites) but due to the presence of a district heating system, in addition to local interest of converting it to geothermal system, analysis showed that it would have an LCOH of $\$ 10.69 / \mathrm{MMBTU}$ after addition of the infrastructure credit. 
The top ten locations in New York and Pennsylvania (Table 4 and 5, respectively) were also ranked by lowest base case $\mathrm{LCOH}$ value with census places with populations greater than 4,000 .

Table 4. Top ten New York census places with lowest base case LCOH with populations greater than 4000, compared to impact on LCOH of adding manufacturing demand.

\begin{tabular}{|c|c|c|c|c|}
\hline City & County & Population & $\begin{array}{c}\text { LCOH (base) } \\
\text { \$/MMBTU }\end{array}$ & $\begin{array}{c}\text { LCOH with } \\
\text { Manufacturing } \\
\text { \$/MMBTU }\end{array}$ \\
\hline Adams village & Jefferson County & 13,261 & 7.845 & 7.845 \\
\hline Batavia & Genesee County & 4,174 & 9.680 & 9.680 \\
\hline Buffalo & Erie County & 29,200 & 9.835 & 9.835 \\
\hline Campbell & Steuben County & 8,031 & 10.065 & 10.065 \\
\hline Cazenovia & Madison County & 5,159 & 10.081 & 10.081 \\
\hline Cheektowaga & Erie County & 18,142 & 10.088 & 10.088 \\
\hline Oswego & Oswego County & 18,142 & 10.088 & 10.088 \\
\hline Clinton village & Oneida County & 15,465 & 10.128 & 10.128 \\
\hline Cuba village & Allegany County & 8,366 & 10.234 & 10.234 \\
\hline Delhi village & Delaware County & 75,178 & 10.266 & 10.266 \\
\hline
\end{tabular}

Table 5. Top ten Pennsylvania census places with lowest base case LCOH with populations greater than 4000, compared to impact on LCOH of adding manufacturing demand.

\begin{tabular}{|c|c|c|c|c|}
\hline City & County & Population & $\begin{array}{c}\text { LCOH (base) } \\
\text { \$/MMBTU }\end{array}$ & $\begin{array}{c}\text { LCOH with } \\
\text { Manufacturing } \\
\text { \$/MMBTU }\end{array}$ \\
\hline Clarion borough & Clarion County & 5,276 & 8.030 & 6.876 \\
\hline Warren city & Venango County & 9,710 & 8.284 & 8.284 \\
\hline Washington city & Washington County & 9,710 & 9.017 & 7.661 \\
\hline Oil City & Venango County & 10,557 & 9.461 & 9.461 \\
\hline California & Washington County & 6,795 & 9.986 & 8.474 \\
\hline Titusville & Crawford County & 5,601 & 10.221 & 10.218 \\
\hline Meadville & Crawford County & 13,388 & 10.278 & 8.445 \\
\hline Edinboro & Erie County & 6,438 & 10.283 & 8.438 \\
\hline Greenville & Mercer County & 5,919 & 10.497 & 8.579 \\
\hline Grove City & Mercer County & 8,322 & 10.566 & 8.673 \\
\hline
\end{tabular}


Unlike West Virginia, both New York and Pennsylvania have countries that occur several times in the top ten base case census places, illustrating that building a geothermal system in those countries would potentially benefit the surrounding area on a county level, rather than just city level.

\subsection{Thermal Conductivity Findings}

To ensure that the size of the grain seen in the rock cuttings from Marion County well \#244 did not impact the measured thermal conductivities, thermal conductivities were measured on four different sizes which related to the rock cuttings from the well. Samples were run in triplicate to ensure valid results. Table 6 shows the results from this experiment.

Table 6. Analysis of the impact of grain size on thermal conductivity.

\begin{tabular}{|l|l|l|l|l|}
\hline $\begin{array}{l}\text { Rock sample } \\
\text { (size) }\end{array}$ & $\begin{array}{l}\text { Powder } \\
(0.294 \mathrm{~mm})\end{array}$ & $\begin{array}{l}\text { Medium Small } \\
(1.85 \mathrm{~mm})\end{array}$ & $\begin{array}{l}\text { Medium Large } \\
(3.02 \mathrm{~mm})\end{array}$ & $\begin{array}{l}\text { Large } \\
(9.29 \mathrm{~mm})\end{array}$ \\
\hline $\begin{array}{l}\text { Average Thermal } \\
\text { conductivity }(\mathrm{W} / \mathrm{m}-\mathrm{K})\end{array}$ & 2.910 & 2.926 & 3.015 & 2.897 \\
\hline Confidence & 0.261 & 0.240 & 0.059 & 0.102 \\
\hline STDEV & 0.231 & 0.213 & 0.053 & 0.090 \\
\hline
\end{tabular}

Knowing that thermal conductivity was not influenced by the grain sized seen in these ranges alleviates some concerns of the grain size influencing the thermal conductivities of the rock cutting samples from the Marion county well.

Of the samples taken from the Marion County well, seventeen values matched with values from COSUNA pipeline measurements and values determined by Frone. [51] Table 7 provides a comparison of the estimated values of thermal conductivities for the Appalachian Basin to values calculated using a PEDB system on rock cuttings from Marion County Well \#244. 
Table 7. Comparison of existing thermal conductivity estimates (COSUNA and Frone et al) to thermal conductivities performed on Marion County \#244well rock cuttings.

\begin{tabular}{|c|c|c|c|c|c|c|}
\hline $\begin{array}{l}\text { Cutting } \\
\text { Depth } \\
\text { (ft) }\end{array}$ & $\begin{array}{l}\text { Stratigraphic } \\
\text { Age }\end{array}$ & Formation & $\begin{array}{l}\text { COSUNA by } \\
\text { Depth } \\
(\mathrm{W} / \mathrm{m}-\mathrm{K})\end{array}$ & $\begin{array}{l}\text { COSUNA by } \\
\text { Formation } \\
(\mathrm{W} / \mathrm{m}-\mathrm{K})\end{array}$ & $\begin{array}{l}\text { Frone [51] } \\
(\mathrm{W} / \mathrm{m}-\mathrm{K})\end{array}$ & $\begin{array}{l}\text { WVU } \\
(\mathrm{W} / \mathrm{m}-\mathrm{K})\end{array}$ \\
\hline $\begin{array}{c}450- \\
500\end{array}$ & Mississippian & $\begin{array}{c}\text { Start } \\
\text { Mississippian age } \\
(466 \mathrm{ft})\end{array}$ & 2.59 & 1.60 & 1.60 & 1.55 \\
\hline $\begin{array}{l}750- \\
850\end{array}$ & Mississippian & $\begin{array}{l}\text { Big Lime and/or } \\
\text { Greenbrier Gp. } \\
\text { (also limestone) }\end{array}$ & 2.59 & 2.71 & 2.71 & 3.30 \\
\hline $\begin{array}{c}850- \\
950\end{array}$ & Mississippian & Big Injun undiff. & 2.59 & -- & 4.27 & 3.77 \\
\hline $\begin{array}{l}6900- \\
7000\end{array}$ & $\begin{array}{c}\text { Middle } \\
\text { Devonian }\end{array}$ & $\begin{array}{l}\text { Tully and } \\
\text { Onondaga } \\
\text { Limestone } \\
\end{array}$ & 2.46 & 2.91 & 2.91 & 2.19 \\
\hline $\begin{array}{l}7400- \\
7500\end{array}$ & $\begin{array}{c}\text { Lower } \\
\text { Devonian }\end{array}$ & $\begin{array}{l}\text { Oriskany, } 25 \mathrm{~m} \\
\text { Helderberg }\end{array}$ & 2.91 & 4.27 & 4.27 & 2.85 \\
\hline $\begin{array}{l}7900- \\
8100\end{array}$ & $\begin{array}{c}\text { Lower } \\
\text { Devonian }\end{array}$ & Helderberg & 1.96 & -- & 2.72 & 3.44 \\
\hline $\begin{array}{l}10100- \\
10200\end{array}$ & Silurian & Tuscarora SS & 4.15 & 4.15 & 4.15 & 2.03 \\
\hline $\begin{array}{l}10300- \\
10400\end{array}$ & Silurian & $\begin{array}{c}\text { Tuscarora SS, } \\
\text { Juniata, } \\
\text { Ordovician } \\
\end{array}$ & 3.42 & 4.15 & -- & 2.88 \\
\hline $\begin{array}{l}10830- \\
11000\end{array}$ & Silurian & Juniata Fm. & 2.68 & 3.19 & 2.68 & 3.06 \\
\hline $\begin{array}{l}11500- \\
11600\end{array}$ & Silurian & Martinsburg Fm. & 1.68 & 1.68 & 1.5 & 1.98 \\
\hline $\begin{array}{l}11900- \\
12000\end{array}$ & $\begin{array}{c}\text { Trenton } \\
\text { Limestone }\end{array}$ & Martinsburg Fm. & 1.68 & 1.68 & 1.5 & 3.02 \\
\hline $\begin{array}{l}12000- \\
12200\end{array}$ & $\begin{array}{c}\text { Upper } \\
\text { Devonian }\end{array}$ & Martinsburg Fm. & 1.68 & 1.68 & 1.5 & 2.84 \\
\hline $\begin{array}{l}12500- \\
12600 .\end{array}$ & $\begin{array}{c}\text { Trenton } \\
\text { Limestone }\end{array}$ & Martinsburg Fm. & 1.68 & 1.68 & 1.5 & 2.68 \\
\hline $\begin{array}{l}12800- \\
13000\end{array}$ & $\begin{array}{c}\text { Upper } \\
\text { Devonian }\end{array}$ & $\begin{array}{l}\text { Utica Shale, Point } \\
\text { Pleasant Fm. }\end{array}$ & 1.68 & -- & 1.04 & 1.82 \\
\hline $\begin{array}{l}13200- \\
13300\end{array}$ & $\begin{array}{c}\text { Trenton } \\
\text { Limestone }\end{array}$ & $\begin{array}{c}\text { Trenton/BlackRiv } \\
\text { er Group }\end{array}$ & 2.91 & 2.91 & 2.91 & 2.72 \\
\hline $\begin{array}{l}13900- \\
14100 \\
\end{array}$ & $\begin{array}{c}\text { Upper } \\
\text { Devonian }\end{array}$ & St. Paul Group & 2.91 & -- & 3.38 & 2.76 \\
\hline $\begin{array}{l}14400- \\
14500\end{array}$ & $\begin{array}{l}\text { Middle and } \\
\text { Upper } \\
\text { Ordovician } \\
\end{array}$ & St. Paul Group & 2.91 & -- & 3.38 & 3.31 \\
\hline
\end{tabular}


The greatest differences are for the Utica shale (higher conductivity than expected) the Tuscarora sandstone (lower conductivity than expected) the Martinsburg formation (higher conductivity than expected) and the St. Paul group (lower conductivity than expected). Frone in 2014 examined the work of Carter et al (1998) and Gallardo et al (1999) in order to better explain the thermal regime of the Oklahoma portion of the sedimentary Anadarko Basin. [51] Frone used detailed temperature logs, lithology logs, and 250 thermal conductivity measurements heat flow and the present thermal structure of the basin. Since the Appalachian Basin has few real thermal conductivity value records, thermal conductivities in Frone's work, and for the COSUNA columns, were based off of estimates founds in similar lithographic formations in different basins, therefore explaining some of the discrepancies seen in the results.

In addition, values may be a result of in-basin vs. out-of-basin conductivities. It has been known that depth can impact thermal conductivity. As the depth increases, the increase in pressure can increase thermal conductivity, while temperature attainable by drilling may result in a decrease in thermal conductivity. [23] According to Pribnow et al, for crystalline rocks, the observed effect of pressure is less than $1 \%$ per kilometer, while the observed decrease with temperature can be $10 \%$ or more per kilometer, depending on the matrix properties and temperature gradients. Therefore, in order to determine the in situ thermal conductivity of the sample, correction values might be necessary, especially for deep well systems. Thermal conductivity can be taken as a combination of lattice conductivity (or photon conductivity), which is the result of thermal vibration in a crystalline lattice, and radiative conductivity, which is produced by infrared electromagnetic waves. [52] Radiative conductivity can be considered negligible when compared to lattice conductivity for temperatures less than $500^{\circ} \mathrm{C}$. Authors Lee and Deming proposed a generalization that for rock and mineral thermal conductivities higher 
than $2.0 \mathrm{~W} / \mathrm{m}-\mathrm{K}$ at room temperature, the observed thermal conductivity for in situ rock would decrease with increasing temperature, like those samples with conductivities less than $2.0 \mathrm{~W} / \mathrm{m}$ K would increase with increasing temperature. Although correction methods have been developed to correlate the in laboratory thermal conductivity to in situ thermal conductivity by means of an inverse temperature relation of the well temperature, there is yet to be a method which satisfactorily provided accurate values for all points of depth. Unfortunately, isolating which factor most heavily influence the thermal conductivity will would be difficult to determine without more measurements from Appalachian Basin formations.

\section{Conclusions}

Low temperature geothermal systems have the potential to provide abundant, clean, costcompetitive energy for residential, commercial and manufacturing sectors alike. When compared to fossil fuels, such as natural gas, the long term benefit in terms of cost and carbon footprint can be impressive. Ball State University in Muncie, Indiana recently converted to geothermal energy and has projected to save approximately $\$ 2$ million annually, while heating and cooling 47 buildings. [53] As of April 2016, the commodity cost for natural gas was $\$ 2.13 / \mathrm{MMBTU}$ and coal priced at $\$ 2.16 / \mathrm{MMBTU}$. [54,55] However, using this solely as a form of comparison can be a bit deceiving. The cost of natural gas intended for use by commercial and residential sectors includes several factors, including transmission costs and distribution costs, in addition to the cost of the natural gas itself. [56] Examining natural gas specifically, less than half of the total cost of the gas for residential and some commercial users is the cost of the natural gas only. 
Seasonal fluctuations in demand may be result in changes to cost components, but since the price of gas includes fixed cost components in transmission and distribution, regardless of the level of consumption, residential users may see an increase in per unit cost, despite there being a decrease overall in costs. In 2015, residential consumer prices for natural gas experienced a high of $\$ 17.22 / \mathrm{MMBTU}$ (with average cost for the year \$10.64/MMBTU) and commercial consumer prices reached highs of $\$ 8.71 / \mathrm{MMBTU}$ (with average cost for the year $\$ 8.18 / \mathrm{MMBTU}$ ). [57]

As policies change in 2020, industries will be looking for methods and technologies that allow them to continue manufacture good while meeting the newly set carbon dioxide limitations. With industrial demand included in the GEOPHIRES model, the estimated cost for a EGS system is becoming more competitive and more appealing. Universities, colleges and military bases have large floor heating and cooling demands, however to take advantage of geothermal energy, many of these areas would require massive technological and infrastructure renovations to accommodate this new energy source. Some universities, such as West Virginia University, take utilize a steam/water heat exchanger technology that, with minimal modification, successfully be converted to a geothermal system. In this model, every US census 'place' with a high education system was assumed to have at least one school that contained a heating/cooling system that could be easily converted to geothermal technology. While an optimistic approach, more involved examination of the existing heating and cooling systems for key universities and college should be determine, and factors such as total heated/cooled floor space and capabilities of existing equipment run through an Aspen Plus program to calculate school specific surface capital cost to improve the accuracy of the LCOH estimations.

Lithostratigraphic information can be found via the United States Geological Survey geologic

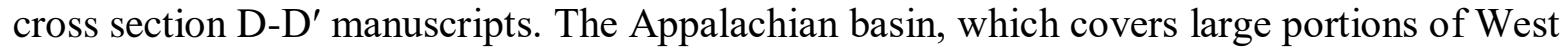


Virginia, Pennsylvania and New York, as well as smaller sections of other states, has been analyzed from the Findlay arch in northwestern Ohio to the Valley and Ridge province in eastern West Virginia based on 13 deep drill holes. Since the Appalachian Basin lacks a library of measured thermal conductivity values, thermal conductivities for heat flow models have been based off of estimates for thermal conductivities founds in similar lithographic formations in different basins. This work found thermal conductivities of rock cuttings collected from Well \#244 in Marion County, WV to a depth of 17,000 ft. Discrepancies between calculated values and those from estimates can be due to incongruities in basin geology or impact of depth factors (temperature and pressure). To determine the predominate factor, more thermal conductivities within the Appalachian Basin formations will be beneficial for accurate future heat flow modeling. 


\section{References}

[1] Conti, John et al. "Annual Energy Outlook 2015." U.S. Energy Information Administration, 1 Apr. 2015. <http://www.eia.gov/forecasts/aeo/pdf/0383(2015).pdf〉.

[2] "U.S. Energy Information Administration - EIA - Independent Statistics and Analysis." International Energy Outlook 2014. 9 Sept. 2014.

[3] "U.S. Energy Information Administration - EIA - Independent Statistics and Analysis." EIA Projects World Energy Consumption Will Increase 56\% by 2040. 25 July 2013.

[4] "U.S. Energy Information Administration. International Energy Outlook 2013. July 2013.

[5] "Paris Agreement." - European Commission. Dec. 2015. <http://ec.europa.eu/clima/policies/international/negotiations/paris/index_en.htm

[6] "How Gas Turbine Power Plants Work." How Gas Turbine Power Plants Work. US Department of Energy - Division of Fossil Energy, 2015.

[7] "Methods for Calculating Efficiency." Combined Heat and Power (CHP) Partnership. Environmental Protection Agency, 2015.

[8] Lund, J.W. "Direct Utilization of Geothermal Energy." Energies 3 (2010): 1443-471. Print.

[9] Fox, Don B., Daniel Sutter, and Jefferson W. Tester. "The Thermal Spectrum of Lowtemperature Energy Use in the United States." Energy \& Environmental Science Energy Environ. Sci. (2011): 3731.

[10] Holm, Alison, Leslie Blodgett, and Dan Jennejohn. "Geothermal Energy and Greenhouse Gas Emissions." Geothermal Energy Association, Nov. 2012.

[11] "A History of Geothermal Energy in America." A History of Geothermal Energy in America. US Department of Energy - Office of Energy Efficiency \& Renewable Energy, 2015.

[12] Holm, Alison, Leslie Blodgett, Dan Jennejohn, and Karl Gawell. "Geothermal Energy: International Market Update." 1 May 2010.

[13] Ellabban, Omar, Haitham Abu-Rub, and Frede Blaabjerg. "Renewable Energy Resources: Current Status, Future Prospects and Their Enabling Technology." Renewable and Sustainable Energy Reviews 39 (2014): 748-64.

[14] Augustine, Chad, Jefferson W. Tester, and Brian Anderson. "A COMPARISON OF GEOTHERMAL WITH OIL AND GAS WELL DRILLING COSTS." 7PROCEEDINGS, Thirty-First Workshop on Geothermal Reservoir Engineering. 
[15]"Renewables." Geothermal. International Energy Agency, 2014.

<https://www.iea.org/topics/renewables/subtopics/geothermal/>.

[16] Lienau, P. J., and J. W. Lund. REFERENCE BOOK ON GEOTHERMAL DIRECT USE.

Klamath Fall. Oregon Institute of Technology, 1994. Print.

[17] SURFACE HEAT FLOW FOR REGIONAL GEOTHERMAL RESOURCE ASSESSMENT." PROCEEDINGS, Thirty-Seventh Workshop on Geothermal Reservoir Engineering (2012).

[18] Tester, Jeff, Tim Reber, Koenraad Beckers, Maciej Lukawski, Erin Camp, Gloria Aguirre, Terry Jordan, and Frank Horowitz. "Integrating Geothermal Energy Use into Re-building American Infrastructure." Proceedings World Geothermal Congress 2015 (2015).

[19] Reber, Timothy J., Koenraad F. Beckers, and Jefferson W. Tester. "The Transformative Potential of Geothermal Heating in the U.S. Energy Market: A Regional Study of New York and Pennsylvania." Energy Policy 70 (2014): 30-44.

[20] "How an Enhanced Geothermal System Works." How an Enhanced Geothermal System Works. US Department of Energy - Office of Energy Efficiency \& Renewable Energy, 2015.

[21] Matsuda, Kazuo. "Low Heat Power Generation System." The Italian Association of Chemical Engineering VOL. 35 (2013). CHEMICAL ENGINEERING TRANSACTIONS.

[22] Midttomme, K., and E. Roaldset. "The Effect of Grain Size on Thermal Conductivity of Quartz Sands and Silts." Petroleum Geoscience 4.2 (1998): 165-72.

[23] Pribnow, Daniel F. C., and John H. Sass. "Determination of Thermal Conductivity for Deep Boreholes." J. Geophys. Res. Journal of Geophysical Research: Solid Earth 100.B6 (1995): 9981-994.

[24] Antriasian, A. M. (2010) Proceedings of the World Geothermal Congress 2010 Bali. (2010).

[25] Stutz, George R., Mitchell Williams, Zachary Frone, Timothy J. Reber, David Blackwell, Teresa Jordan, and Jefferson W. Tester. " A Well by Well Method for Estimating Surface Heat Flow for Regional Geothermal Resource Assessment." Stanford Geothermal Workshop. (2015).

[26] Kutasov, Izzy M., and Lev V. Eppelbaum. "Temperature Regime of Boreholes: Cementing of Production Liners." (2014). 
[27] Blackwell, David D., Petru T. Negraru, and Maria C. Richards. "Assessment of the Enhanced Geothermal System Resource Base of the United States." Natural Resources Research 15.4 (2007): 283-308.

[28] Xiaoning He and Brian Anderson, "Techno-Economic Assessment of a Geothermal District Heating and Cooling System: A Case Study of West Virginia University," Report. (2013)

[29] Ryder, R.T., Crangle, R.D., Jr., Trippi, M.H., Swezey, C.S., Lentz, E.E., Rowan, E.L., and Hope, R.S., Geologic cross section D-D' through the Appalachian basin from the Findlay arch, Sandusky County, Ohio, to the Valley and Ridge province, Hardy County, West Virginia: U.S. Geological Survey Scientific Investigations Map 3067. (2009).

[30] Orlo, E. C., et al. "Correlation of stratigraphic units in North America: Correlation chart series." The American Association of Petroleum Geologists. (1985).

[31] "Official Blog: A New Geothermal Map of the United States." Google Green Blog. Google.org, 1 Oct. 2011. <http://blog.google.org/2011/10/new-geothermal-map-ofunited-states.html>.

[32] Reber, T., Tester, J. "Evaluating Opportunities For Enhanced Geothermal System-Based District Heating In New York And Pennsylvania". Master's Thesis. Cornell University. (2013)

[33] Rasband, W.S., ImageJ, U. S. National Institutes of Health, Bethesda, Maryland, USA, http://imagej.nih.gov/ij/, 1997-2015.

[34] "Geothermal Maps." NREL: Dynamic Maps, GIS Data, and Analysis Tools -. National Renewable Energy Laboratory, 1 June 2015.

[35] Costain, J. K., L. Glover, and A. K. Sinha. "Low-temperature Geothermal Resources in the Eastern United States." Eos Trans. AGU Eos, Transactions American Geophysical Union 61.1 (1980): 1.

[36] Shope, Elaina N., Timothy J. Reber, George R. Stutz, Gloria A. Aguirre, Teresa E. Jordan, and Jefferson W. Tester. "GEOTHERMAL RESOURCE ASSESSMENT: A DETAILED APPROACH TO LOW-GRADE RESOURCES IN THE STATES OF NEW YORK AND PENNSYLVANIA." PROCEEDINGS, Thirty-Seventh Workshop on Geothermal Reservoir Engineering (2012).

[37] Dairy Plants USA Directory. (n.d.) from http://www.dairyfoods.com/dairyplantsusa

[38] EIA. 2006 MANUFACTURING ENERGY CONSUMPTION SURVEY (MECS). 
https://www.eia.gov/consumption/manufacturing/data/2006/ (2006).

[30] Beckers, Koenraad F. "GEOPHIRES V1.2." GEOPHIRES V1.2.

<http://koenraadbeckers.net/geophires/index.php> (2013).

[31] Shaalan, H. E. "Generation of Electric Power." Chapter 8 from Handbook of Electric Power Calculations. Beaty, H. W., editor. 3rd edition. McGraw-Hill (2001).

[32] Rushing, A. S., Kneifel, J. D., and Lippiatt, B. C. Energy Price Indices and Discount Factors for Life-Cycle Cost Analysis - 2011. Annual Supplement to NIST Handbook 135 and NBS Special Publication 709. U.S. Department of Commerce Technology Administration National Institute of Standards and Technology. September 2011. NISTIR 85-3273-26 (2011).

[33] Census Bureau. 2007 North American Industry Classification System. www.census.gov/cgi-bin/sssd/naics/naicsrch?chart=2007 (2007).

[35] Census Bureau. American Community Survey 5-year Estimates. Accessed online via American Fact Finder. factfinder2.census.gov/faces/nav/jsf/pages/index.xhtml (2011b).

[36] Census Bureau. 2007 Economic Census. Accessed online via American Fact Finder. factfinder2.census.gov/faces/nav/jsf/pages/index.xhtml (2011c).

[37] Census Bureau. (2012). “Census 2000 Geographic Definitions.” Revised March 2012. www.census.gov/geo/www/geo defn.html

[38] EIA. 2001 Residential Energy Consumption Survey. Table CE2-6.2u and CE4-6.2u. www.eia.gov/consumption/residential/data/2001/index.cfm?view=consumption (2001).

[39] EIA. 2003 Commercial Buildings Energy Consumption Survey. Tables B1, B19, $\mathrm{C} 3$, and $\mathrm{E} 2$. www.eia.gov/emeu/cbecs/cbecs2003/detailed tables 2003/detailed tables 2003.html (2006).

[40] EIA. 2009 Residential Energy Consumption Survey. Table HC10.10. www.eia.gov/consumption/residential/data/2009/ (2009).

[41] EIA. Description of CBECS Building Types. www.eia.gov/emeu/cbecs/building types.html (2012).

[51] Frone, Z. Tester, J. "Heat Flow and Thermal History of the Anadarko Basin, Oklahoma". Southern Methodist University. Search and Discovery Article \#10657 (2014). 
[52] Lee, Youngmin, and David Deming. "Evaluation of Thermal Conductivity Temperature Corrections Applied in Terrestrial Heat Flow Studies." J. Geophys. Res. Journal of Geophysical Research: Solid Earth 103.B2: 2447-454. (1998).

[53] "Going Geothermal." Geothermal Energy System - Ball State University. (2016). $<\mathrm{http}: / / \mathrm{cms}$.bsu.edu/about/geothermal>

[54] "U.S. Energy Information Administration - EIA - Independent Statistics and Analysis." Today in Energy. (2016) <http://www.eia.gov/todayinenergy/prices.cfm>.

[55] "Natural Gas Monthly - Table 3. Selected National Average Natural Gas Prices, 20112016." U.S. Energy Information Administration, 2016.

[56] "Why Do Natural Gas Prices Fluctuate So Much?" Natural Gas Annual. Energy Information Administration.

http://www.eia.gov/pub/oil_gas/natural_gas/analysis_publications/why_do_prices_fluctuate/html/ngbro.html

[57] "U.S. Price of Natural Gas Delivered to Residential Consumers (Dollars per Thousand Cubic Feet)." U.S. Price of Natural Gas Delivered to Residential Consumers (Dollars per Thousand Cubic Feet). (2016). https://www.eia.gov/dnav/ng/hist/n3010us3m.htm. 


\section{Appendix A - Standard Operating Procedure for HDR Portable Electronic Divided Bar (PEDB)}

\section{General background}

The PEDB measures thermal conductivity, a physical property which controls the rate at which heat energy flows through a material, in this instance rock cores or cuttings, in a given thermal gradient. Units placed on this property are watts per meter-Kelvin (W/m$\mathrm{K})$. For this system, PEDB is designed for samples saturated with water prior to analysis.

For questions concerning equipment repair or calibration, reach out to Anson Antriasian at Hot Dry Rocks (anson.antriasian@hotdryrocks.com)

\section{Excel Data Entry}

a. See Example Excel on desktop labeled "New Excel Form for PEDB"

Open and see two sheets, one labeled "thermal conductivity" and the second "sample analysis"

\section{Sample Preparation}

a. For determining thermal conductivity of empty hollow cells (STEP 1)

i. Record the cell properties in Excel sheet labeled "thermal conductivity". This Excel sheet has calibration constants which are used for calculating purposes. Since you are using a hollow cell, copy the row labeled "ROUND" and paste (so that the functions in the cells still work) lower down in the sheet. If you are using irregularly shaped samples, then you would copy the row that says "irregular".

Follow the steps in 4 a-d to turn on the machine and follow steps in sections 5 and 6 for analysis.

Recommendations:

a) In Column A, record sample well depth/depth range.

b) In Column B, record the hollow cell being used (small A, medium $\mathrm{F}$, etc)

c) In Column C, record the thickness of the SAMPLE! Each lid enters the cell by $3 \mathrm{~mm}$ or so, therefore measure the indent on the lid (around 6 $\mathrm{mm}$ total) and subtract from the total thickness of the hollow cell.

d) In Column D, it calculates surface area for you. DON'T MESS WITH THE FUNCTION!

e) Column E, insert $35 \mathrm{~mm}$ for the outer diameter of the hollow cell.

f) Column F is the dT (or the steady state temperature gradient measured by the PEDB). Insert the value here. 
g) Column G-P are calculations/constants/factors set up by the calibration. Again, leave these columns alone.

h) Column Q is the thermal conductivity OF THE WHOLE SET UP (sample, hollow cell, and water). Put this value in "Conductivity of empty cell" if running thermal conductivity of the empty hollow cell.

b. For rock cuttings

i. Record what hollow cell you will be using with which sample in Column $\underline{\text { A. }}$

ii. Record cell dimensions in column $\mathrm{F}$ through $\mathrm{I}$. Column $\mathrm{J}$ and $\mathrm{K}$ are calculations, do not mess with these cells.

iii. Weighed hollow cell and record weight on Excel sheet in Column B

iv. Weigh the sample prior to dehydration, and record in Column C. For rock cuttings, to ensure accurate reading, it is recommended that the samples be dehydrated for 12-24 hours to remove any moisture. Dehydration can be done by putting the sample in a marked hollow cell in a vacuum chamber under house pressure for the designated time, and record the resulting dehydrated weight in Column D.

v. Add dehydrated sample and hollow cell system to a dish of deionized water in a vacuum chamber under house pressure for 12-24 hours to ensure complete saturation.

c. For rock cores

i. Weigh core sample and record weight in Excel form.

ii. Dehydrate the core using a vacuum chamber under house pressure for 1224 hours. Record dehydrated weight in Excel form.

iii. Place

4. Initial Setup

a. The PEDB is powered by a 24-Volt, center tapped DC power supply unit. Turn on power supply first by clicking the rocker switch into the "ON" position on the back of the power supply unit (white box attached to PEDB).

b. Turn the PEDB system itself by positioning the metal toggle switch to the "ON" position located on the face of machine. The display should light up, indicating the system is on and warming up.

c. Set the desired temperature gradient to " $+10,-10 "$ to provide the maximum thermal gradient across the sample.

d. Hot Dry Rocks recommends letting the system equilibrate for 30 minutes before running your samples. I would recommend an hour or two, scheduling allowing.

e. Once the PEDB is equilibrated, remove sample-hollow cell system from water bath and pat dry gently. Record the weight of the water-sample-hollow cell system in the Excel form (Column E).

5. Running Rock Sample 
a. Once the PEDB is equilibrated, wipe the cold plate with a dry towel to remove any moisture that may have formed. Coat the top and bottom lid of the hollow cell with petroleum gel (look in drawer below PEDB) with enough material to cover the entire brass disk and fill the holes in the top lid.

b. Place hollow cell in the middle of the cold plate. Twist the handle on top of PEDB to lower the hot plate onto the lid of the hollow cell. Tighten to the point equivalent to closing a lid to jar.

c. Save file with usable name (EXAMPLE: SmallA_200-300 tells you that you used small cell A and measured depth 200-300.)

d. Hit red triangle to start record, two vertical parallel lines (the pause button) to pause, and the black square to stop. NOTE: if you hit STOP you cannot continue recording after. You will need to create a new save if you want to collect more data.)

e. There is a small icon on the top right that appears to be a small graph. After starting the recording of data, click that miniature graph icon to see the real time data collection graph. You'll need it in the next step.

f. After steady state is reach (the delta $T$ will appear as a flat line), pause the data collection and overlay the mouse to determine the value at that time value (seen in top left of screen). Use this in Column F of your "thermal conductivity" sheet Excel.

g. Excel will the perform a calculation on this value, and give you a thermal conductivity of the WHOLE SYSTEM (rock sample, hollow cell, and water) in Column Q. Put this value in column labeled "Conductivity of full wet cell" under your main excel worksheet "sample analysis". Excel will then use that value, plus the thermal conductivity of the empty cell found using steps and weight of dehydrated and saturated sample to calculate the thermal conductivity of just the rock samples.

h. It is recommended that you perform this process 3 times per sample for later statistical analysis.

6. Clean up

a. Once done with the sample, scrap out rock cuttings into a labeled petri dish and let sit on counter over night to evaporate excess liquid. Once dry, replace into labeled sample pouches and return to box of origin.

b. Rinse hollow cell to remove dirt/grime and use soap, if necessary, to remove excess petroleum gel. Dry thoroughly.

c. Make sure labels are still legible (replace with permanent marker if necessary).

7. For further depth of understanding behind the workings of the PEDB, or for any corrections in equations, please refer to paper material provided by Hot Dry Rocks, discussing the more intricate nature of the equipment, methods of repair, and equation origin and usage. 


\section{Appendix B - Main GEOPHIRES file}

The following MATLAB code is the primary executable MATLAB shell code used in this study.

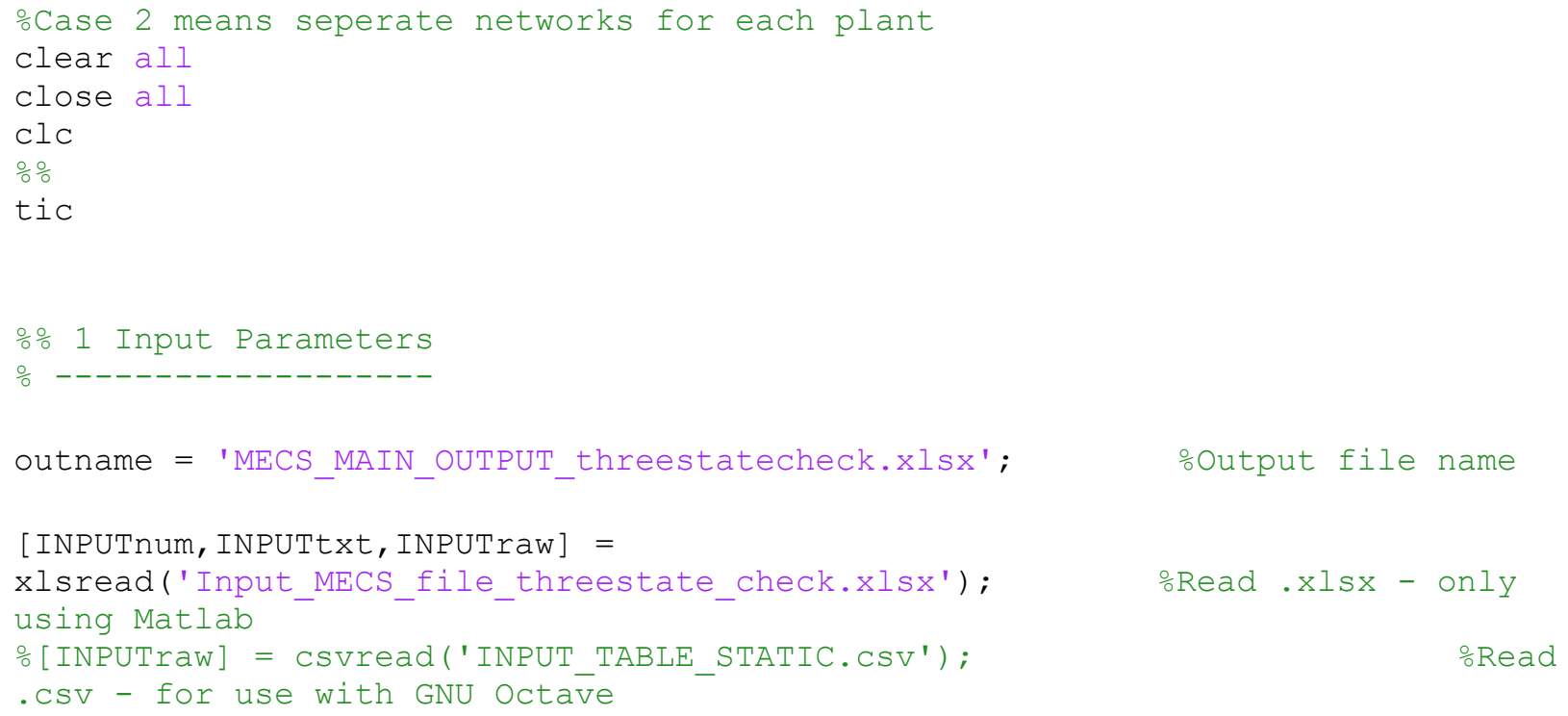




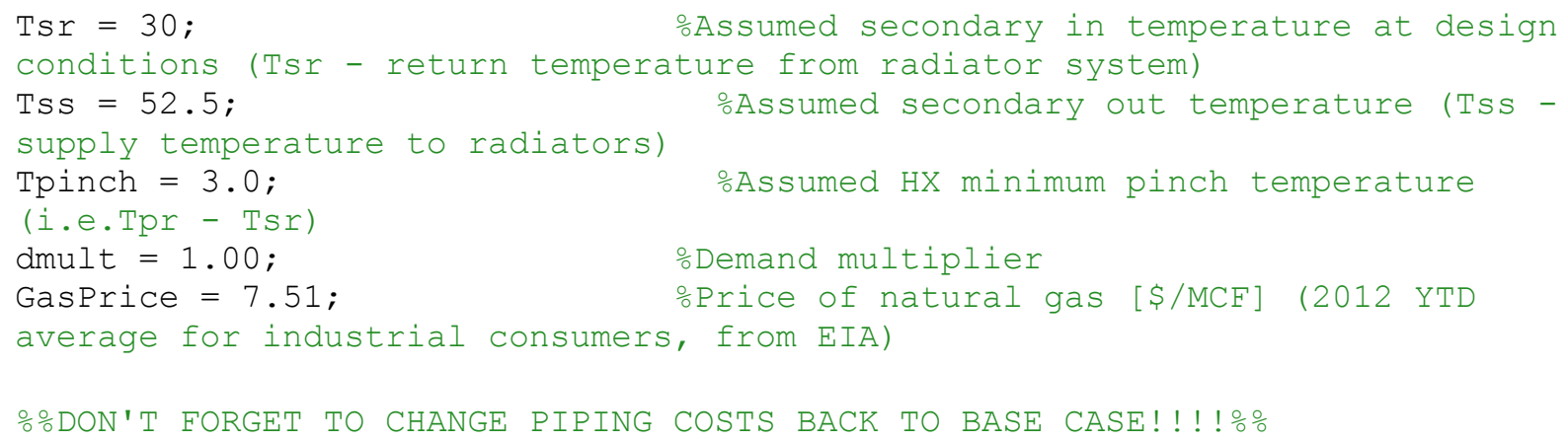




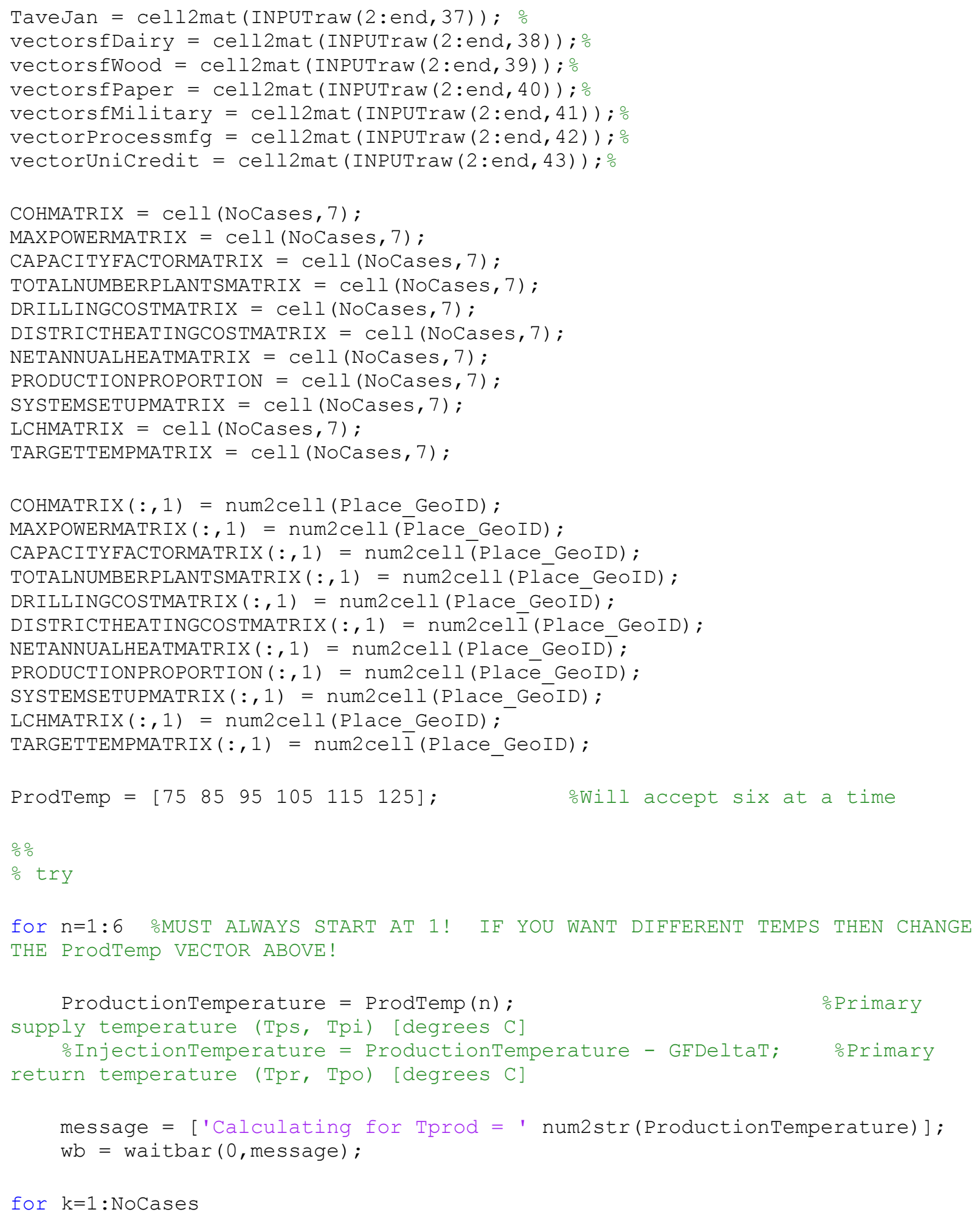




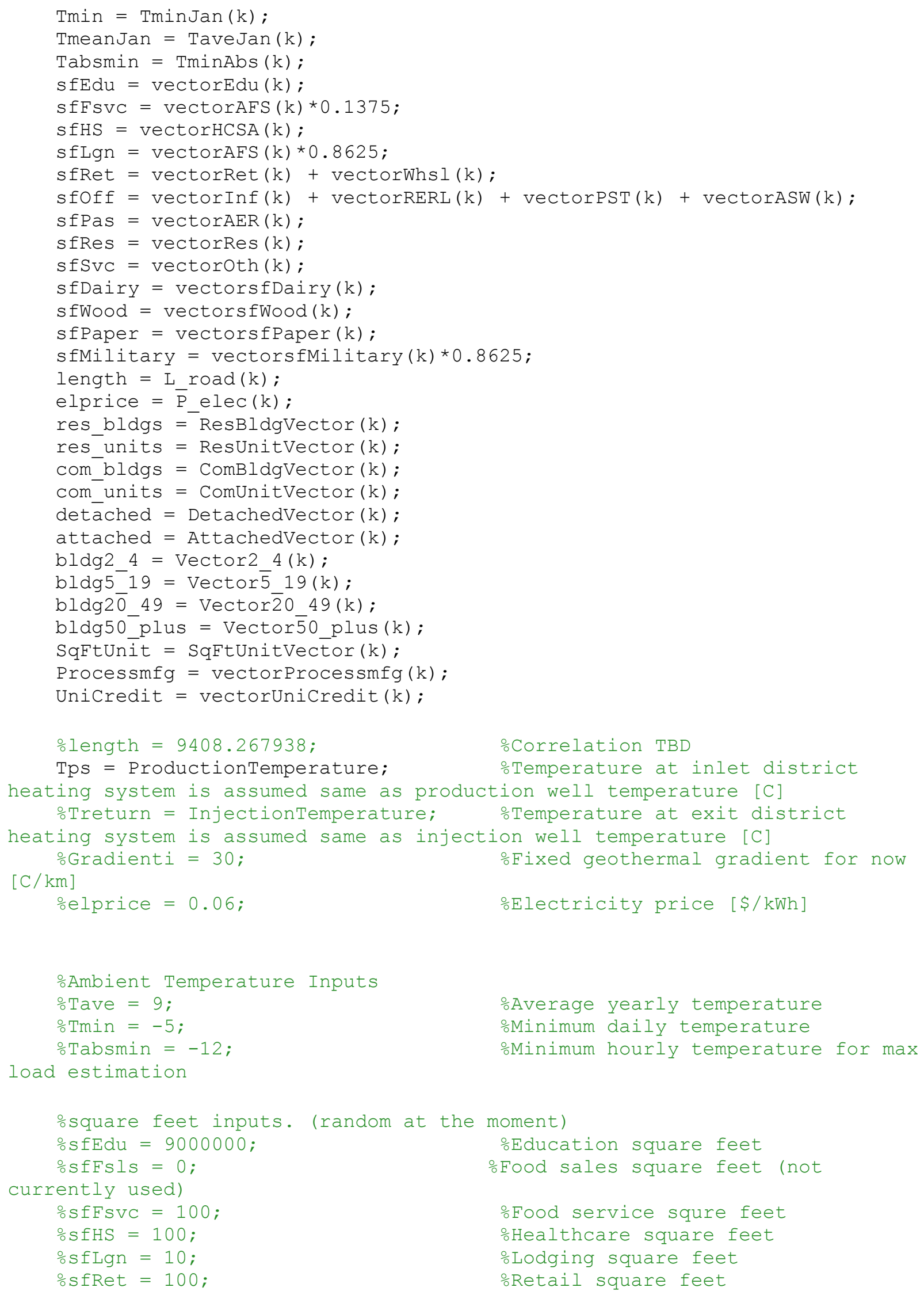




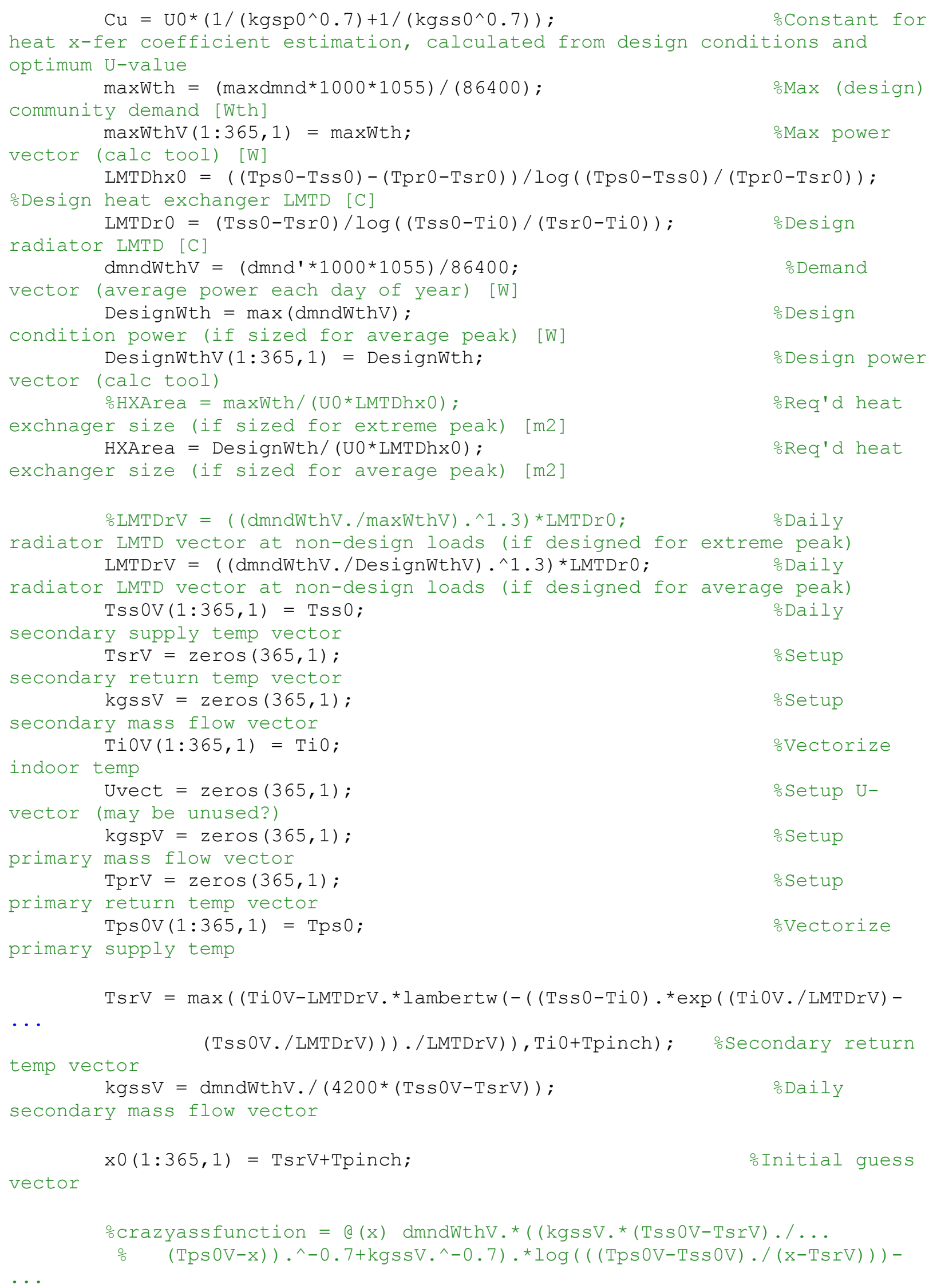




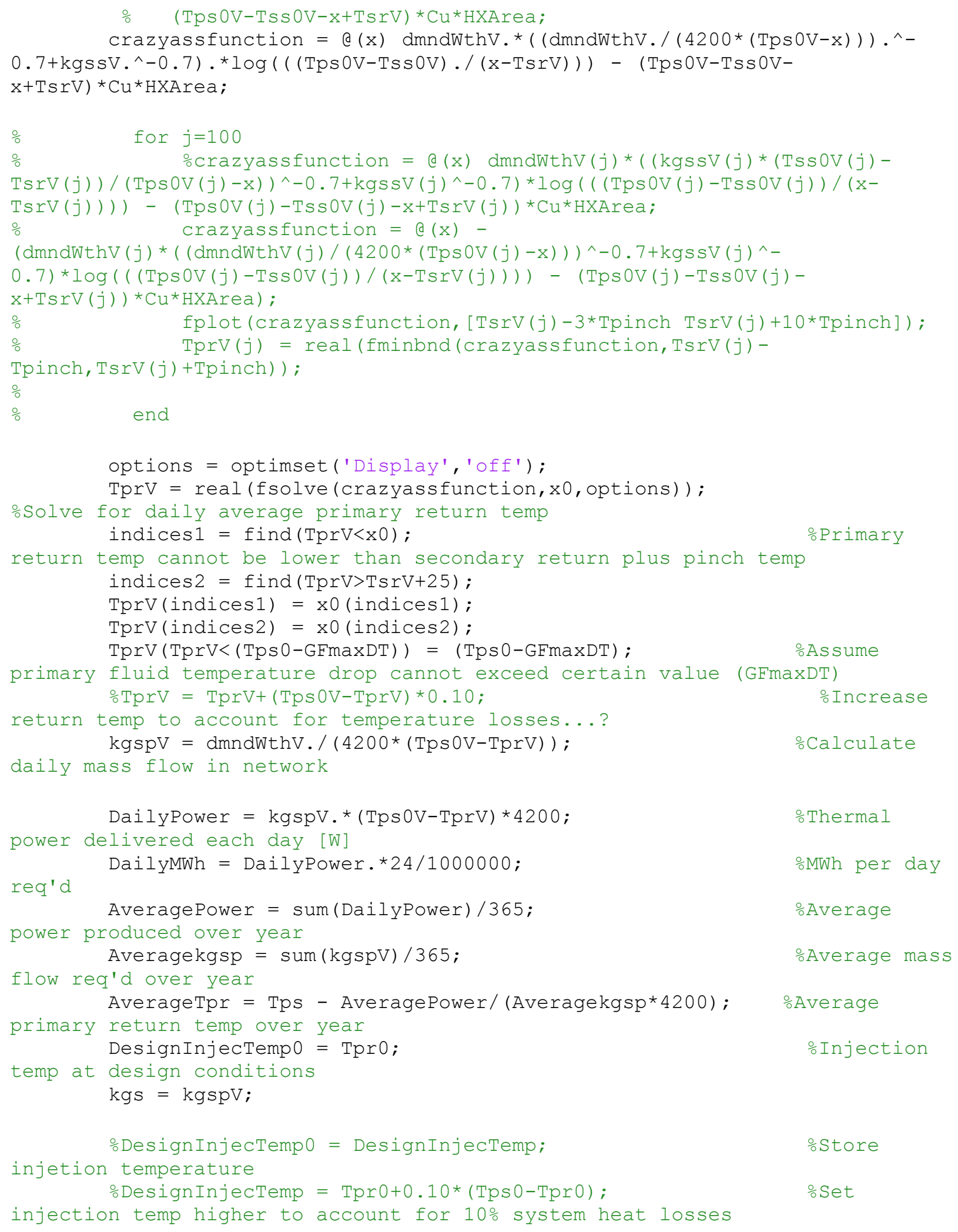


oTransforming to MW and MWh for cost function

otot is yearly average heating demand in MWh

omax is maximum heating demand in MW

otot $=$ yrdmnd*0.293/(1000*365*24)

Qtot $=$ yrdmnd $* 2.931 * 10^{\wedge}-4$;

$\mathrm{Qmax}=\operatorname{maxdmnd}{ }^{\star} 1.221 * 10^{\wedge}-5 ;$

ㅇmnd0 $=\mathrm{dmnd} * 2.931 * 10^{\wedge}-4 ;$

$\because \mathrm{Qmax}=80$;

\%tot $=80 * 8760 * 0.5$;

oInvestmentCost is capital cost for district heating system

operatingCost is yearly O\&M costs for district heating system

\%[InvestmentCost, OperatingCost, PipeDiam, NoPipes, Cdist, PumpIC] = distcostFcn (length, Qtot, Qmax, kgs, Tnetwork, elprice, maintenance, discount, paybac k, MassflowRate) ;

$\mathrm{c}=\mathrm{clock}$;

disp(['--- Date: ', date,' - Time: ', num2str(c(4)), ' : ', num2str(c (5)), ... ': ', num2str (round $(\mathrm{c}(6)))$, ' -- ']);

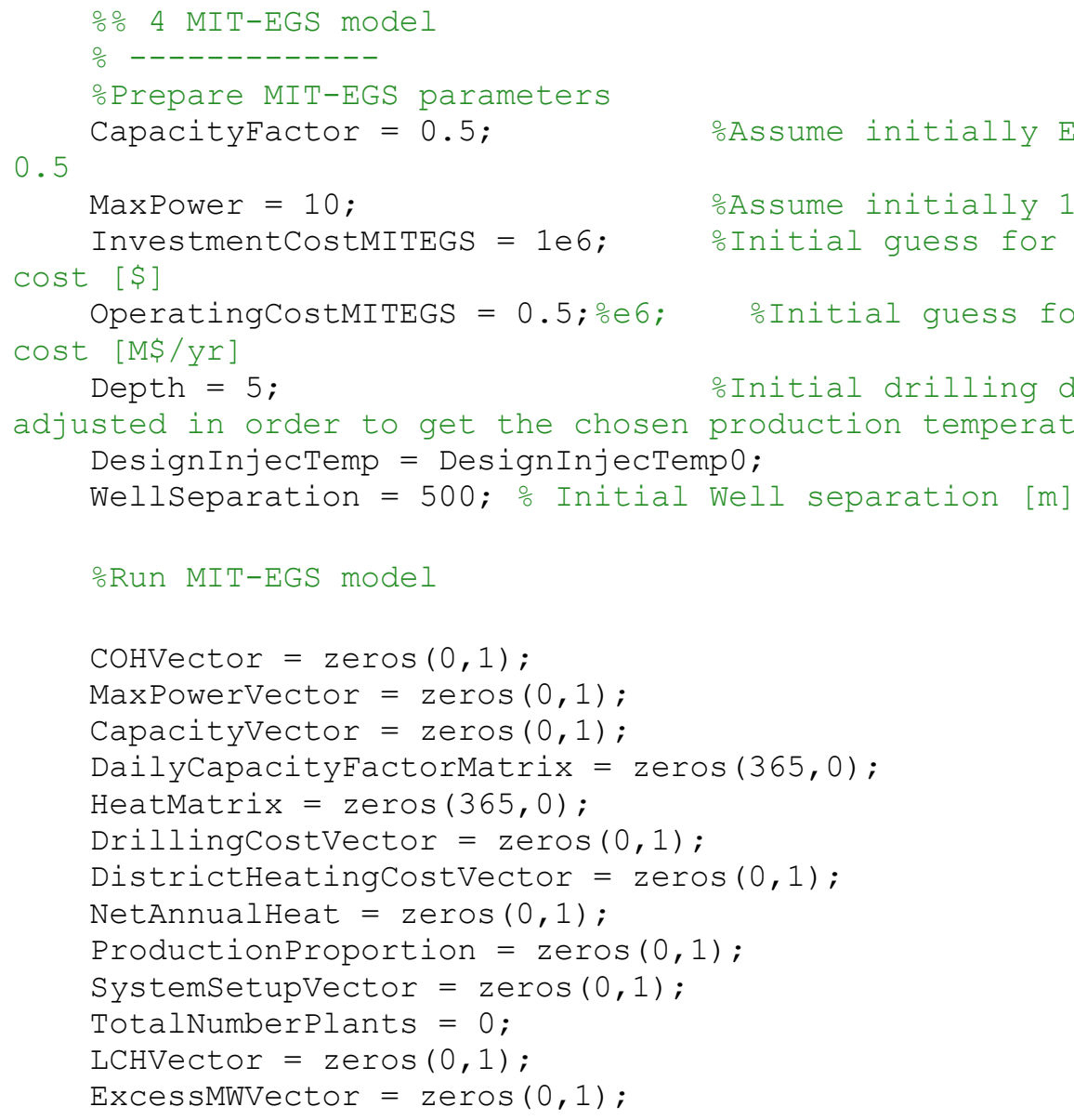




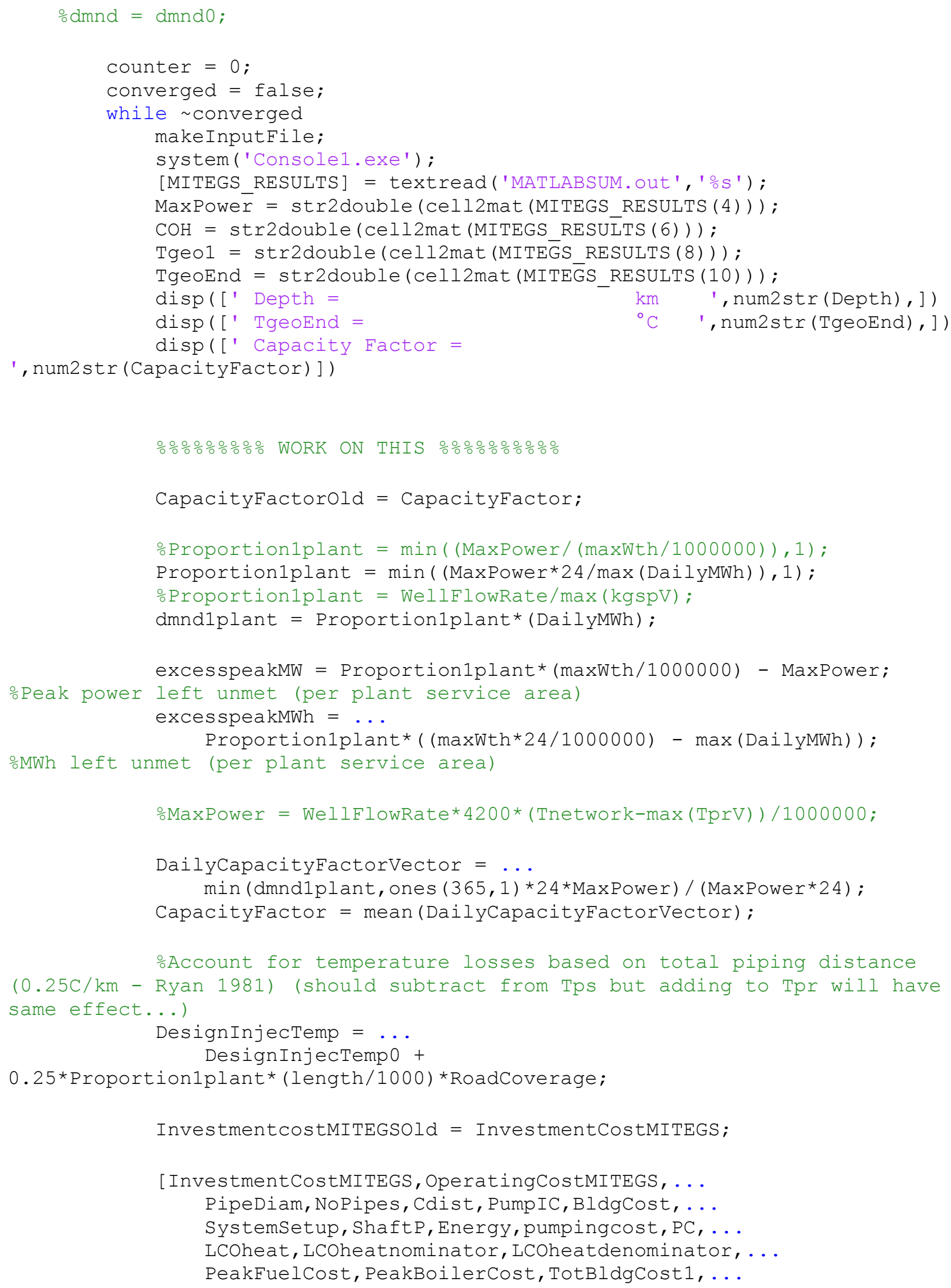


TotBldgCost2,BldgCost1,BldgCost2] = ...

distcostFcn (Proportion1plant, Proportionlplant*length, ... Proportion1plant*Qtot, Proportion1plant*Qmax, ...

Proportionlplant*kgs, Tps, elprice, discount, payback, ... WellFlowRate, BranchDistance, res_bldgs, res_units,... com_bldgs, com_units, detached, attached, bldg 2 4, ... bldḡ5_19,bldḡ̄o_49,bldg50_plus, SqFtUnit, Peā̄UnitDmnd, . . .

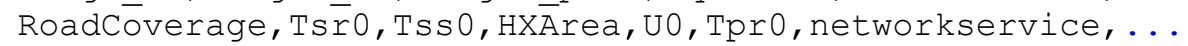
GasPrice, excesspeakMWh); $\frac{\circ}{2} \mathrm{ZF}$ changed excesspeakMW to

excesspeakMWh to fix issue in function

equipment (M\$)

\%InvestmentCostmiteGS is total investment cost of all surface equipment (M\$/yr)

operatingCostMITEGS is yearly operating cost for surface

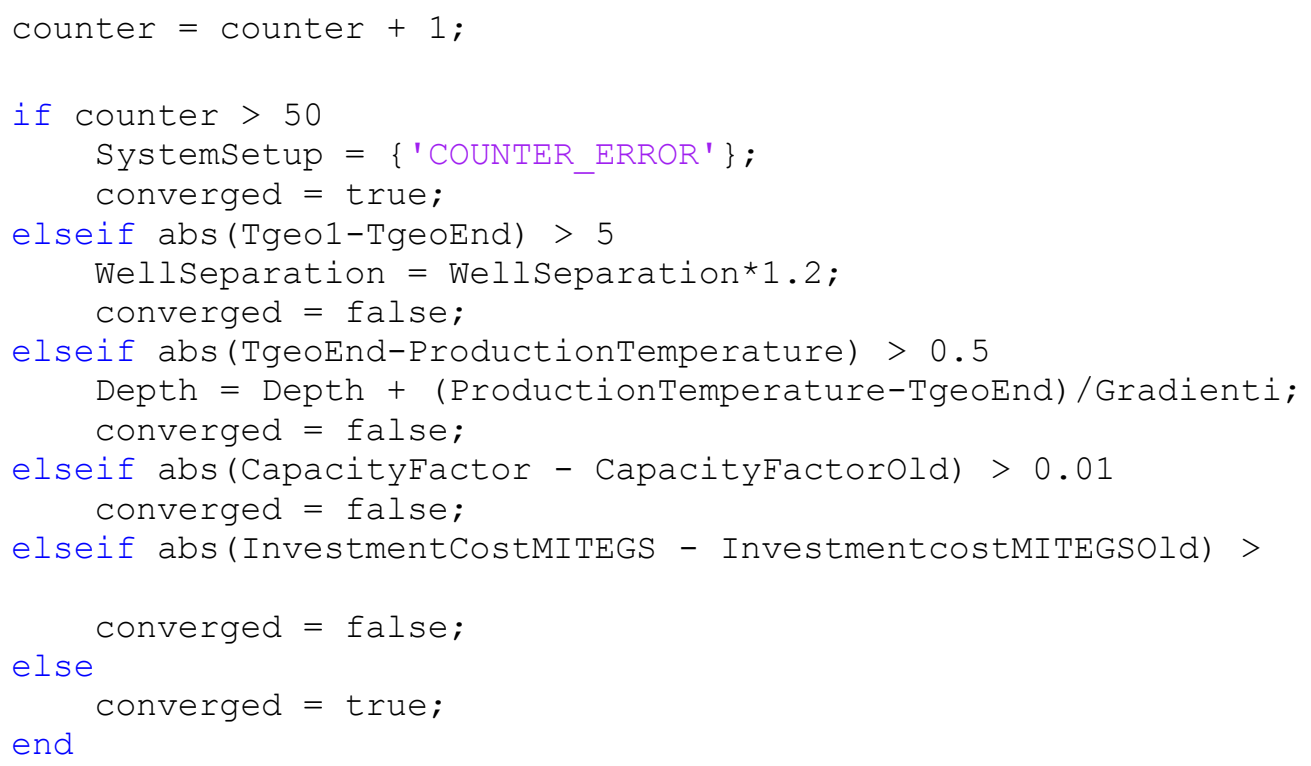

end

osimple discounted cash-flow analysis for estimation of Levelized Cost of Heat ( $\mathrm{LCOH})$

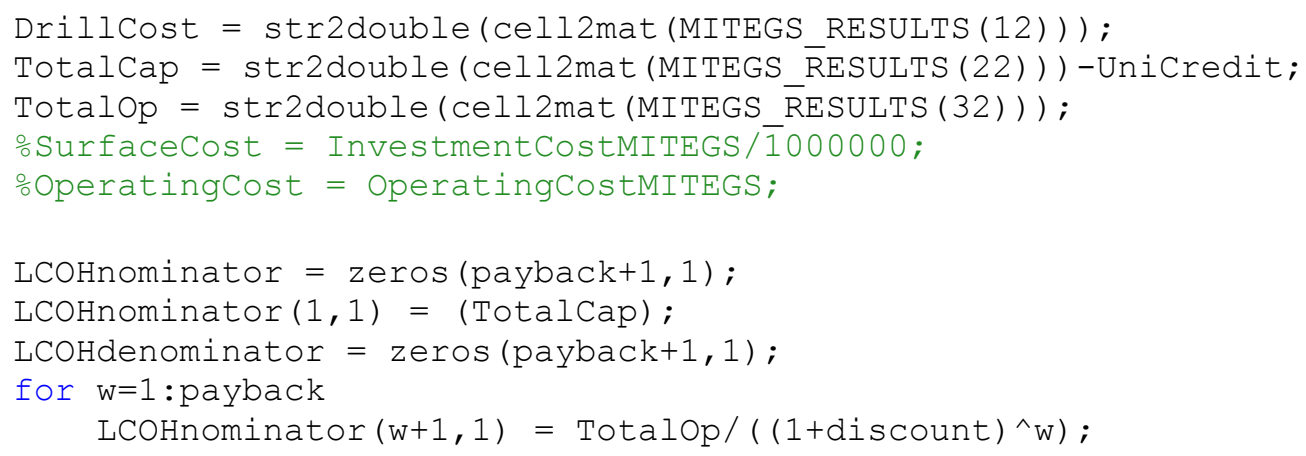




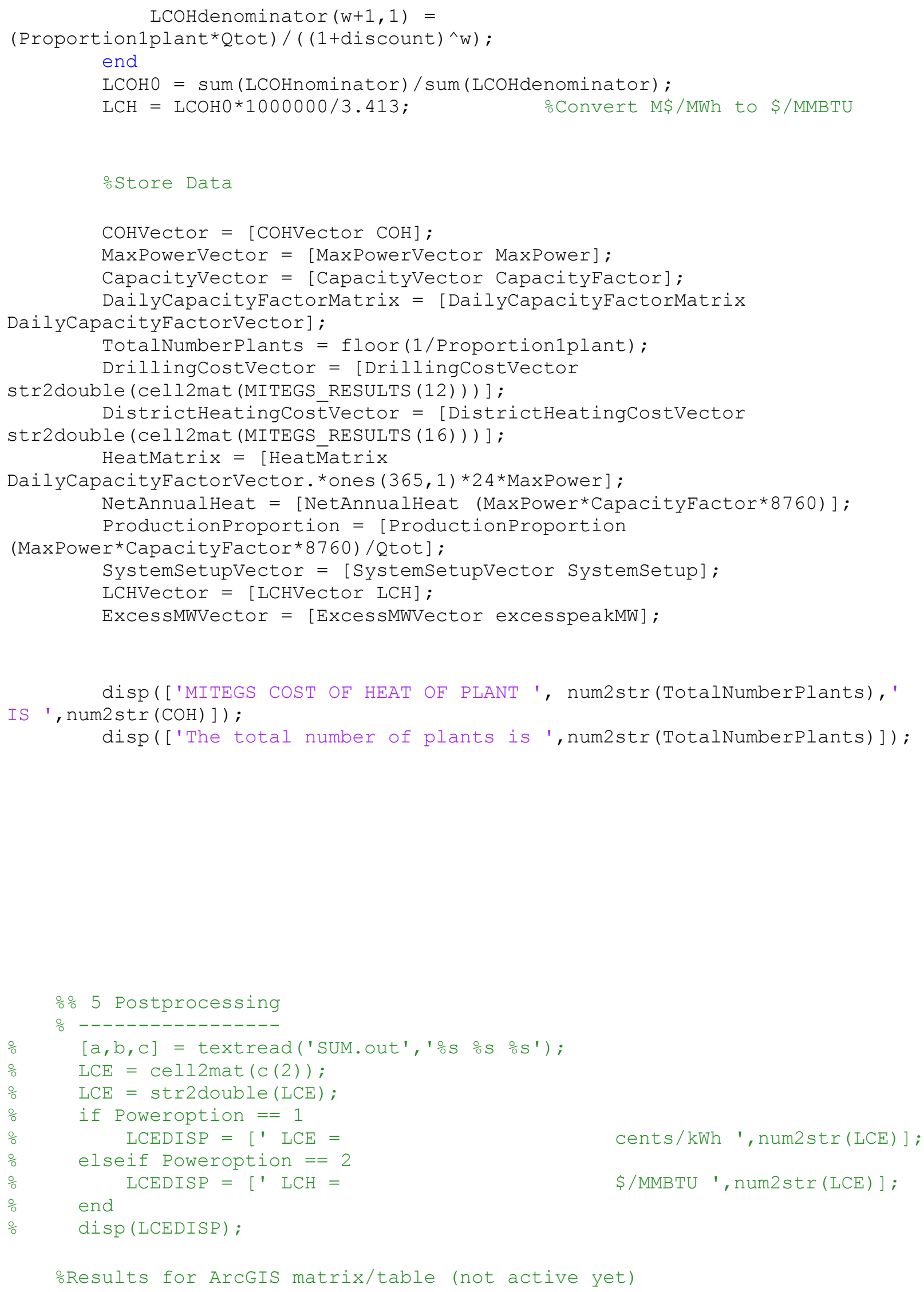




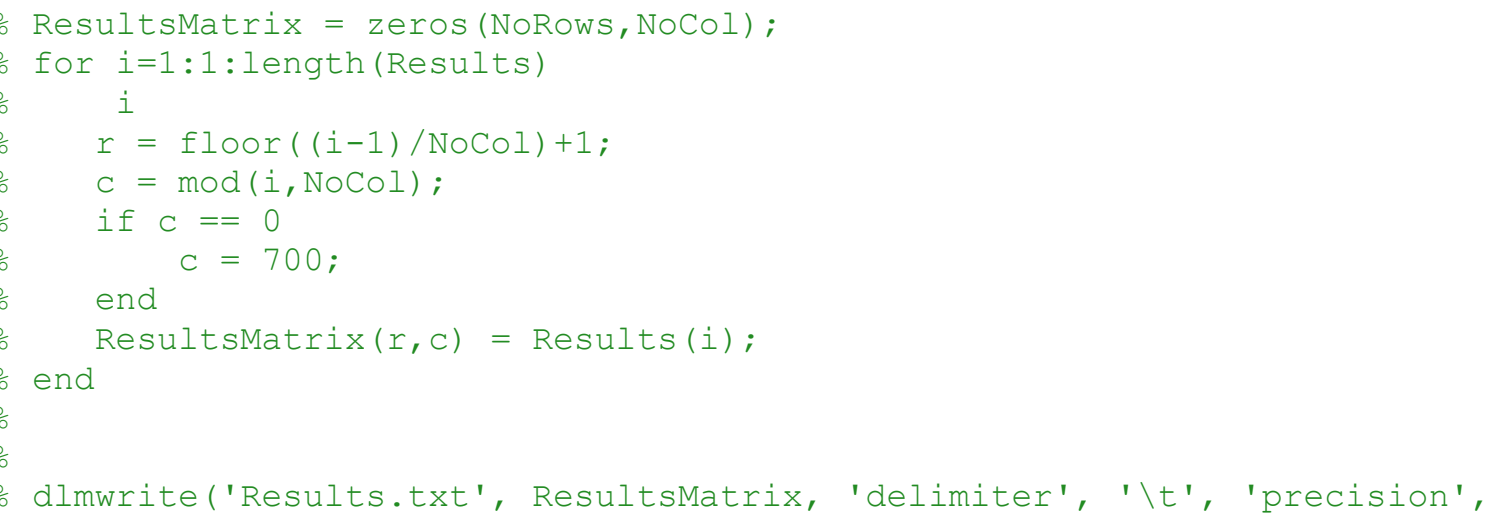

end

oOptimal matrix for LCH calcualted using discounted cash-flow

if LCHVector<cell2mat (LCHMATRIX $(k, n)$ )

$\operatorname{BESTMATRIXLCH}(k, 1)=\operatorname{LCHMATRIX}(k, 1)$;

$\operatorname{BESTMATRIXLCH}(\mathrm{k}, 2)=\operatorname{LCHMATRIX}(\mathrm{k}, \mathrm{n}+1)$;

$\operatorname{BESTMATRIXLCH}(\mathrm{k}, 3)=\operatorname{MAXPOWERMATRIX}(\mathrm{k}, \mathrm{n}+1) ;$

$\operatorname{BESTMATRIXLCH}(k, 4)=$ CAPACITYFACTORMATRIX $(k, n+1)$;

$\operatorname{BESTMATRIXLCH}(k, 5)=$ TOTALNUMBERPLANTSMATRIX $(\mathrm{k}, \mathrm{n}+1)$;

$\operatorname{BESTMATRIXLCH}(k, 6)=\operatorname{TARGETTEMPMATRIX}(k, \mathrm{n}+1) ;$

end 
end

close (wb)

\%Write results to output spreadsheet

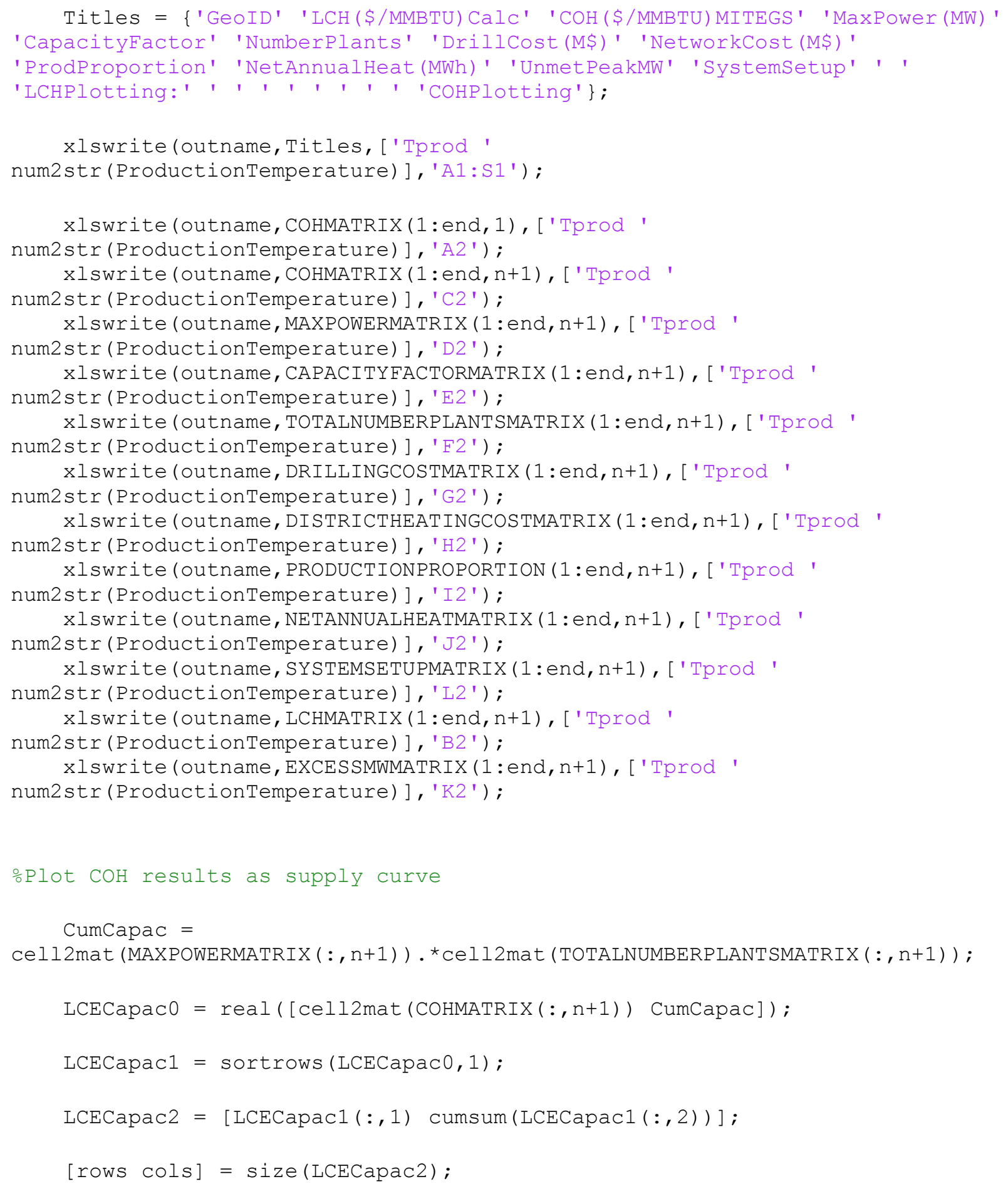




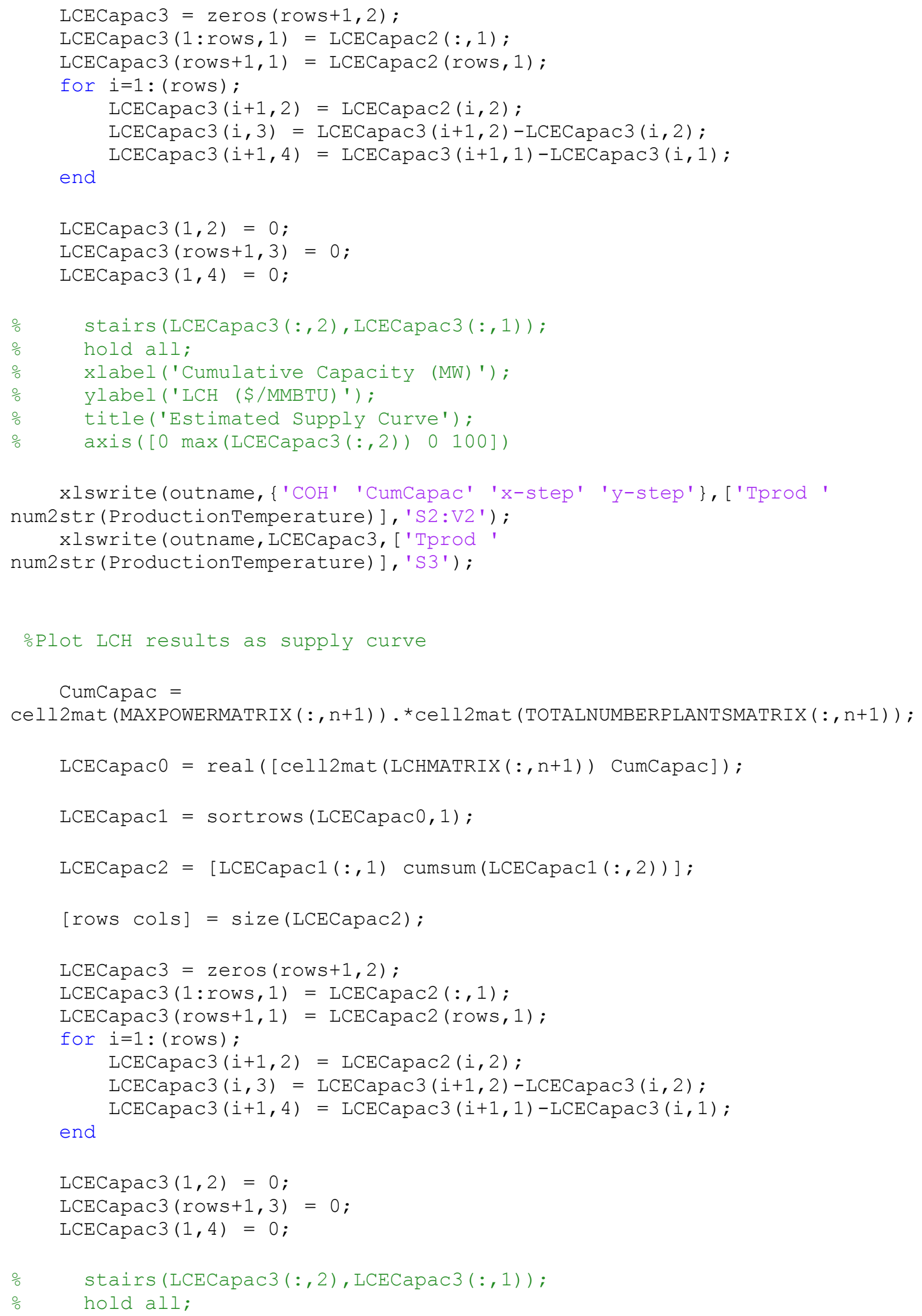




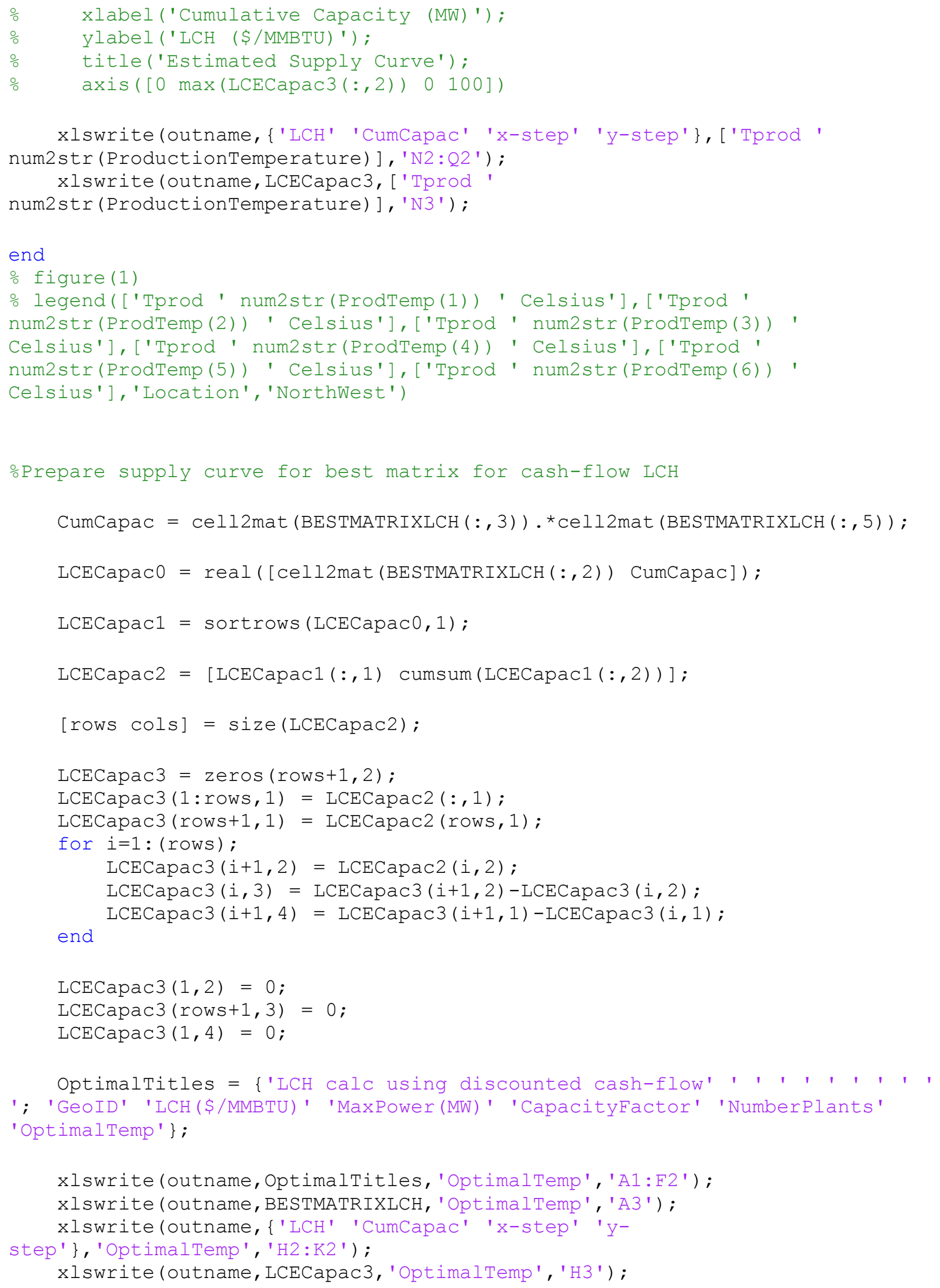


oPrepare supply curve for best matrix for MITEGS COH

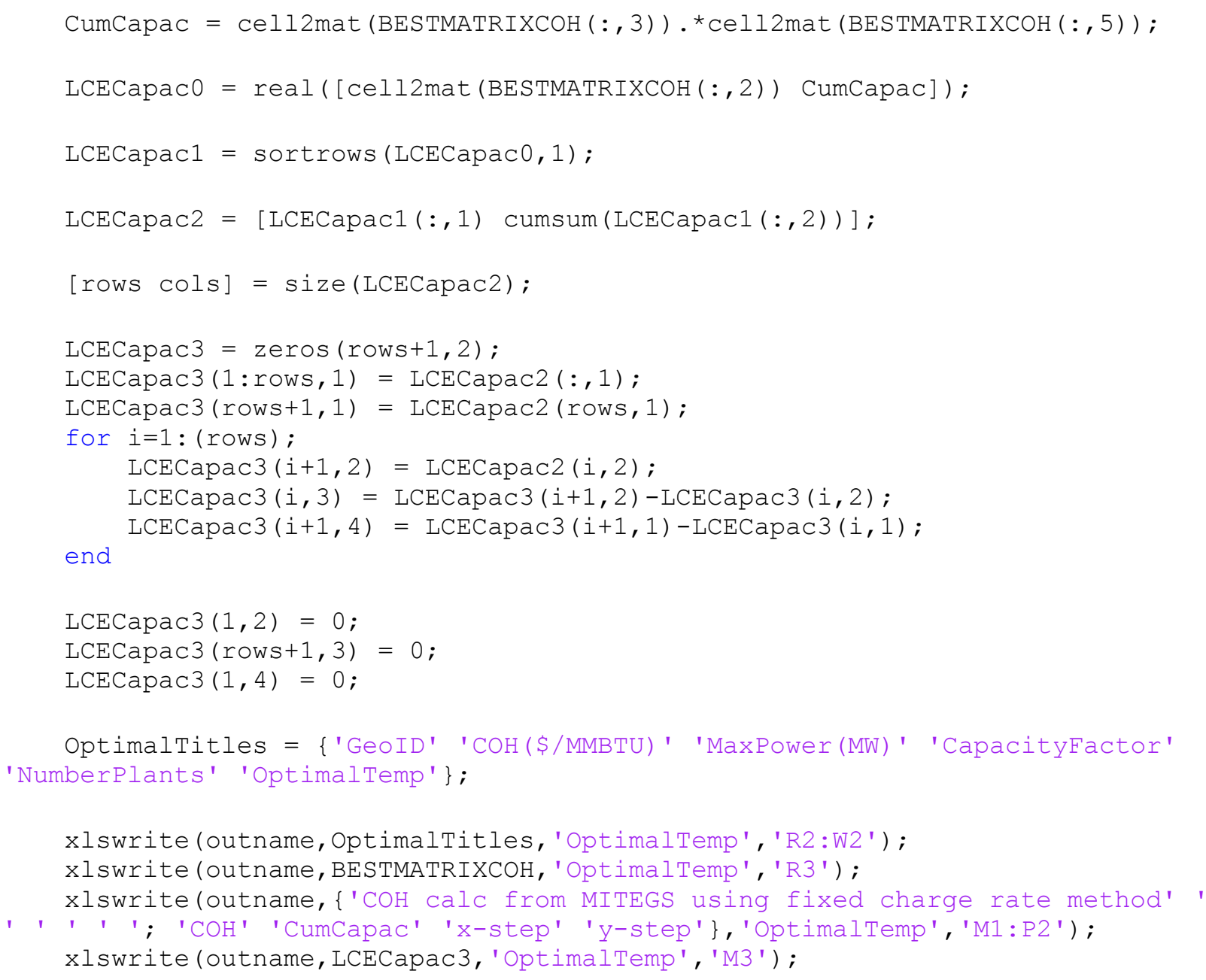




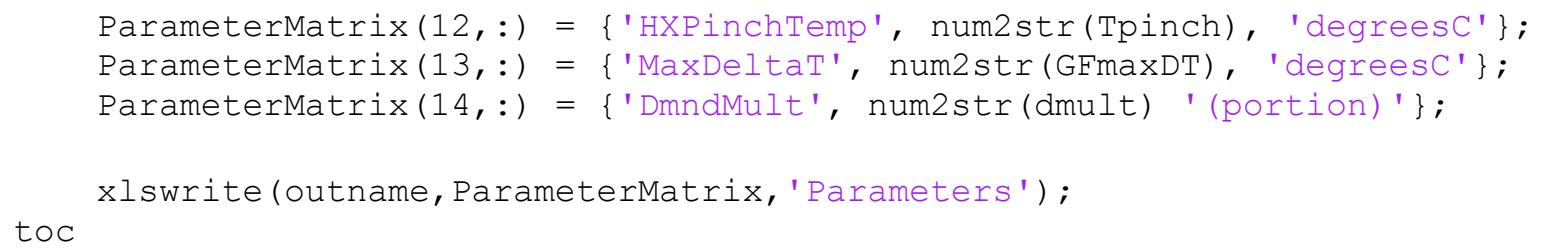

\section{Appendix C - Demand Function File}

The following MATLAB code is used to generate the annual temperature and heating demand profiles at each census "place" in the dataset.

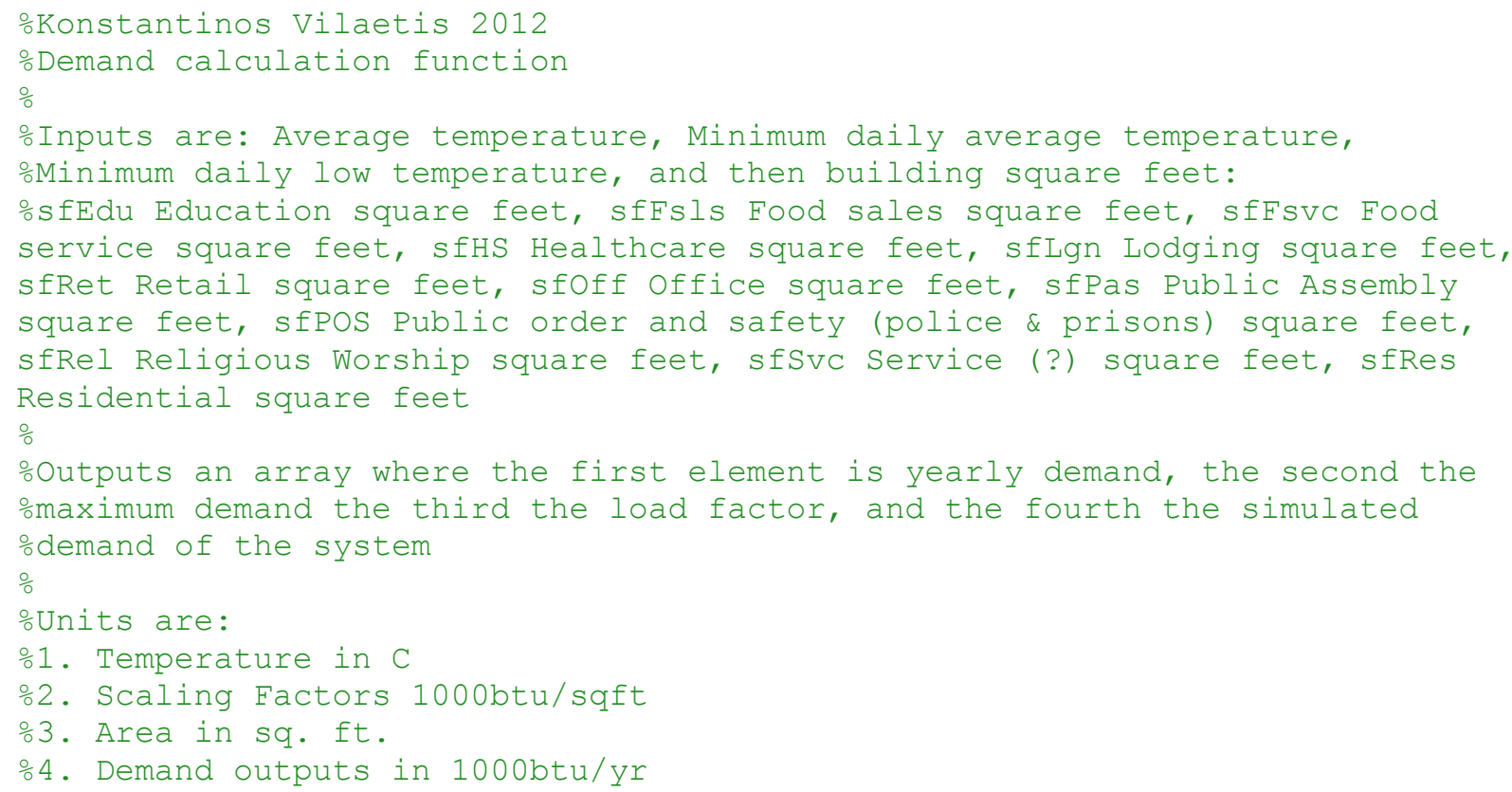




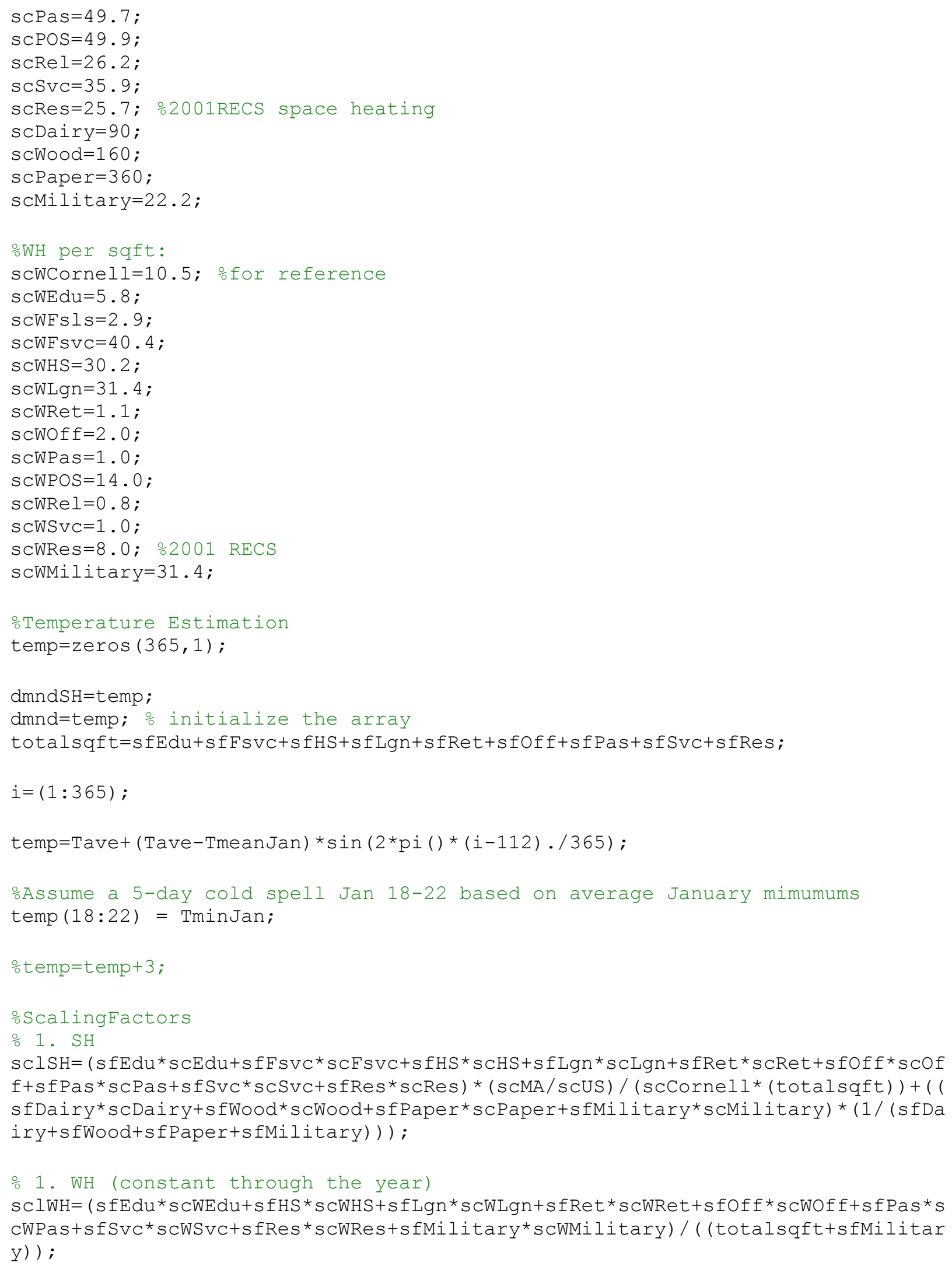




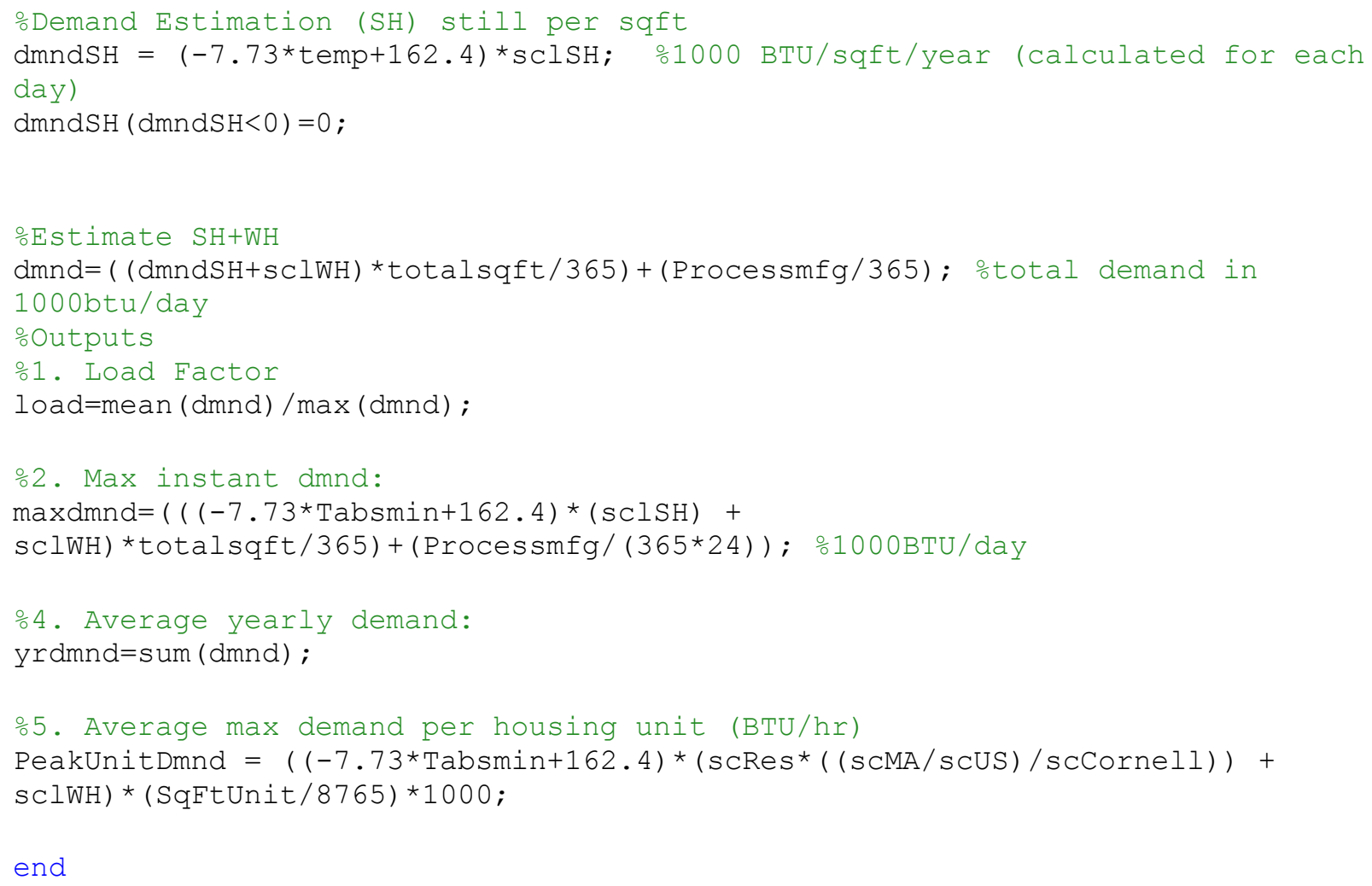




\section{Appendix D - DistCost File}

This section contains MATLAB code used to estimate the size and cost of distribution piping and other surface equipment.

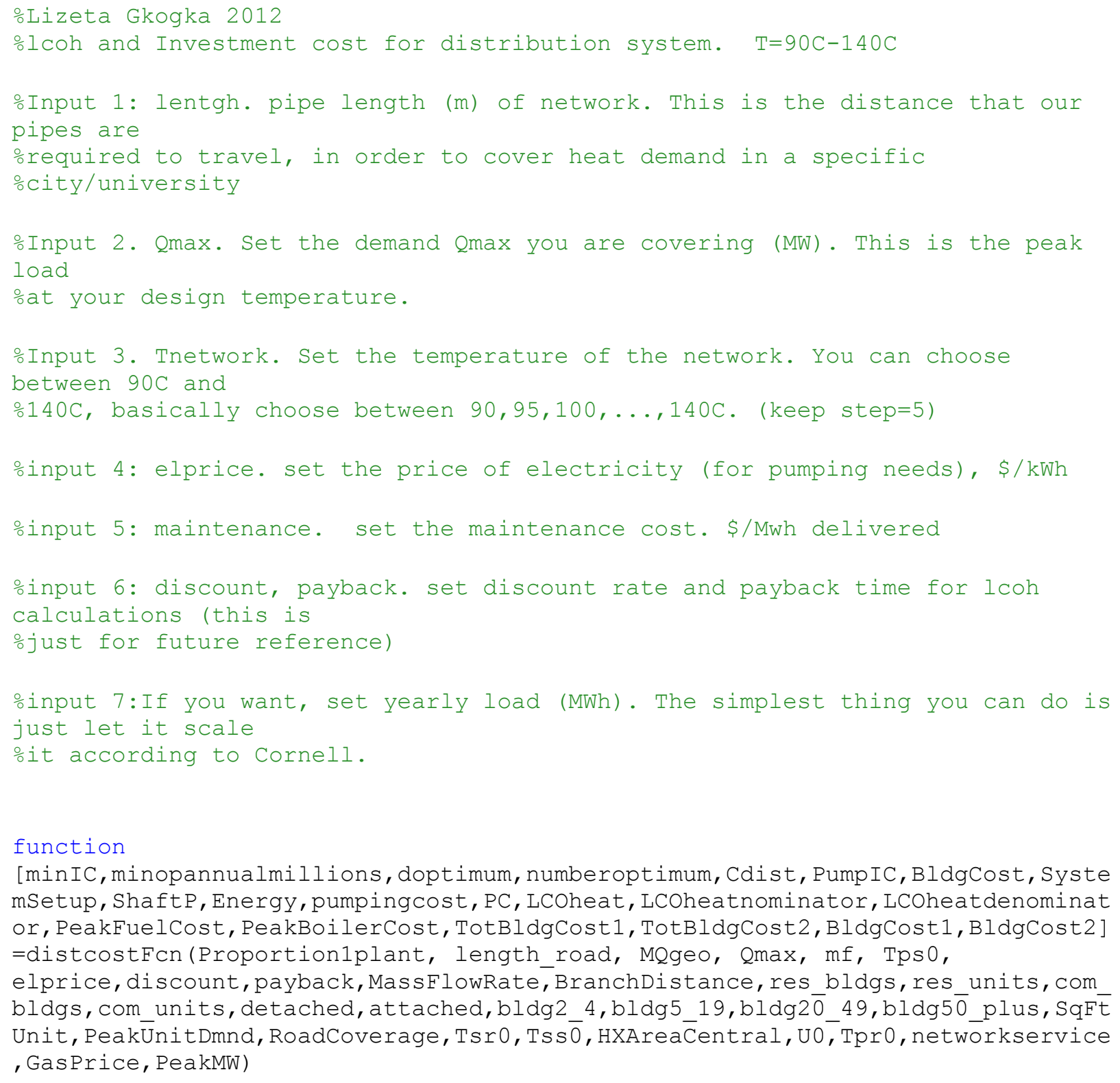




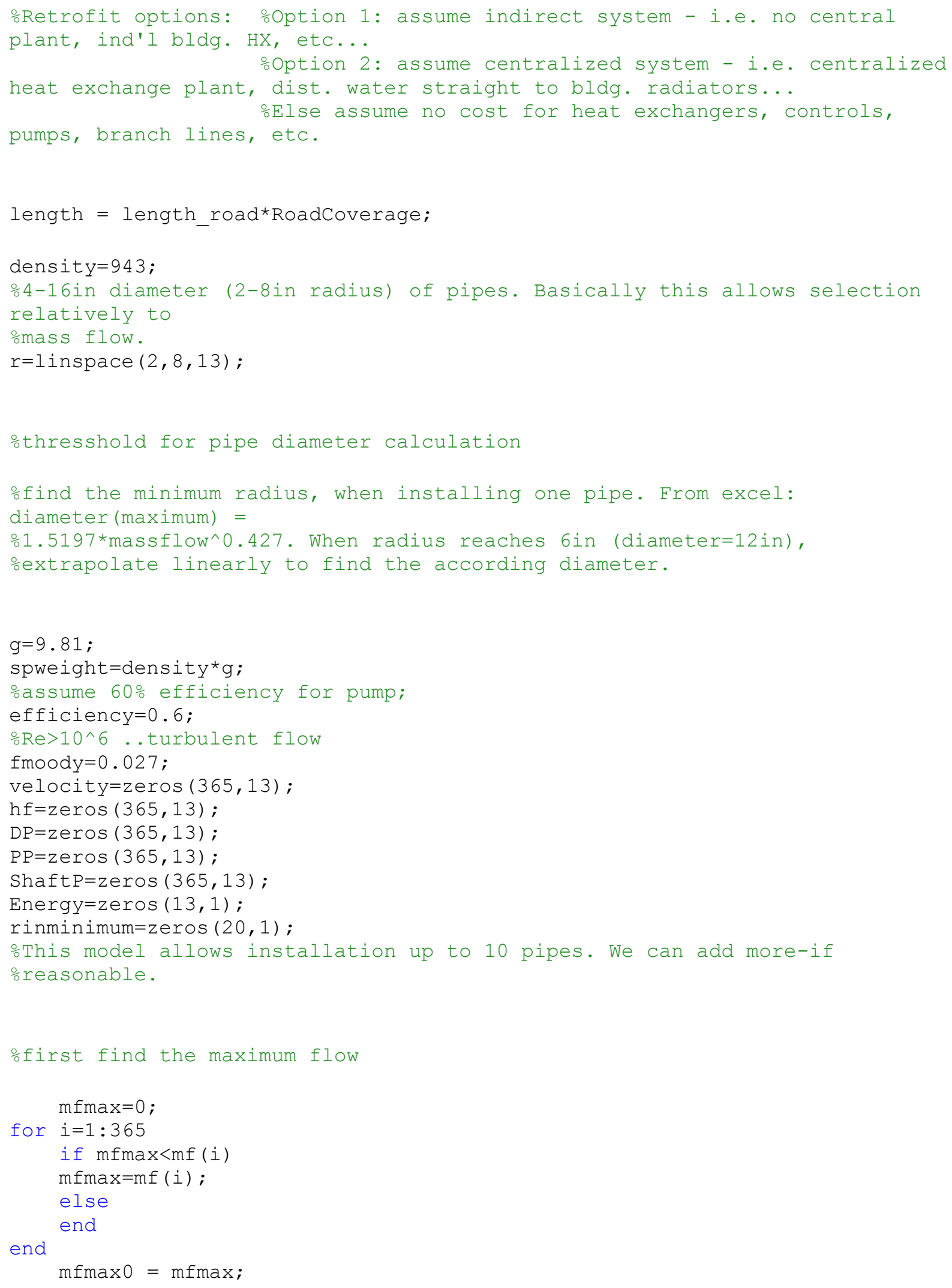




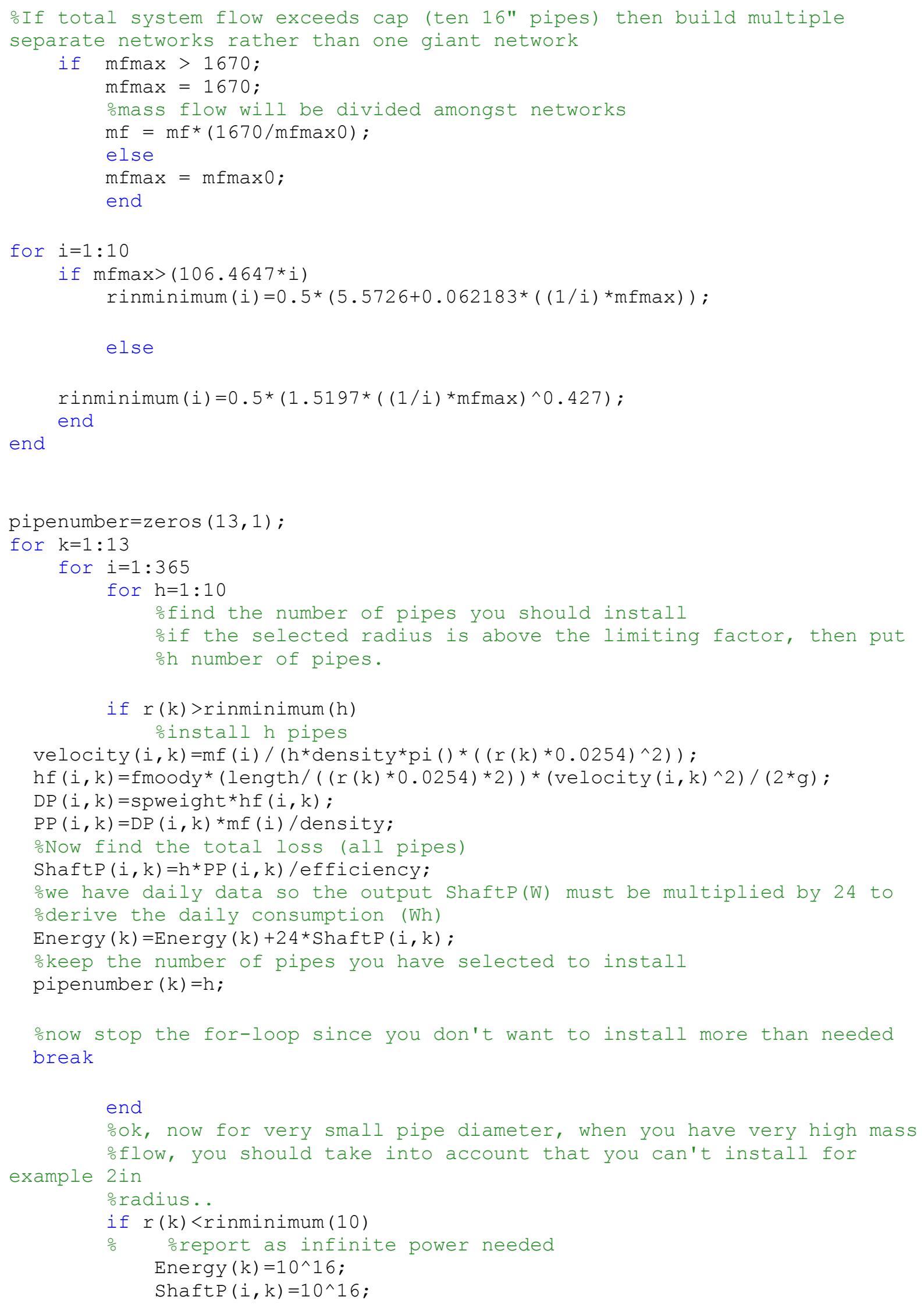




end
end

MWH=Energy $/ 1000000$;

ototal pumping cost

pumpingcost $=\mathrm{MWH}^{\star}$ elprice ${ }^{*} 1000$;

$\mathrm{PC}=\operatorname{zeros}(1,13)$;

for $j=1: 13$

PC $(j)=$ pumpingcost $(j) /$ MQgeo ;

end

opumping investment cost

oassume that cost varies proportionally to power output ( $\mathrm{kW}$ )

ofor $800 \mathrm{~kW}$ purchased cost 30,000\$==>with f=3.5: $120000 \$$. No further data for opumping cost function with capacity in Perry's, so assume linear scaling up/down

ofind maximum power needed by the pump.

Shaftmax=zeros $(13,1)$;

Shaftmax $=\max (\operatorname{ShaftP}(:, 1: 13))$;

Pneeded=Shaftmax;

ocalculate investment cost of pump according to its capacity. scale up/down. PumpIC $=($ Pneeded $/ 800000) * 120000$;

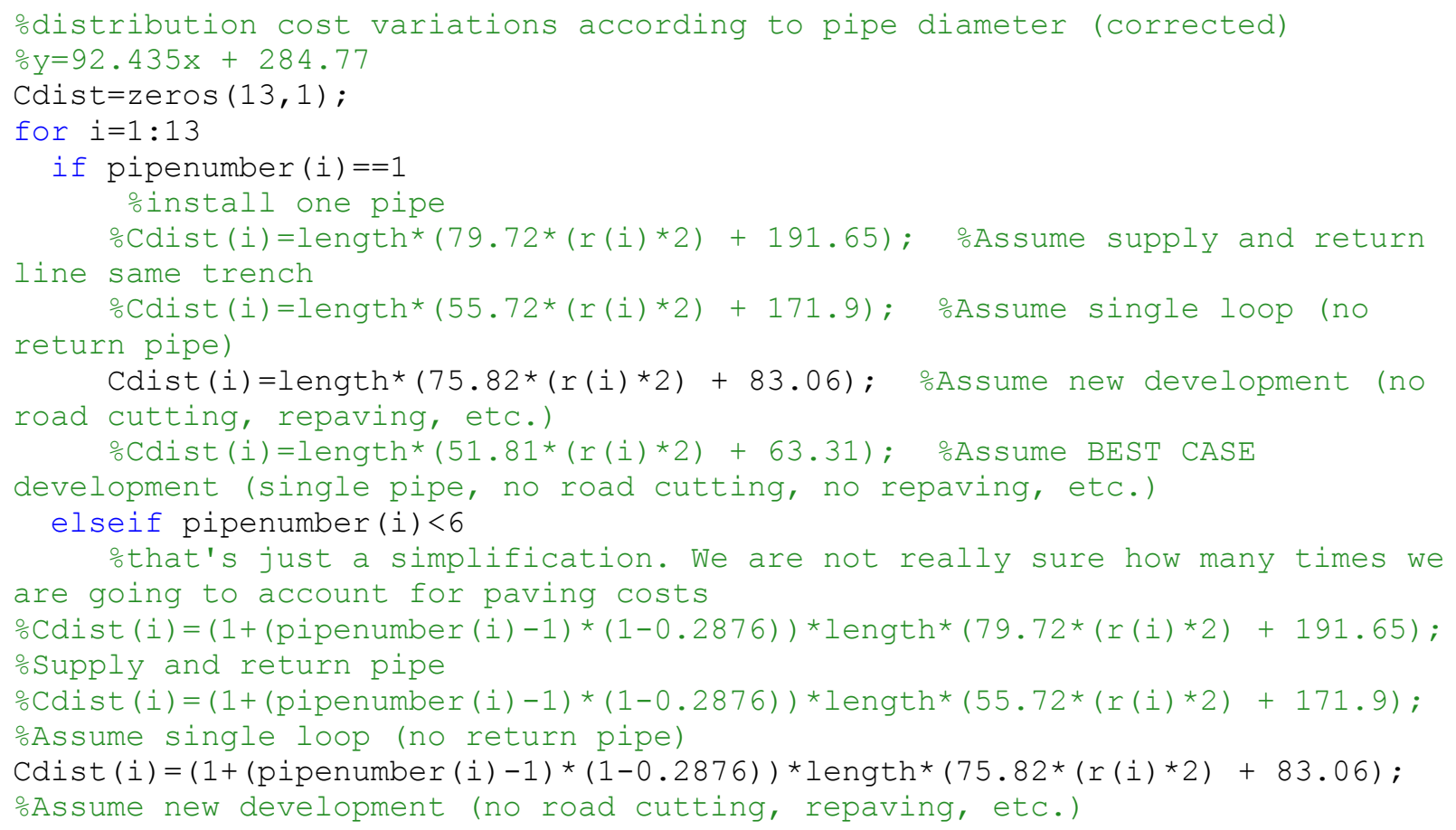




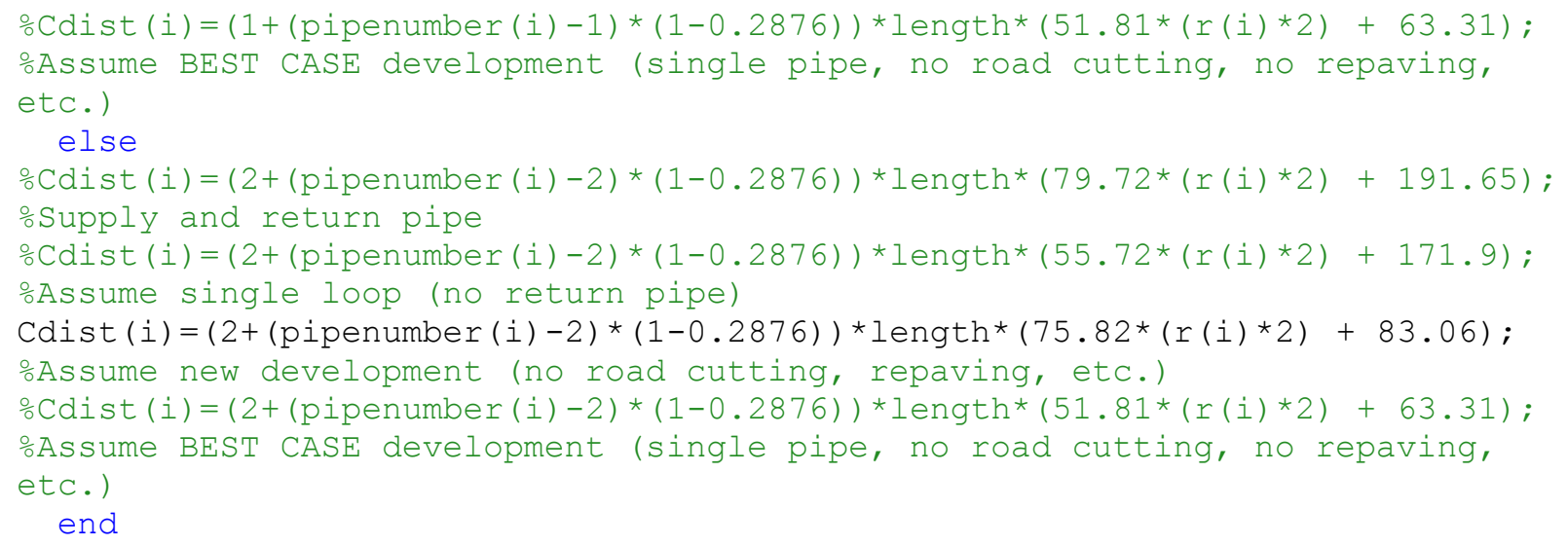




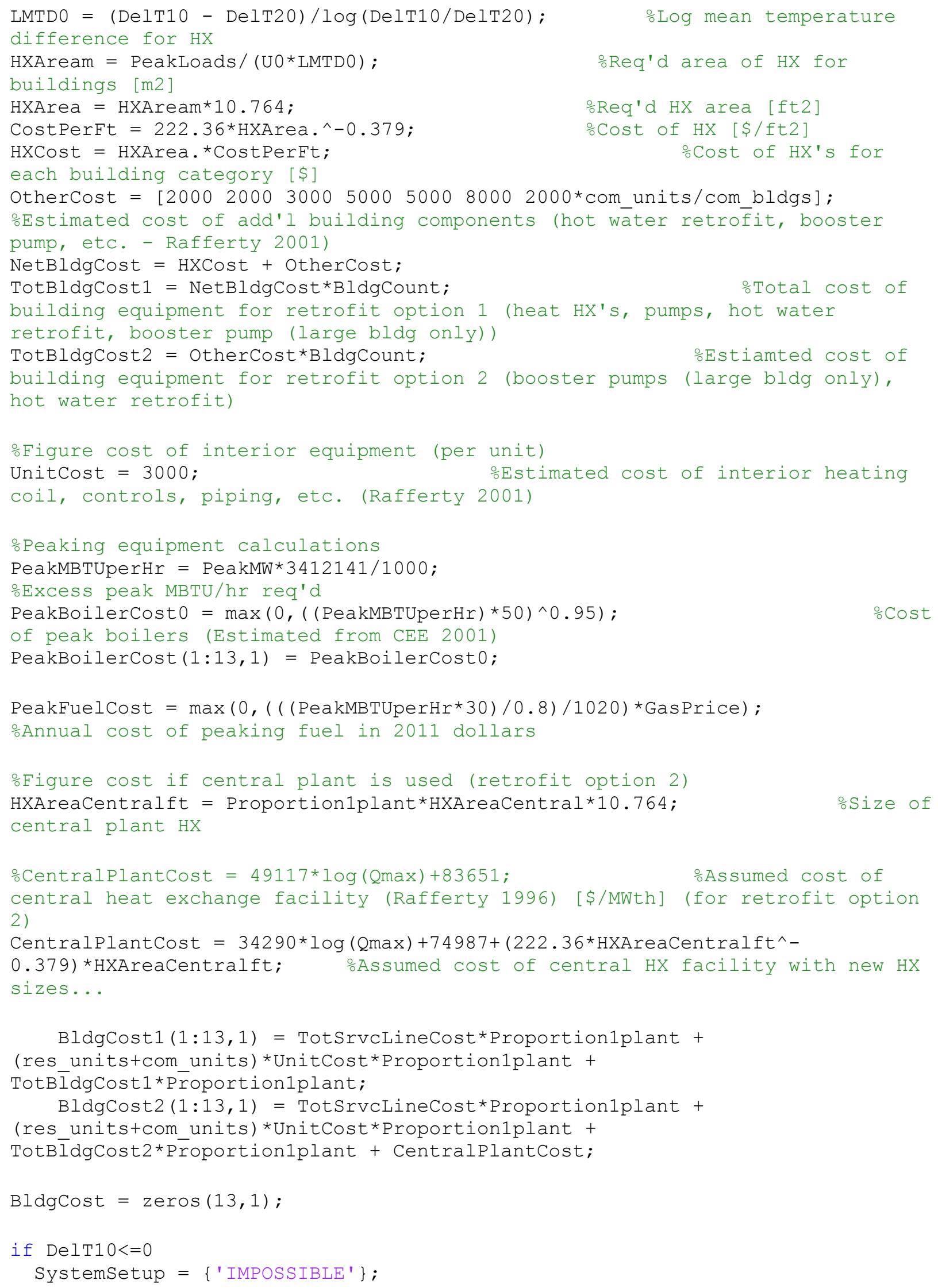




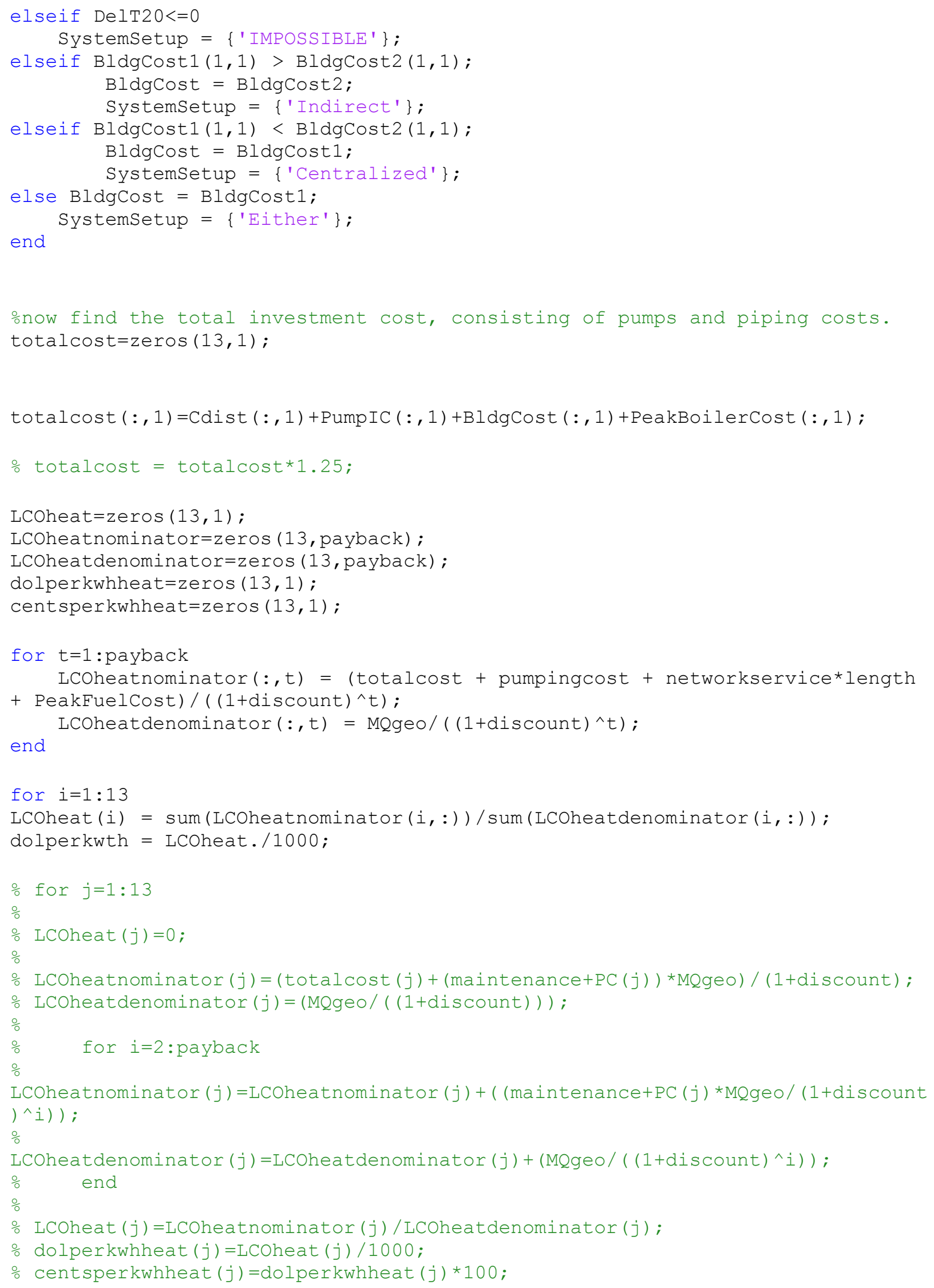




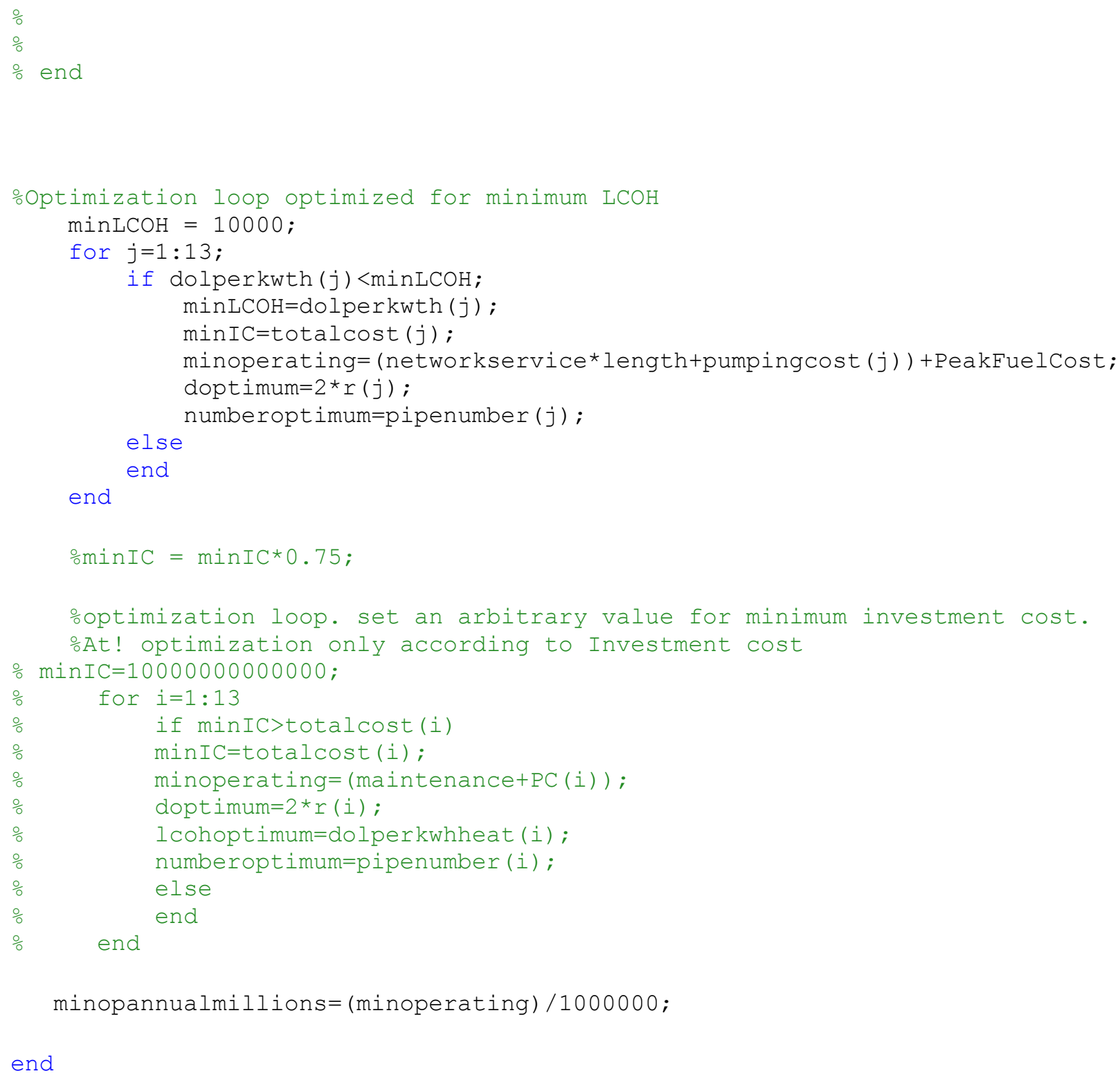




\section{Appendix E - Flow Calculation File}

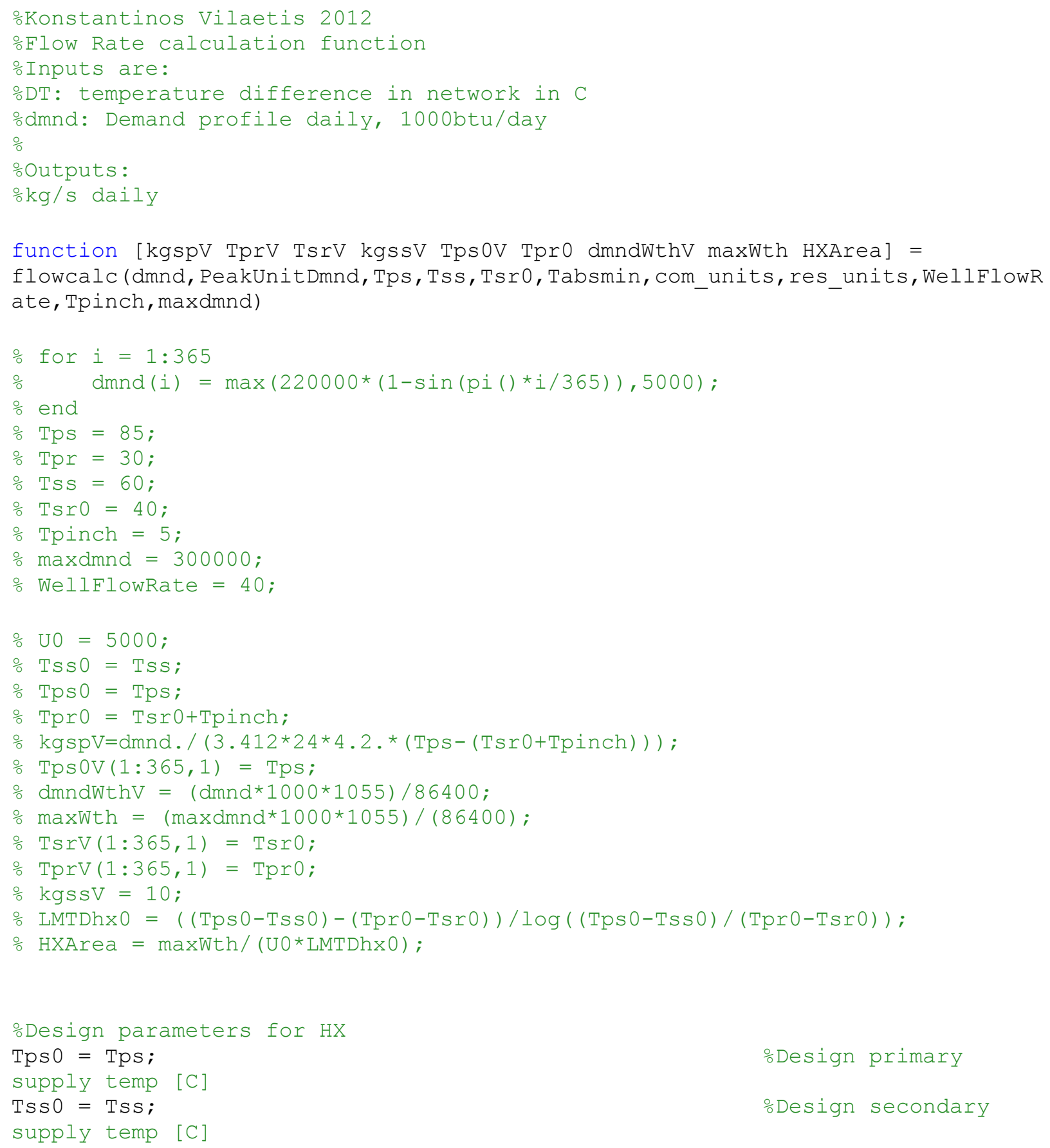




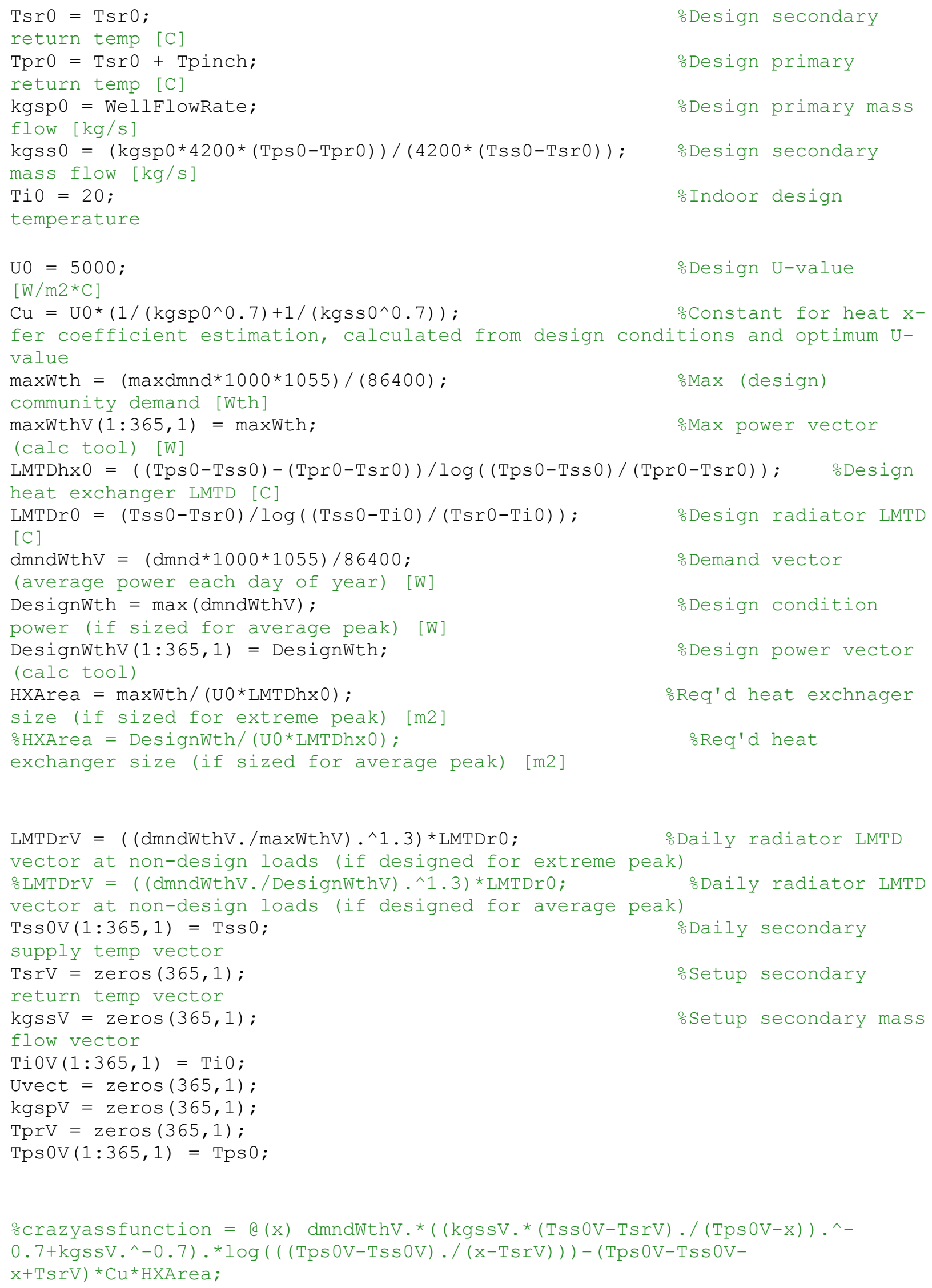




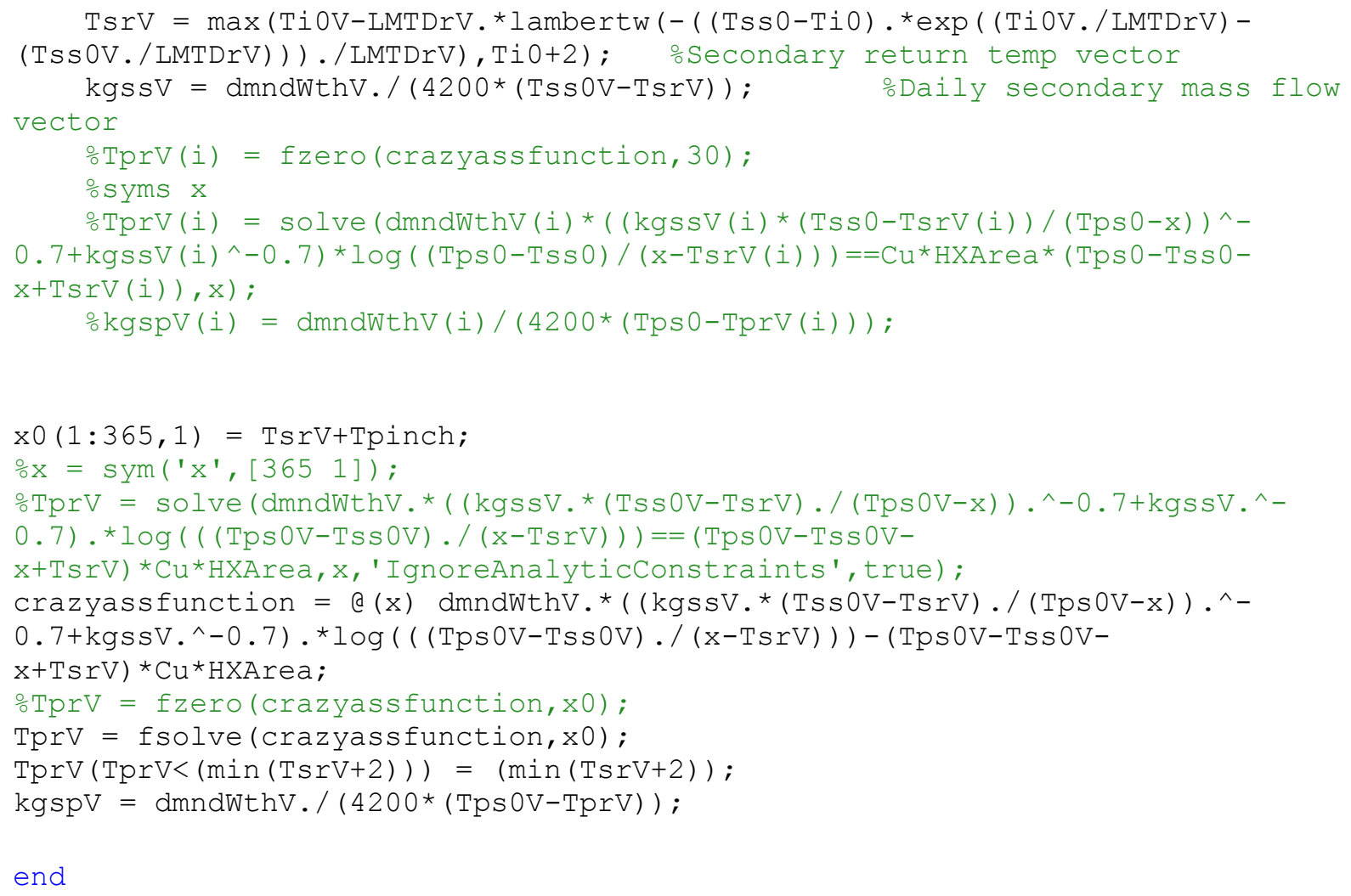




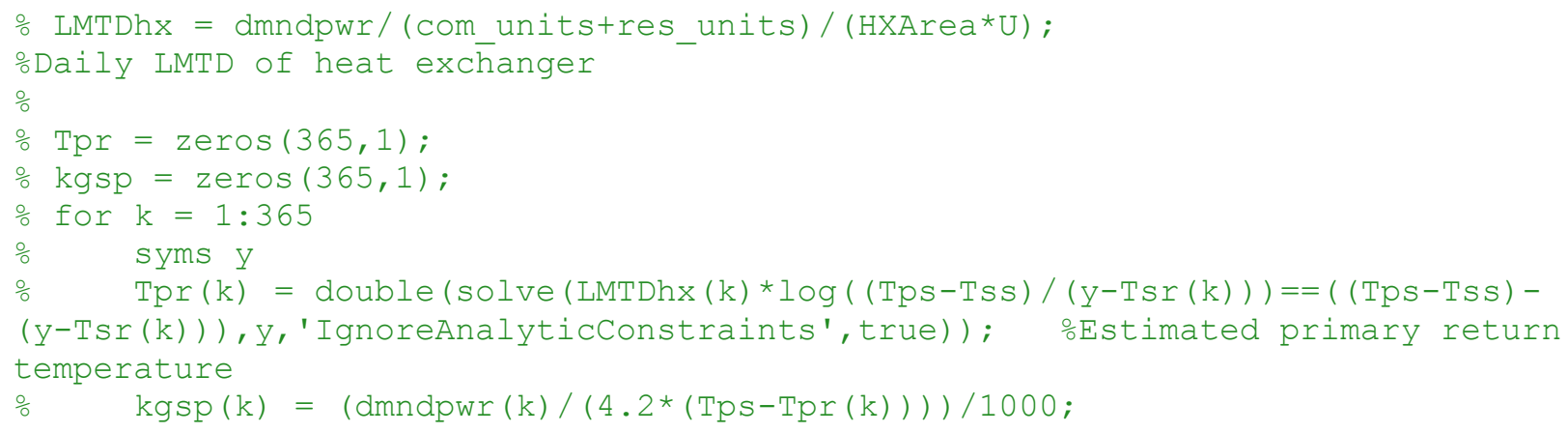




\section{Appendix F - Make Input File}

This section contains the MATLAB code used to generate the input file responsible for passing all variables from the MATLAB shell to GEOPHIRES.

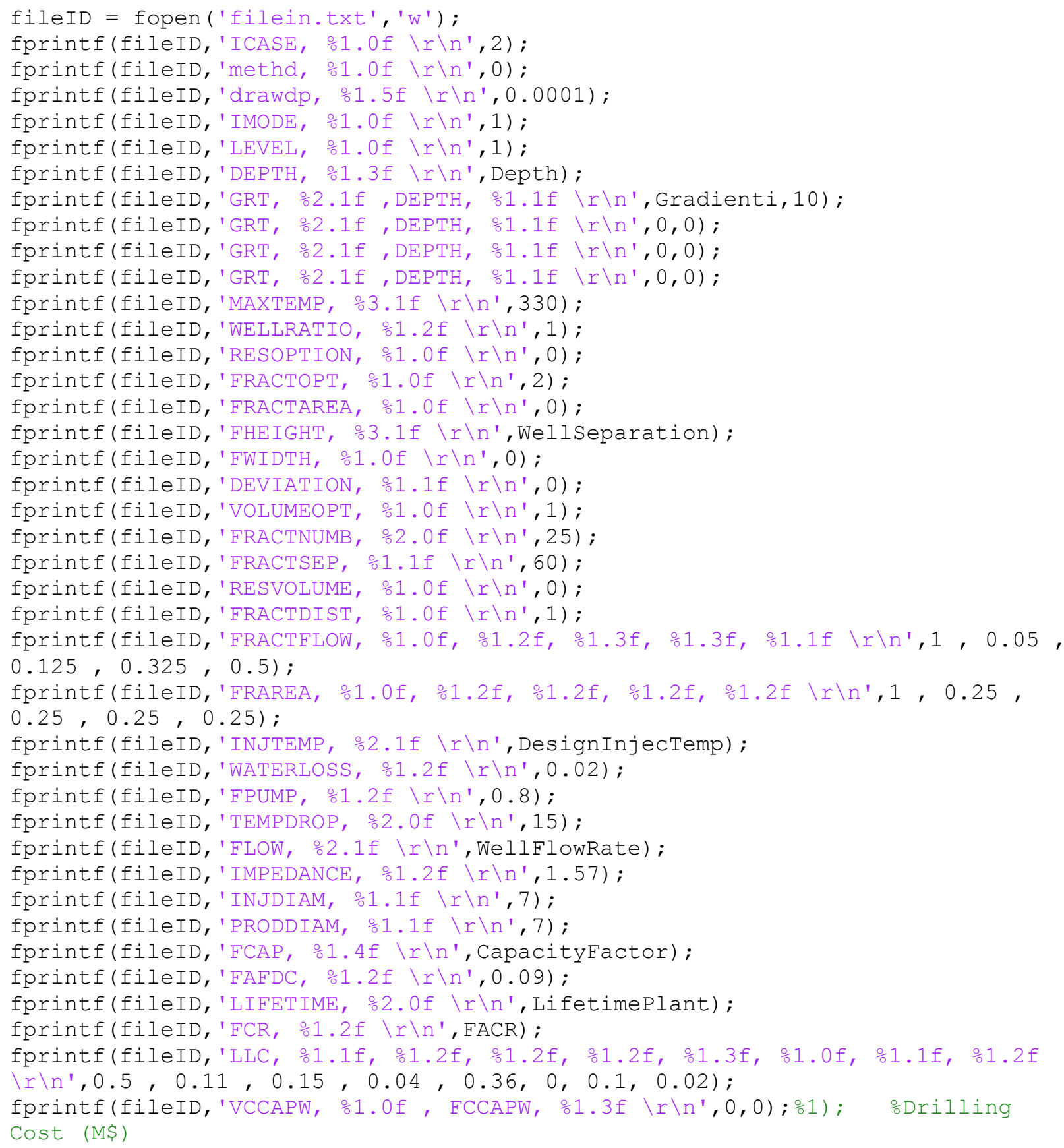




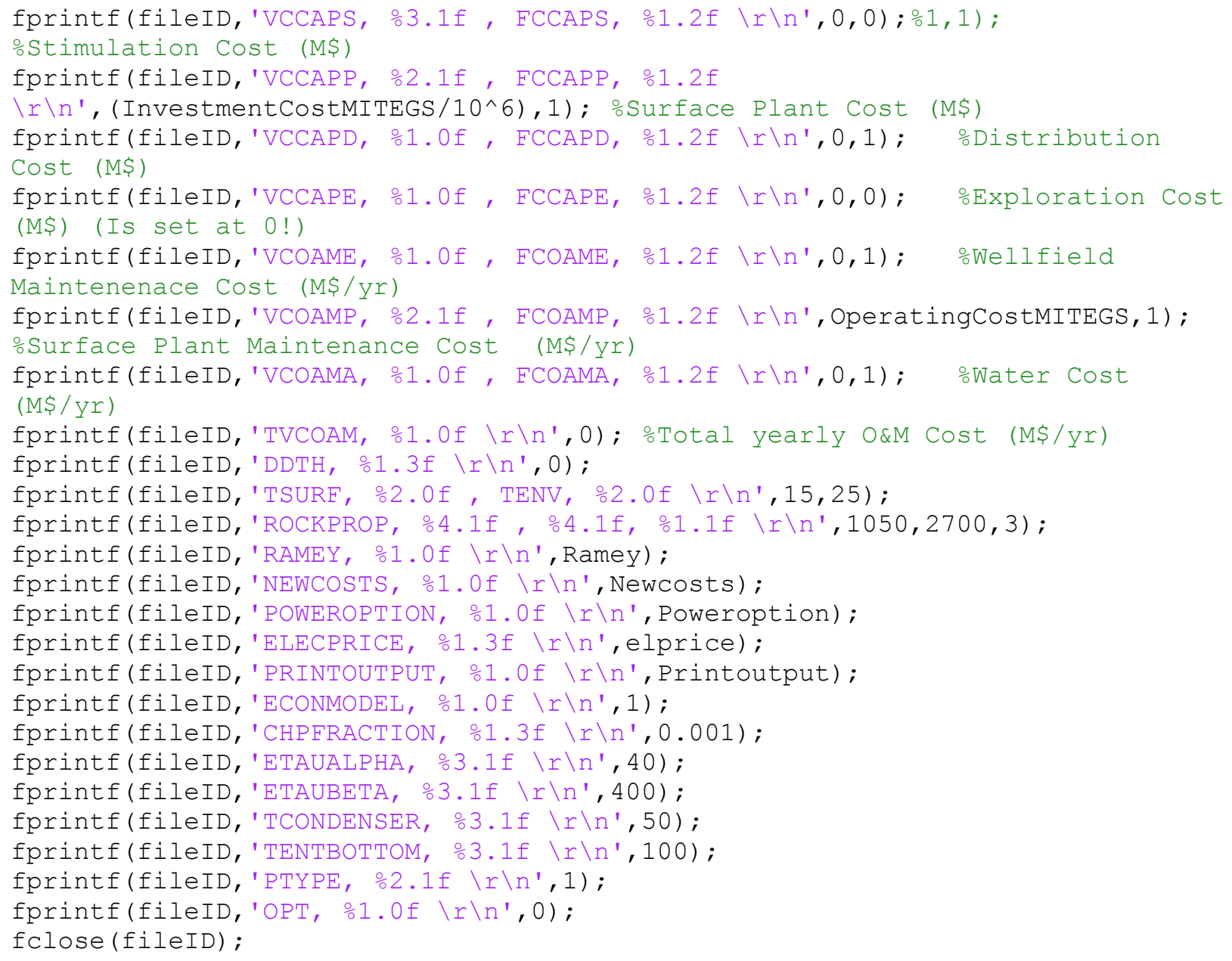


